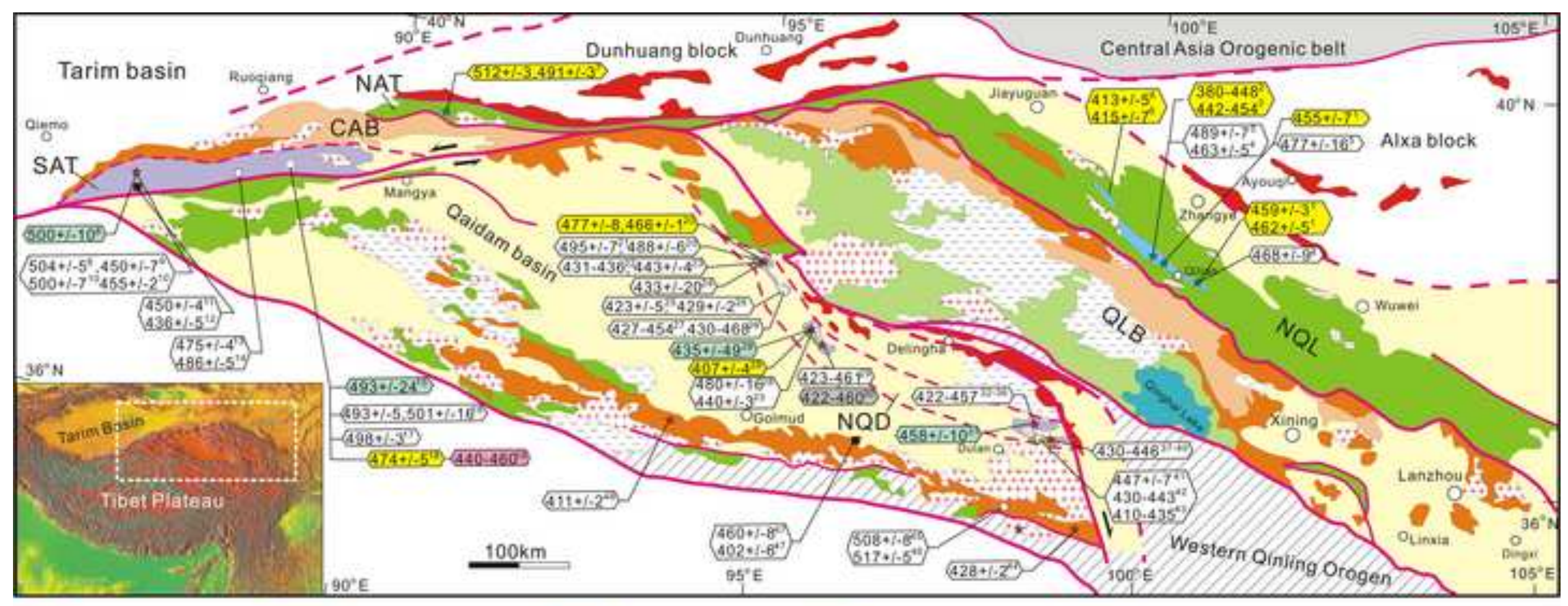

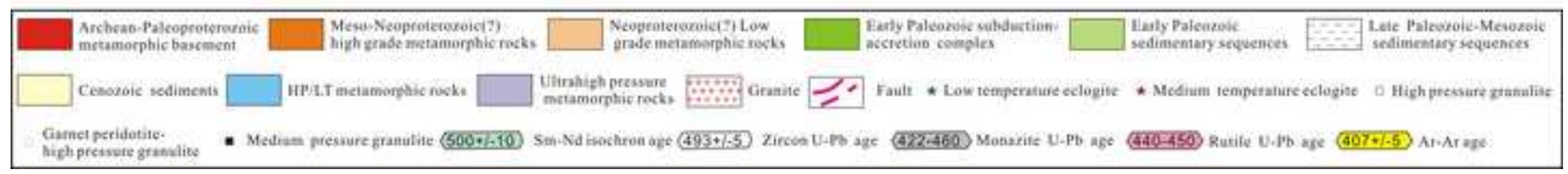




\title{
Early Paleozoic polyphase metamorphism in northern Tibet, China
}

\begin{abstract}
The Altun-Qilian-Kunlun orogenic system in the northern Tibetan Plateau is considered as the northernmost orogenic collage of the proto-Tethyan domain. Early Paleozoic polyphase tectonothermal events related to the subduction of the proto-Tethyan ocean and subsequent collisional orogeny produced two dominant metamorphic belts: the North Altun (NAT)-North Qilian (NQL) HP/LT metamorphic belt, and south Altun (SAT)-north Qaidam (NQD) UHP metamorphic belt. The NAT -NQL HP/LT metamorphic belt mainly consists of blueschist, eclogite and HP metasediments. Eclogites record metamorphic conditions of $420-550{ }^{\circ} \mathrm{C}$ and $21-25$ Kbar, at 510-460 Ma. The HP/LT metamorphic belt is associated with ophiolite, subduction-accretion complex, and arc magmatic rocks, suggesting that the NAT-NQL is a typical early Paleozoic accretionary orogenic belt. In contrast, the SAT-NQD UHP metamorphic belt is characterized by eclogite and garnet peridotite enclosed within continental orthogneiss and paragneiss. These rocks record UHP metamorphism at $\mathrm{T}>700{ }^{\circ} \mathrm{C}$ and $\mathrm{P}>27 \mathrm{Kbar}$. Geochronology suggests that the UHP metamorphism occurred at 500-423 Ma, and eclogite protolith ages of 850-750 Ma suggests protoliths are related to Neoproterozic continental rifting. Field relationships, petrology and geochronology suggest that the SAT-NQD UHP metamorphic belt resulted from the deep subduction of continental crust. Moreover, in the SAT-NQD
\end{abstract}


UHP metamorphic belt, two types of HP granulites have been recognized. The first type of HP granulite was formed by overprinting of eclogites during exhumation. The second type of HP granulite has a single metamorphic history and similar age to that of UHP eclogite. Penecontemporaneous metamorphic ages but different geothermal gradients between HP granulites and related UHP eclogite define a possible paired metamorphic belt, which may be considered to be a diagnostic characteristic of collisional orogens. High grade metamorphic rocks in the SAT-NQD commonly record Barrovian type metamorphism, although it remains unclear whether or not all of these rocks have an earlier (U)HP metamorphic history. The low-medium-P Barrovian metamorphism and associated magmatism are about 20-50 Ma later than UHP metamorphism. Newly recognized eclogites in the northern part of the East Kunlun Mountains, to the south of Qaidam basin, have a similar field relationship (enclosed in continental gneiss) and mineral assemblage to the NQD eclogites, and a similar or slightly younger metamorphic age (410-430 Ma). The occurrence of similar continental type eclogites on two sides of the Qaidam basin makes it necessary to reconsider the nature of the Qaidam block. The polyphase metamorphism in northern Tibet can be linked to accretion and collisional orogenesis related to the evolution of Prototethys through the early Paleozoic.

Key words: Early Paleozoic, Northern Tibet, polyphase metamorphism, accretion, collision, Prototethys 


\section{Introduction}

The (Qinghai-) Tibetan Plateau generally consists of three huge orogenic 
Tibet experienced a typical accretionary orogeny characterized by the development of an evolving arc-accretion complex growing southward along the margin of the Tarim and north China Craton during Paleozoic time (Sengör, 1993, Sengör and Natal'in, 1996; Gehrels et al., 2003a and b; Yin et al., 2007; Xiao et al., 2009). Therefore, Early Paleozoic accretion vs. collision in north Tibet remains a controversial issue.

In the past decade, the early Paleozoic metamorphism in northern Tibet has become a major research topic since ultrahigh-pressure (UHP) eclogite and associated metamorphic rocks have been found (Yang J.S. et al., 1998, 2001; Song et al., 2003, 2004, 2005; Zhang J. et al., 2001a; 2002; Liu et al., 1996, 2002; Yang J.J., 1994). Abundant studies have revealed various metamorphic rocks including high-pressure (HP)/low-temperature (LT) metamorphic rocks, UHP metamorphic rocks, HP granulites and low-medium pressure metamorphic rocks, which record a polyphase tectonometamorphic evolution in northern Tibet (Yang J.S. et al., 2003; Song et al., 2005, 2006, 2009, 2013, 2014a; Zhang J. et al., 2005a, 2006, 2009a, 2010, 2014; Liu et al., 2012; Yang J.J., 2008; Zhang G., 2013, Zhang C., 2011, 2015; Yu et al., 2011, 2012, 2014, 2015). These metamorphic rocks hold important insights for early Paleozoic orogenesis in northern Tibet.

In this contribution, based on published and our new data, we present a synthesis of the geological, petrological, chronological studies of early Paleozoic metamorphic rocks in northern Tibet. These data allow a relatively detailed insight into the polyphase tectonometamorphic history and associated orogenesis including subduction-accretion, collision, and orogenic collapse in northern Tibet during the early Paleozoic.

\section{Tectonic outline of early Paleozoic orogenic systems in northern} Tibet

The early Paleozoic Altun-Qilian-Kunlun (AQK) orogenic system in northern 
119 Tibet extends in a WNW-ESE direction for $\sim 1000 \mathrm{~km}$, and is bounded to the north by

120 the Alxa block and to the south by the late Paleozoic-Mesozoic South

121 Kunlun-Qiangtang-Ganze orogenic system (Fig. 1). This orogenic system was cut by

122 the Altyn Tagh fault. Abundant evidence supports the interpretation that the main geological units in the Altun Mountains are the western extension of those in the

124 Qilian-North Qaidam Mountains. Therefore, on the basis of geologic mapping and lithotectonic characteristics, the AQK orogenic system can be subdivided into four tectonic units: the North Altun-North Qilian subduction-accretion complex, the Qilian-Central Altun micro-continental block, the North Qaidam-South Altun subduction-collision complex, and the Qaidam-North Kunlun block (Fig. 1).

The North Altun (NAT)-North Qilian (NQL) subduction-accretion complex is an elongate, WNW-ESE trending belt that lies between the Alxa block-Dunhuang block to the north and the Qilian (QLB)-Central Altun (CAB) microcontinental block to the south (Fig. 1). The Altyn Tagh fault separates this belt into two parts: the NAT and the NQL. The NAT subduction-accretion complex, which is discontinuously exposed along the northeastern part of the Altyn Tagh from Hongliugou to Lapeiquan, consists mainly of clastic and volcanic rocks with rare mafic and ultramafic intrusive rocks. Well-preserved pillow lavas and serpentinized ultramafic rocks suggest that these rocks are part of an ophiolite suite. A HP/LT metamorphic terrane, characterized by blueschist and eclogite, occurs as a tectonic block or slab in the subduction-accretion complex. ${ }^{40} \mathrm{Ar} /{ }^{39} \mathrm{Ar}$ dating of eclogite and blueschist suggests that HP/LT metamorphism occurred at 490-512 Ma (Zhang J. et al., 2007a, see below). The NQL subduction-accretion complex consists of ophiolitic mélanges, HP/LT blueschists and eclogites, island-arc volcanic rocks with granite plutons, and Silurian flysch formations, which are unconformably covered by Devonian molasses and Carboniferous to Triassic sedimentary cover sequences (Xu et al., 1994; Zhang J. et al., 1998, 2012). The NQL is regarded as the product of subduction of an Early Paleozoic ocean plate between the Alxa block and Qilian block (Xiao et al., 1978; Xu et al., 1994; Zhang J. et al., 1998, 2012; Xia et al., 2003, Ker et al., 2015, described 148 below). 
The CAB-QLB is located between the NAT-NQL subduction-accretion complex and the North Qaidam-South Altun subduction-collision complex. The CAB consists of the Altun Group and Tashidaban (or Jinyanshan) Group. The Altun Group is comprised of amphibolite-facies quartzo-feldspathic gneisses, pelitic gneisses, marbles, and amphibolites, and was considered to represent Precambrian craton basement rocks of lower Proterozoic-Archean age (BGMX, 1993). However, recent radiometric data demonstrate that the Altun Group formed at 800-1000 Ma (e.g., Wan et al., 2001; Gehrels et al., 2003a; Zhang J. et al., 2011). The Tashidaban Group is dominated by mid- to upper Proterozoic metasedimentes that consist of thick carbonate-rich continental margin sequences containing variable amounts of volcanics and clastics.

The QLB, located between the NQL subduction-accretion complex and the NQD subduction-collision complex, consists mainly of Precambrian basement overlain by Neoproterozoic to Mesozoic sedimentary sequences. From west to east, the lower part of the basement is known as the (a) Yemananshan Group, (b) the Huangyuan and Hualong Groups and (c) the Maxianshan Group. The basement consists of paragneiss, granitic gneiss, marble, amphibolite and localized granulite. Granitic gneisses yield protolith ages of 950-870 Ma (Wan et al., 2001; Xu et al., 2007; Tung et al., 2007, 2012, 2013; Yu et al., 2013). The Precambrian basement rocks were partly reworked during early Paleozoic orogeny. The QLB was previously considered to be a fragment rifted from the North China craton, but recent geochemical and geochronologic data demonstrate that the metamorphic basement has a close affinity to the Yangtze craton (South China block; e.g. Wan et al., 2001, 2006; Tung et al., 2007) or Gondwana supercontinent (Tung et al., 2012, 2013; Yu et al., 2013). However, along the northern margin of the Qilian block, several Alaska-type, zoned mafic complexes and "I" type granites with an age of ca. $500 \mathrm{Ma}$ (Zhang Q. et al., 1997; Wu et al., 2009; Huang et al., 2015; Zhang J. et al., unpublished data) have geological and geochemical features that indicate an origin related to the southward subduction of the north Qilian ocean (Gehrels et al., 2003a, b; Xiao et al., 2009). Moreover, a microcontinent fragment, called the Quanji massif (or Oulongbuluke microcontinent), is recognized in the 
southern margin of the Qilian block (Lu et al., 2008; Gong et al., 2012; Chen et al., 2013; Liao et al., 2014). Compared to the other parts of the Qilian block, the Quanji massif has older metamorphic basement composed of Paleoproterozoic granitic gneisses, paragneisses, marbles and minor mafic granulites (e.g. Zhang J. et al., 2001b; Lu et al., 2008; Chen et al., 2013; Wang et al., 2015). The basement rocks are unconformably covered by Neoproterozoic to Mesozoic strata. The relation of the Quanji massif to other parts of the Qilian block remains unclear and further work is necessary.

The South Altun (SAT)-North Qaidam (NQD) subduction-collision complex, located between the CAB-QLB and Qaidam Block, consists mainly of para- and orthogneisses enclosing blocks of eclogite, garnet peridotite and mafic granulite. They thrust over, or are overlain by, lower Paleozoic volcanic and sedimentary rocks, and are intruded by granites. Eclogites and garnet peridotites in the SAT and NQD record UHP metamorphic conditions, and coesite-bearing paragneisses are also recognized in the Dulan area of the eastern NQD (Fig. 1; Yang et al., 2002; Song et al., 2003, 2005; Liu et al., 2002; Zhang J. et al., 2002, 2009b, 2010; Zhang G. et al, 2009a,b). Zircon $\mathrm{U}-\mathrm{Pb}$ ages and $\mathrm{Sm}-\mathrm{Nd}$ from paragneiss, eclogite, and peridotite of the SAT-NQD have been interpreted to record varying peak metamorphism between 423-500 Ma (Yang et al., 2001, 2002; Song et al., 2003, 2005, 2006; Zhang J. et al., 2001a, 2005a, 2008, 2010; Mattinson et al., 2006b, 2009; see below).

Although the Qaidam basin is covered by Cenozoic sediments, its basement has been considered as part of a rigid, stable craton consisting of Precambrian metamorphic basement coherent with high grade metamorphic rocks in the north Kunlun (NKL) (BGMQ, 1991). The metamorphic basement of the NKL consists of the Paleo- and Mesoproterozoic Jinshuikou Group, intruded by Neoproterozoic granites (e.g. Chen et al., 2006; Lu et al., 2006; He et al., 2015). Some data suggest that the Jinshuikou Group experienced early Paleozoic amphibolite-granulite facies metamorphic overprinting (Chen et al., 2006, 2007; Zhang J. et al., 2003). Recently, eclogite and retrogressed eclogite have been recognized in the high grade metamorphic rocks in the western and eastern NKL, and preliminary geochronology 
yielded metamorphic ages of 411-430 Ma (Meng et al., 2013, Qi et al., 2014). These data imply that the metamorphic basement of the Qaidam-NKL block witnessed early Paleozoic orogeny (see below).

\section{HP/LT metamorphism related to oceanic subduction}

In northern Tibet, HP/LT metamorphic rocks are mainly distributed in two areas-North Qilian (NQL) and North Altun (NAT). For the two areas, we review key rock types, mineral assemblages, $\mathrm{P}-\mathrm{T}$ estimates, and geochronology where available. Based on these data, we will then compare the two areas in order to identify common metamorphic and tectonic relations.

\subsection{NAT HP/LT metamorphic rocks}

The NAT HP/LT metamorphic rocks occur as a tectonic block or slab in the subduction-accretion complex (Zhang J. et al., 2005b, Fig. 2A). The HP/LT slab is elongate, $2-5 \mathrm{~km}$ wide and $40 \mathrm{~km}$ long, and is separated by a shear zone (fault) from ophioltic mélange (Fig. 2). HP/LT rock types include garnet- and chloritoid-bearing mica schist (metapelite), quartz-mica schist, calc-schist, and metabasite composed of eclogites and blueschists (Zhang J. et al., 2005b). Blueschist and eclogite pods occur within pelitic schist and calc-schist. Most eclogite and blueschist pods are elliptical and range in size from $\sim 10 \mathrm{~cm}$ to $\sim 10 \mathrm{~m}$ (Fig. 3). The long axis of the pods is parallel to the regional foliation. Some eclogite pods are characterized by folded, millimeter-scale alternating layers of eclogite and calc-schist (Fig. 3c).

Eclogite consists of garnet, omphacite, phengite and quartz with varying amounts of glaucophane, $\mathrm{Ca}-\mathrm{Na}$ amphibole (barroisite), epidote (zoisite or clinozoisite), paragonite, chlorite, albite, carbonate and titanite. The alignment of omphacite, minor phengite, paragonite and quartz defines a foliation in the matrix as well as within the garnet (Fig. 4a). Some eclogites preserved relicts of lawsonite eclogite-facies 
assemblages within garnet (Zhang and Meng, 2006). Blueschist is characterized by idioblastic garnets in a fine-grained matrix consisting of oriented glaucophane, barroisite, phengite, paragonite and quartz. The assemblage Grt $+\mathrm{Gl}+\mathrm{Phn}+\mathrm{Pg}+$ Qtz is volumetrically dominant, and is interpreted to represent the peak metamorphic assemblage. Chlorite and epidote occur as porphyroblasts, contain inclusions of relict glaucophane, and cut the foliation (Fig. 4b). Metapelite contains a peak-stage assemblage of Grt $+\mathrm{Cld}+\mathrm{Phn}+\mathrm{Pg}+\mathrm{Qtz}$ in addition to retrograde albite + chlorite and accessory epidote, apatite, tourmaline and hematite (Fig. 4c and d). Oriented phengite and chloritoid define a foliation. In strongly overprinted domains, garnet is totally replaced by chlorite and hematite.

P-T estimates yield peak conditions of $430-540{ }^{\circ} \mathrm{C}, 20-23$ Kbar for lawsonite-bearing eclogite (Zhang J. et al., 2007b; Zhang and Meng, 2006). Blueschists evaluated using bulk composition phase diagrams (pseudosections) yield lower peak $\mathrm{P}-\mathrm{T}$ conditions of $\sim 15 \mathrm{Kbar}$ and $450-500^{\circ} \mathrm{C}$ (Lin et al., unpublished data). Phengite from eclogite yields a ${ }^{40} \mathrm{Ar}{ }^{39} \mathrm{Ar}$ plateau age of $512 \pm 3 \mathrm{Ma}$. Paragonite from blueschist sample gives a ${ }^{40} \mathrm{Ar} /{ }^{39} \mathrm{Ar}$ plateau age of $491 \pm 3 \mathrm{Ma}$ (Zhang J. et al., 2007a).

\subsection{NQL HP/LT metamorphism}

The north Qilian (NQL) HP/LT metamorphic belt lies in the middle segment of the north Qilian Mountains and extends for about $200 \mathrm{~km}$ along the NQL suture. It occurs as WNW-trending tectonic slices within arc-type volcanic and volcanoclastic rocks that experienced greenschist-facies metamorphism (Fig. 5). These slices are mainly composed of various metabasite (blueschists and eclogite) blocks within metasediments or locally within serpentinite, representing a deep unit of an accretionary wedge or a fossil subduction channel, which is separated from lightly metamorphosed volcanic-sedimentary sequences (Zhang J. et al., 1998).

\section{Metabasites}

The term "eclogite" is used for rocks in which the modes of garnet + omphacite are more than $70 \%$, "eclogitic metabasite" for the rocks with $<70 \%$ omphacite + 
garnet, but are present as an equilibrium assemblage, and "blueschist" for metabasite with glaucophane but without omphacite.

Eclogites or eclogitic metabasites occur as pods or blocks $(0.1-50 \mathrm{~m}$ in size ) within blueschists and metasediments (Fig. 6). Some eclogites are also intercalated with blueschist layers on a centimeter to decimeter scale (Fig. $6 \mathrm{~b}$ and c). The main constituent minerals of the eclogites and eclogitic metabasites are garnet, omphacite, quartz, epidote/clinozoisite, amphibole (glaucophane and actinolite) and white mica (mainly phengite but also locally paragonite), with small amounts of rutile, titanite, chlorite, albite, and opaque minerals (Fig. 7a and b). The idioblastic garnet typically contains inclusions of omphacite, epidote/clinozoisite, glaucophane, quartz and rutile. Minor lawsonite and abundant lawsonite pseudomorphs characterized by rectangular epidote/clinozoisite-paragonite intergrowths occur as inclusions within garnet of eclogites and eclogitic metabasites, and coexist with omphacite, glaucophane and quartz (Zhang and Meng, 2006; Zhang J. et al., 2007b). Peak-pressure conditions estimated from lawsonite-omphacite-phengite-garnet assemblages were 21-24 Kbar at temperatures of $420-510{ }^{\circ} \mathrm{C}$, in or near the stability field of lawsonite eclogite (Zhang J., 2007b). In eclogites, the omphacite is fine-grained, subidioblastic, and together with phengite, glaucophane and clinozoisite constitutes the bulk of the rock matrix. These minerals define the eclogite facies foliation and lineation (Fig. 7a). Omphacite grains show undulose extinction and the formation of subgrains, indicating dynamic recrystallization related to deformation during eclogite-facies conditions. In retrogressed domains, omphacite is surrounded by secondary glaucophane, actinolite, epidote, phengite and paragonite, defining the blueschist-facies foliation and lineation. In strongly retrogressed domains, large actinolite and epidote porphyroblasts are oblique to the foliation. Garnet is partly replaced by chlorite, and the secondary glaucophane is partially replaced by Act $+\mathrm{Ab}$. Chlorite and albite also occur in the fractures of garnets. Blueschists consist mainly of garnet and glaucophane with varying amounts of epidote, phengite, actinolite, chlorite, quartz and albite (Fig. 7c). Some blueschists are intercalated with eclogites, suggesting they experienced a common peak eclogite facies metamorphism, whereas some blueschists within 
metasediments possibly experienced only a peak blueschist facies metamorphism before exhumation.

\section{Metasedimentary rocks}

HP metasedimentary rocks consist mainly of mica schist and metachert, with minor calc-schist and marble. All mica schists contain garnet and varying amounts of chloritoid, glaucophane and omphacite. Omp-bearing mica schists consist predominantly of garnet, glaucophane, omphacite, phengite and quartz with minor paragonite, rutile, epidote/clinozoisite and chlorite (Fig. 7d). Compared with eclogites and eclogitic metabasites, Omp-bearing mica schists are rich in quartz and phengite which define the schistosity. Rectangular epidote/clinozoisite, paragonite and quartz intergrowths, suggesting the former presence of lawsonite, were also observed in garnet of Omp-bearing mica schists (Zhang et al., 2007b). The oriented omphacite and glaucophane have straight grain boundaries, indicating textural equilibrium (Fig. 7d). Evidence of retrogression is indicated by the occurrence of chlorite, actinolite and albite in the fractures of garnet and omphacite. Using Grt-Cpx-Phe geobarometry and Grt-Cpx geothermometry, coexisting garnet, omphacite and phengite in Omp-bearing mica schists gave equilibrium conditions of 450-570 ${ }^{\circ} \mathrm{C}$ and $19-24 \mathrm{Kbar}$, consistent with those in eclogites (Zhang J. et al., 2012).

Glaucophane-bearing mica schists contain a mineral assemblage similar to Omp-bearing samples but omphacite is absent. Chloritoid-bearing mica schists contain a mineral assemblage of $\mathrm{Grt}+\mathrm{Cld}+\mathrm{Phn}+\mathrm{Ep}+\mathrm{Qtz} \pm$ Gln with minor rutile and carbonate minerals. Chloritoid and garnet occur as porphyroblastic crystals and are replaced partly by chlorite (Fig. 7e). Phase equilibrium calculations of Wei and Song (2008) determined peak P-T conditions from $21 \mathrm{Kbar}$ at $540{ }^{\circ} \mathrm{C}$ to $24 \mathrm{Kbar}$ at $580{ }^{\circ} \mathrm{C}$ for chloritoid-bearing mica schists.

Metacherts commonly occur as interlayers within the other metasediments and rarely as interlayers within eclogites. They have mineral assemblages of quartz + garnet + white mica (phengite + paragonite) \pm glaucophane \pm rutile. Garnet grains are euhedral and most of them have very small grain sizes $(<0.15 \mathrm{~mm})$. Some metacherts 
322 contain spessartine-rich garnet and piedmontite (Fig. 7f), suggesting that they are probably derived from manganese-rich siliceous strata which were deposited on the ocean floor.

Available ${ }^{40} \mathrm{Ar} /{ }^{39} \mathrm{Ar}$ data on phengites and glaucophanes from blueschists and mica schists yield ages of 440-460 Ma, interpreted to represent blueschist-facies metamorphism, or cooling time (Liou et al., 1989; Wu et al., 1993; Zhang J. et al., 1997, Liu et al., 2006). SHRIMP U-Pb dating of zircons from eclogites gave ages of 463-489 Ma, which were regarded as the ages of eclogite-facies metamorphism (Song et al., 2004, 2006; Zhang J. et al., 2007b).

\subsection{Comparison between the NAT and NQL HP/LT metamorphic belt}

The above data show that the both NAT and NQL HP/LT metamorphic belt contains similar rock associations, experienced similar peak metamorphic conditions and $\mathrm{P}-\mathrm{T}$ history, and are associated with ophiolitic mélange. In consideration of large scale displacement along the Altyn Tagh fault, the NAT HP/LT metamorphic belt has been considered as the western extension of the NQL HP/LT metamorphic belt. However, the present geochronological data suggest that the NAT HP/LT metamorphic belt may have formed earlier than the NQT HP/LT metamorphic belt, implying a diachronous HP/LT metamorphism along the North Altun-North Qilian suture zone. A similar case of diachronous HP metamorphism along the suture zone occurred in the Tongbai-Hong'an orogen, central China (Liu et al., 2013).

\section{4. (U)HP/MT metamorphism related to continental subduction}

UHP metamorphism, defined by the P-T conditions of the coesite stability field ( $\mathrm{P}>27 \mathrm{Kbar}$, depths $>80 \mathrm{~km}$ ), is commonly considered as a product of continental subduction and collision (e.g. Coleman and Wang, 1995), although a few UHP 
347 examples related to the oceanic subduction have been reported (Reinecke, 1991;

348 Zhang L et al., 2002; Lv et al., 2008). Eclogite and garnet peridotite were first 349 reported in the South Altun and North Qaidam in the 1990's (Liu et al., 1996; Yang et al., 1994, 1998), and later work led to the discovery of UHP evidence in eclogite, pelitic gneiss and garnet peridotite (e.g., Yang et al., 2001, 2002; Song et al., 2003 2004, 2005, Zhang J et al., 2002, 2009b, 2010; Zhang G., 2009b; Liu et al., 2002; 2012). Recently, eclogites enclosed within continental gneisses were also discovered in the east Kunlun Mountains, to the south of the Qaidam basin, although UHP

\subsection{SAT-NQD UHP/MT metamorphism}

\subsubsection{Geology of the UHPM terranes along the SAT-NQD}

In all UHP metamorphic exposures of the SAT-NQD, the eclogite and peridotite occur as blocks, boudins, or layers in the host para- and orthogneisses, and typically are tens to $1 \mathrm{~m}$ across, but locally are up to hundreds of meters across. Similar to the Dabie-Sulu UHP belt and the Western Gneiss Region of the Caledonian orogenic belt in Norway, which were considered as typical UHP terranes related to deep continental subduction, eclogites are dominantly UHP/MT eclogites (Mattinson et al., 2007; Song et al., 2014 and references therein).

The SAT-NQD UHP metamorphic belt is mainly composed of orthogneisses and paragneisses, similar to most continental type UHP terranes worldwide. Although 
374 most orthogneisses and paragneisses enclose UHP eclogite blocks, HP and UHP assemblages are less preserved in these gneisses, which might be partially explained by the more extensive retrograde recrystallization, typical of felsic rocks (e.g., Proyer, 2003). The magmatic protolith ages of most orthogneisses in the SAT-NQD are Late Mesoproterozoic-Early Neoproterozoic (890-1030 Ma ) (Wan et al., 2001, 2006; Zhang J. et al., 2008; Zhang C., 2012; Gehrels et al., 2003a; Mattinson et al., 2006a; Wang C. et al., 2007, 2013; Yu et al., 2013; Song et al., 2012). Some paragneisses record an almost concurrent metamorphism at 895-945 Ma (Zhang J. et al., 2008; Zhang C., 2012; Yu et al., 2013). The Late Mesoproterozoic-Early Neoproterozoic tectonothermal event in SAT-NQD has been interpreted as a Grenvillian orogeny that assembled the supercontinent Rodinia (Wan et al., 2006; Zhang J. et al., 2008; Song et al., 2012; Yu et al., 2013; Wang et al., 2013). This is also similar in age to the Jinning (or Sibao) orogeny commonly recognized in the South China block (Yangtze block), which is absent from the North China block. A few orthogneisses in Dulan area, eastern NQD, have Mesoproterozoic to Paleoproterozoic protolith ages (Song et al., 2013; Yu and Zhang, 2011; Mattinson et al., unpubl.). Similar Mesoproterozoic-Paleoproterozoic gneisses are commonly recognized in the Quanji massif (Olongbuluke microcontinent) to the north of Dulan UHP terrane. This suggests that parts of the Quanji massif may have been subducted, either on the downgoing plate, or by tectonic erosion of the upper plate (Yin et al., 2007).

Most SAT-NQD eclogites have protolith ages ranging from $750 \mathrm{Ma}$ to $850 \mathrm{Ma}$ (Zhang J. et al., 2005b, 2010; Song et al., 2010; Liu et al., 2012). A similar protolith age was obtained in SAT garnet peridotite and garnet pyroxenite (Wang et al., 2011; Li et al., 2015). Combining the ages with geochemical data suggests that the protoliths of these eclogites and garnet peridotites formed during the continental rifting that broke up Rodinia (Zhang J. et al., 2005b, 2010, 2011; Song et al., 2010; Wang et al., 2011, 2013; Li et al., 2015). Together with the major component of Grenville-age gneisses, this suggests that the subducted continental slab may represent part of the Rodinia Supercontinent. In addition to these continental-derived protoliths, oceanic-derived protoliths are also present. An eclogite from the Shaliuhe section of 
404 the Dulan UHP terrane yielded a protolith age of 516 Ma (Zhang G., et al., 2008), and geochemical data suggest that the protolith of this eclogite was derived from gabbroic cumulates, representing part of an ophiolite sequence (Zhang G. et al., 2008). This sample is interpreted to record oceanic subduction that preceded continental subduction and collision (Song et al., 2006, 2014; Zhang G., et al., 2013).

\subsubsection{Petrology and P-T evolution of the UHP terranes along the SAT-NQD}

Petrologic and thermobarometric evidence for UHP metamorphism is recognized in several UHP exposures in the SAT-NQD. Petrologic evidence includes the presence of coesite in garnet and zircon from eclogite and paragneiss at Dulan, Xiteishan and Yuka of the NQD, diamond in zircon from garnet peridotite at Luliangshan of the NQD, and coesite pseudomorphs in garnet from eclogite at Jianggalesayi of the SAT (Yang et al., 2001, 2002; Song et al., 2003, 2005; Zhang J., 2002, 2009b, 2010; Zhang G., 2009a, b; Liu et al., 2012). The P-T estimates give similar MT (670-800 $\left.{ }^{\circ} \mathrm{C}\right)$ and UHP (27-33 Kbar) peak metamorphic conditions for eclogites from the various UHP units (Zhang J., et al., 2001, 2010; Song et al., 2003, 2006; Chen et al., 2009; Zhang C. et al., 2009, 2011; Zhang G. et al., 2009a). Thermobarometry of garnet peridotite at Luliangshan of the NQD yields a higher peak $\mathrm{P}-\mathrm{T}$ condition up to $46-65 \mathrm{Kbar}$ and $980-1130{ }^{\circ} \mathrm{C}$ (Song et al., 2004, 2005). However, the retrograde $\mathrm{P}-\mathrm{T}$ paths are disparate for different UHP units. UHP rocks at Yuka and north Dulan record near-adiabatic decompression to amphibolite-facies conditions (Zhang J., et al., 2005b; Chen et al., 2009; Zhang G., 2009a; Fig. 8). In contrast, eclogites at Xitieshan, Luliangshan and Jianggelesayi record high-temperature (HT) granulite-facies conditions during decompression (Zhang J., 2005b; Zhang C., 2011; Fig. 8), corresponding to the Barrovian metamorphic overprinting (see below).

\subsubsection{Metamorphic ages for UHP terranes along the SAT-NQD}

A large number of zircon $\mathrm{U}-\mathrm{Pb}$ ages have been reported for UHP metamorphic rocks of the SAT-NQD. For the SAT, all geochronological data show that the age of 
431 the UHP metamorphism recorded in eclogite and garnet peridotite is 500-482 Ma.

432 However, timing of UHP metamorphism for some NQD UHP rocks remains controversial. The previous TIMS U-Pb data of Yuka eclogites, western NQD, gave ages ranging between $486-495 \mathrm{Ma}$, and ${ }^{40} \mathrm{Ar} /{ }^{39} \mathrm{Ar}$ dating gave ages of $466-477 \mathrm{Ma}$ (Zhang J., 2005b). The TIMS age was recently explained as a possible mixing age of metamorphic domains and residual cores, and ${ }^{40} \mathrm{Ar} /{ }^{39} \mathrm{Ar}$ dating data have a possibility of excess Ar (Liu et al., 2009; 2012). Recently, rutile U-Pb dating of eclogites in western NQD gave an age at ca. 410Ma, interpreted as the cooling age (down to $530{ }^{\circ} \mathrm{C}$ (Zhang G., 2014). Most zircon SHRIMP and LA-ICPMS U-Pb dating data yielded ages ranging from 420 to 460 Ma. Combining ages with petrological and geochemical data, Song et al. (2006, 2014) suggested an earlier oceanic subduction (440-460 Ma), followed by continental subduction (420-440 Ma). Although an earlier oceanic subduction can not be excluded, most of the published data show eclogite and host gneiss have a similar age range, suggesting an in situ relationship. We therefore prefer to explain that the NQD UHP metamorphism may be diachronous or protracted during continental subduction and collision (Mattinson et al., 2006b, 2007; Zhang J. et al., 2008, 2010).

A relevant question that arises from the above description is how to explain the different UHP metamorphic age between the SAT and NQD. Based on the difference of UHP metamorphic ages, some authors suggest that the SAT and NQD possibly originated from different tectonic belts, and do not correlate across the Altyn Tagh fault (e.g. Liu et al., 2012). However, within the same orogenic belt, different (U)HP exposures may have significant age variation. For example, in the Alps, the age of (U)HP metamorphism in different (U)HP nappes varies over more than $55 \mathrm{Ma}$, from the Cretaceous (ca. $91 \mathrm{Ma}$ ) in the Pohorje Mountains of the Eastern Alps (Miller et al., 2005 ) to ca. $65 \mathrm{Ma}$ in the Sesia-Lanzo zone (Rubatto et al., 1999), to ca. $35 \mathrm{Ma}$ in the Dora Maria massif (Gebauer et al., 1997). Another well-confirmed example comes from the Tongbai-Hong'an-Dabie-Sulu HP/UHP metamorphic belt. The ages of different HP/UHP slices from this belt are also different, lasting from ca. $255 \mathrm{Ma}$ to ca. $220 \mathrm{Ma}$ (Liu et al., 2004, 2007, 2009, 2010). 
Eclogites recently discovered in the eastern part of the East Kunlun Mountains (Meng et al., 2013) occur as lenses within paragneiss of the Jinshuikou Group, which was previously considered to represent the Precambrian metamorphic basement of the north Kunlun-Qaidam block (Wang and Chen, 1987; Wang et al., 2004, 2007; Chen et al., 2006). These eclogite lenses are about $20 \mathrm{~m}$ long and 5-10 m wide, and the rims are partially retrogressed to garnet amphibolite. Ultramafic blocks composed of serpentinized peridotite and tremolitized pyroxenite are also distributed within paragneisses as lenses. The paragneisses mainly consist of muscovite, biotite, plagioclase, K-feldspar and quartz, with minor garnet. They show a well-developed foliation defined by oriented biotite and muscovite. Eclogite consists of Grt + Omp + Qtz + Rt. Garnet compositions are $\mathrm{Alm}_{48-55} \operatorname{Prp}_{16-29} \mathrm{Grs}_{19-29} \mathrm{Sps}_{1-2}$, and omphacite has a varying jadeite content of $21-63 \%$. The peak metamorphic assemblage of eclogites records a $\mathrm{P}-\mathrm{T}$ condition of $>16 \mathrm{Kbar}$ and $590-650{ }^{\circ} \mathrm{C}$. Zircon $\mathrm{U}-\mathrm{Pb}$ dating of the inherited magmatic zircons from eclogites reveals a Neoproterozoic age of $934 \mathrm{Ma}$, representing the protolith age of the eclogite. Zircons with inclusions of garnet, omphacite and rutile yield a weighted mean age of $428 \pm 2 \mathrm{Ma}$, which is interpreted as the metamorphic age of the eclogite.

Recently, retrogressed eclogite was also recognized at Xiarihamu, in the western part of the east Kunlun Mountains (Qi et al., 2014). Similar to the eclogites in the eastern part of the east Kunlun Mountains, these eclogites occur as lenses with the Jinshuikou Group gneisses. They show strong amphibolization with rare omphacite relicts $(\mathrm{Jd}=30-37 \mathrm{~mol} \%)$. U-Pb zircon dating gave a metamorphic age of $411 \pm 2$ Ma. Considering the strong amphibolite overprinting, it remains unclear if this age represents the timing of eclogite facies metamorphism or later amphibolite facies overprinting. 


\section{HP/(U)HT granulite facies metamorphism}

In the SAT-NQD, HP felsic and mafic granulites are recognized at Bashiwake of the SAT, and Luliangshan, Xitieshan, and Aercituoshan (Dulan area) of the NQD. To discuss the paragenetic relationship between HP mafic granulite and associated eclogite, this section emphasizes HP mafic granulite. Based on field geology, petrological and geochronolgical data, two types of HP mafic granulites have been recognized in the SAT-NQD (Zhang J., 2009c, 2014; Yu et al., 2011, 2014). One type of HP mafic granulite (i.e. Luliangshan) was formed by overprinting of eclogite during exhumation. Another type of HP mafic granulite (i.e. Bashiwake, and Aercituoshan of Dulan) experienced a single metamorphic evolution distinct from the UHP eclogites.

\subsection{Luliangshan HP mafic granulite}

The Luliangshan HP mafic granulites occur as lenses ranging in size from $<1 \mathrm{~m}$ to tens of metres long within garnet-kyanite (sillimanite)-biotite gneisses. Petrologic and mineralogical data indicate a multi-stage metamorphic history. An earlier eclogite-facies metamorphism is deduced from the clinopyroxene-plagioclase intergrowths and rare omphacite inclusions within garnet (Zhang J. et al., 2007c) (Fig. 9). The HP granulite assemblages consist of garnet, clinopyroxene, plagioclase and quartz (Fig. 9a and b), yielding P-T conditions of 9.6-13.7 Kbar and $730-870{ }^{\circ} \mathrm{C}$, similar to $\mathrm{P}-\mathrm{T}$ conditions of $11-13 \mathrm{Kbar}$ at $800^{\circ} \mathrm{C}$ for the Grt-Ky-Kf-Pl-Qtz assemblage in the host felsic granulite (Zhang J. et al., 2008). Later reactions led to growth of orthopyroxene around garnet or the symplectite domains (Fig. 9c and d), indicating a significant drop in pressure $(\mathrm{P}=6.2-8.5 \mathrm{Kbar})$ under similar temperatures $\left(\mathrm{T}=720-860{ }^{\circ} \mathrm{C}\right)$, corresponding to medium-low pressure granulite facies overprinting (see below).

SHRIMP U-Pb dating of zircons of mafic and felsic granulites reveals two age groups: ca. $450 \mathrm{Ma}$ and ca. $425 \mathrm{Ma}$. The former was interpreted to represent the age of HP granulite metamorphism based on rare inclusions of Grt + Rt, and the later 
$516+$ Sil inclusions in zircons of felsic granulite (Zhang J. et al., 2008, see below).

517 However, Grt + Rt inclusions are also consistent with eclogite facies metamorphism.

518 In this case, the HP granulite facies metamorphic overprinting should happen

519 between $450 \mathrm{Ma}$ and $425 \mathrm{Ma}$. In addition, the Luliangshan unit is intruded by granite 520 plutons of $428 \pm 10 \mathrm{Ma}$, so HP granulite metamorphism must be earlier than ca. 428 521 Ma (Zhang J., et al., 2008).

\subsection{South Dulan HP/HT granulite}


545 granulite to be younger than eclogite. (4) The latest petrologic research in the area suggests that the south Dulan eclogite directly retrogressed to amphibolite-facies during decompression without HP granulite-facies overprinting (Zhang G. et al., 2009a; Zhang J. et al, 2010). (5) In the field, no direct contact between the eclogite unit and HP granulite unit has been observed, and a fault contact between the two rocks types is inferred.

Thermobarometric data suggests that the south Dulan HP granulite experienced peak metamorphic $\mathrm{P}-\mathrm{T}$ conditions of $14-18 \mathrm{Kbar}$ and $800-950{ }^{\circ} \mathrm{C}$ (Yu et al., 2009, 2011; Christensen, 2011). Petrographic observations show that the HP granulite preserves features diagnostic of anatexis and locally may be described as migmatite consisting of pale plagioclase-rich quartzofeldspathic layers (leucosome) and dark garnet-clinopyroxene-rich melanosome domains (Fig. 10a). The leucosome is interpreted as the former sites of melt segregation and/or accumulation, and melanosome as the residuum from which melt has been extracted (Yu et al., 2012; 2014, Song et al., 2014b). The relative proportion of leucosome and melanosome varies widely. The leucosome ranges in composition from tonalite to granite and contains small amounts of garnet, clinopyroxene and kyanite in addition to feldspar and quartz, and thus is called "felsic HP granulite" although it represents melt formed by anatexis (Fig. 10d). The leucosome component shows a chemical resemblance to adakites (Yu et al., 2012; Song et al., 2014b, Zhang G., 2015), and probably resulted from partial melting of thickened mafic lower crust $(>50 \mathrm{~km})$ compatible with peak P-T estimates from mafic HP granulites (Yu et al., 2012).

Zircon $\mathrm{U}-\mathrm{Pb}$ dating yields ages of $449 \pm 3,435 \pm 3,434 \pm 3$, and $418 \pm 2 \mathrm{Ma}$ for mafic and intermediate HP granulite, and $433 \pm 5,437 \pm 3$, and $438 \pm 4$ Ma for felsic HP granulite (leucosome), which were interpreted as timing of the peak metamorphism and partial melting (Yu et al., 2014; Christensen, 2011). ${ }^{40} \mathrm{Ar} /{ }^{39} \mathrm{Ar}$ amphibole ages of $423-432 \mathrm{Ma}$ are interpreted to represent amphibolite-facies retrograde metamorphism and suggest a rapid cooling during exhumation of the HP granulites (Yu et al., 2014). These geochronologic data, combined with field relationships, petrology and geochemistry suggest that HP granulite-facies 
metamorphism and the partial melting that produced adakitic melts represent the same tectonic event. In this case, the felsic HP granulites (leucosome) formed from an adakitic melt derived from partial melting of mafic HP granulite in the overriding plate in a relatively higher geothermal gradient $\left(15-18{ }^{\circ} \mathrm{C} / \mathrm{km}\right)$, leaving garnet-cumulate and/or meta-ultramafic (mainly garnet pyroxenite) as the residual component (Zhang J. et al., 2009c; Yu et al., 2011, 2012, 2014). In contrast, the nearby UHP eclogite is thought to have formed in the subducted plate in a relatively lower geothermal gradient $\left(6-10^{\circ} \mathrm{C} / \mathrm{km}\right)$ (see discussion section).

\subsection{Bashiwake $H P /(U) H T$ granulite}

In the SAT subduction-collision complex, a HP granulite-garnet peridotite unit has been recognized in the Bashiwake area. It occurs as a tectonic block of HP felsic granulite, mafic granulite and garnet peridotite, separated from amphibolite-facies gneisses by ductile shear zones (Zhang J. et al., 2005c, 2014). Felsic granulites (leucogranulites) predominate within this unit, whereas mafic granulites and garnet peridotites are subordinate and occur as lenses within felsic granulites (Fig. 11). The peak assemblages are represented by garnet + kyanite + perthite (former ternary feldspar) + quartz in felsic granulite, and garnet + clinopyroxene \pm perthite \pm kyanite + plagioclase + quartz in mafic granulite (Zhang J. et al., 2005c) (Fig. 11). Major mineral thermobarometry suggests that $\mathrm{HP}$ granulite experienced peak $\mathrm{P}-\mathrm{T}$ conditions of $870-1050{ }^{\circ} \mathrm{C}$ and $19-25 \mathrm{Kbar}$, followed by a medium-high pressure granulite facies overprint $\left(780-820{ }^{\circ} \mathrm{C}, 9.5-12 \mathrm{Kbar}\right)$, which is defined by the formation of secondary clinopyroxene \pm orthopyroxene + plagioclase at the expense of garnet + early Al-rich clinopyroxene in the mafic granulites, as well as by growth of spinel, sapphrine and plagioclase at the expense of garnet and kyanite in the felsic and mafic granulite (Fig. 11e and f). These data show ultrahigh temperature (UHT) conditions at high pressure. These unusual $\mathrm{P}-\mathrm{T}$ conditions are higher than those of the vast majority of granulites in the world, but are similar to those of (U)HP/UHT granulites in the Bohemian Massif of the European Variscan orogen (Carswell and 
603 O’Brien, 1993; Rötzler and Romer, 2001; O’Brien and Rötzler, 2003; Kotkova, 2007;

604 O'Brien, 2008, and references therein). Field relations and petrographic observations 605 show that the formation and/or post-peak evolution of the Bashiwake granulite 606 involved some degree of melting (Zhang J. et al., 2005c, 2014), but the extent of 607 608 609

\section{Regional Barrovian type metamorphism} melting and its relation to the granulite $\mathrm{P}-\mathrm{T}$ path are still unclear.

Zircon U-Pb geochronology yielded ages of $493 \pm 7 \mathrm{Ma}$ and $495 \pm 4 \mathrm{Ma}$ for the felsic granulite (Zhang J. et al., 2005c, 2014), $497 \pm 11$ Ma for mafic granulite (Zhang J. et al., 2005c), interpreted as dating the HP/HT (UHT) granulite facies metamorphism (Zhang J. et al., 2005c). Similar metamorphic ages were also obtained by zircon $\mathrm{U}-\mathrm{Pb}$ dating of garnet peridotite (Zhang J. et al., 2005c; Wang et al., 2011, Li et al., 2015). Rutile $\mathrm{U}-\mathrm{Pb}$ dating of felsic and mafic granulites obtained an age of ca. $450 \mathrm{Ma}$ which is interpreted as timing of the post-peak reheating under MP/MT granulite-facies conditions, in combination with Zr-in-rutile thermometry (Zhang J. et al., 2014).

Before UHP metamorphism was recognized in collisional orogeny, Barrovian type (MP) metamorphism was considered to be a characteristic of collisional orogenesis (e.g. Dewey and Bird, 1970; England and Thompson, 1984; Wiederkehr et al., 2008; Berger et al., 2011; Jolivet et al., 2003). Since the discovery of coesite in eclogites and associated rocks from Alps (Chopin, 1984) and Norwegian Caledonides (Smith, 1984), UHP metamorphic rocks have been reported from a number of collisional orogenic belts over the world (Liou et al., 2004, Maruyama et al., 2010 and references therein). However, UHP metamorphic rocks occupy a volumetrically minor part of the whole collision orogen. The predominant metamorphic rocks are still Barrovian type metamorphic rocks. Some authors suggest that the rare preservation of UHP-HP metamorphic rocks is due to the overprint of the widespread Barrovian type 
metamorphism (e.g. Liou et al., 2004; Winter, 2001). Recently, Aoki et al. (2014) suggest that that the classic Barrovian metamorphism of Scotland may also have overprinted a higher pressure pre-history. However, the presence of Barrovian type metamorphism is still typical of many collisional orogens, although Barrovian type metamorphism has received insufficient attention in the past twenty years, compared with UHP metamorphism. A common feature of collisional orogens is coeval anatexis (partial melting) and granitic magmatism related to Barrovian type metamorphism (e.g. Keay et al., 2001; Whitney et al., 2003 and references therein). As for the SAT-NQD, similar to most collisional orogens worldwide, the predominant metamorphic rocks of the SAT-NQD are low-medium pressure metamorphic rocks, in which rare or no early HP-UHP evidences were preserved.

\subsection{SAT Barrovian type metamorphism and anatexis}

In the SAT, UHP eclogites, HP granulite and garnet peridotite are only recognized in a few localities (Fig. 1). The predominant high-grade metamorphic rocks, called the "Altun Group", mainly consist of amphibolite- to granulite-facies granitic gneiss, pelitic gneiss, migmatite, marble, quartzite, amphibolite, and mafic granulite. Here we report a typical Barrovian type metamorphic association in the Tula area of the SAT (Fig. 12). Based on new petrologic and chronologic data in combination with previous work, we will constrain the relationship between Barrovian type metamorphism, partial melting and granite intrusion in the SAT.

In the Tula area of the SAT (Fig. 12), granulite-facies associations include migmatitic metapelites and graphite-bearing marbles that host minor mafic granulite lenses and layers within them (Zhang J. et al., 2000). These rocks form a unit extending for about $20 \mathrm{~km} \mathrm{E-W.} \mathrm{They} \mathrm{are} \mathrm{truncated} \mathrm{by} \mathrm{the} \mathrm{ENE-WSW} \mathrm{Altyn} \mathrm{Tagh}$ main fault on the south, but the boundary to the northern eclogite-bearing unit remains unclear (Fig. 12).

Migmatitic metapelites consist of garnet, sillimanite, biotite, feldspar and quartz with minor graphite and accessory zircon and monazite. The aligned sillimanite and 
657 biotite define a foliation (Fig. 13a and b). Quartzofeldspathic leucosomes parallel to 658 the foliation occur as thin layers (several $\mathrm{mm}$ to $\mathrm{cm}$ wide) in the metapelite (Fig. 13a). 659 Minor garnet grains observed in the leucosomes are interpreted to be peritectic. Under 660 the microscope, highly cuspate, arcuate K-feldspar grains envelop the quartz grains or 661 elongated, veinlet-like K-feldspar intrude into garnet, or a K-feldspar + quartz + 662 plagioclase assemblage is included in garnet, which could be interpreted as pseudomorphs of former melts (Fig. 13c and d). These features suggest in situ partial melting of metapelites. Mafic granulite mainly consists of orthopyroxene (hypersthene), clinopyroxene, brown amphibole, biotite and plagioclase with or without garnet (Fig. 13e-h). Previous geothermobarometry gave a peak P-T condition of 8-12 Kbar and $700-850^{\circ} \mathrm{C}$ for the mafic granulites and metapelite (Zhang J. et al., 2000; Table 1). Our new data give a slightly lower pressure of 6.5-8.0 Kbar and similar temperature $780-820^{\circ} \mathrm{C}$ using the GASP barometer (Grt-Sil-Pl-Qtz) and Grt-Bt thermometer for metapelites, and the GADS barometer and Grt-Cpx thermometer for mafic granulites (Table 1).

The previous zircon $\mathrm{U}-\mathrm{Pb}$ dating yielded ages of $450 \pm 4 \mathrm{Ma}$ (TIMS) for mafic granulite and $448 \pm 7 \mathrm{Ma}$ (SHRIMP) for migmatitic metapelite (Table 1; Zhang J. et al., 2000, 2011). Our new zircon U-Pb analyses by SHRIMP and LA-ICPMS gave ages of $436 \pm 4 \mathrm{Ma}$ for mafic granulite and $457 \pm 2 \mathrm{Ma}$ for migmatitic metapelite (Fig. 14). These ages are interpreted as the timing of granulite-facies metamorphism and associated anatexis in the Tula area of the SAT.

Similar ages have been commonly reported in various rocks of the other areas of the SAT. For example, at Jianggelesayi, a main locality in which eclogites are exposed, Grt-Bt \pm Sil \pm Ky gneiss hosting eclogite lenses gave ages of $450 \pm 3$ and $450 \pm 5 \mathrm{Ma}$, whereas eclogites have a peak metamorphic age at ca. 482-500 Ma and a granulite facies overprinting age at ca. $450 \mathrm{Ma}$ (Zhang J. et al., 2001a, unpublished data; Liu et al., 2012; Mattinson et al., unpublished data); in the Bashiwake area, the ca. $450 \mathrm{Ma}$ age is recognized in both mafic granulite and felsic granulite, and is interpreted to reflect the timing of MP granulite-facies metamorphic overprinting (or reheating), after an earlier HP granulite-facies (or eclogite facies) metamorphism (Zhang J. et al., 
687 2005c; 2014). These data also imply that a common MP (Barrovian) granulite-facies

688

689

690

691

692

693

694

695

696

697

698

699

700

701

702

703 metamorphic event happened throughout the SAT at $450 \mathrm{Ma}$, which postdates an earlier (U)HP eclogite facies metamorphism by about 30-50 Ma. However, it remains unclear if all SAT Barrovian type granulite facies metamorphic rocks have an earlier (U)HP history.

Moreover, similar to the timing of MP granulites, 440-460 Ma granite intrusions also were recently recognized in different localities in the SAT (Zhang J. et al., 2014). Geochemical data suggest that all these granites have characteristics of high-K calc-alkaline S-type granite and might be derived from partial melting of pelitic-arenaceous sedimentary rocks in a lower crustal environment (ca. $800{ }^{\circ} \mathrm{C}$ and $10 \mathrm{Kbar}$ ) (Cao et al., 2010; Yang et al., 2012; Kang et al., 2013, 2015).

\subsection{NQD Barrovian type metamorphism and anatexis}

Similar to the SAT, the predominant high grade metamorphic rocks are felsic gneiss (schist) in the NQD. Although rare (U)HP evidence (i.e. coesite inclusions in Dulan paragneiss; relict (U)HP mineral assemblages in Yuka metapelite) are recognized in some gneisses (Yang et al., 2002; Song et al., 2003; Zhang J. et al., 2004), the outstanding characteristics of these gneisses are the preservation of the low to medium-P amphibolite- to granulite-facies assemblages. Based on published petrologic and chronologic data, in this section we examine the relationship between Barrovian metamorphism, anatexis and granite intrusion in the Luliangshan and Xitieshan areas.

In both Xitieshan and Luliangshan units, the paragneisses mainly consist of garnet, kyanite, sillimanite, K-feldspar, plagioclase, quartz, and biotite with accessory rutile, zircon and monazite (Fig. 15). The mineral assemblage $\mathrm{Grt}+\mathrm{Sil}+\mathrm{Bt}+\mathrm{Pl}+\mathrm{Qtz}$ and GASP equilibria $(\mathrm{Grs}+2 \mathrm{Sil}+\mathrm{Qtz}=3 \mathrm{An})$ give temperatures of $740-830{ }^{\circ} \mathrm{C}$ and pressures of 6-8 Kbar (Zhang J. et al., 2008), reflecting low-medium pressure granulite-facies conditions. A HP granulite-facies assemblage of $\mathrm{Grt}+\mathrm{Ky}+\mathrm{Pl}+\mathrm{Kfs}$ 
$715+$ Qtz + Rt is locally preserved, and yields pressures of $11-13 \mathrm{Kbar}$ at $800{ }^{\circ} \mathrm{C}$ (see 716 above, Zhang J. et al., 2008; 2009a). Mafic granulite lenses ( $<1 \mathrm{~m}$ to tens of meters 717 long) within paragneisses are also recognized in the Luliangshan unit. They are mainly composed of garnet, clinopyroxene, orthopyroxene, plagioclase, amphibole, and quartz with minor rutile, ilmenite and zircon. Petrographic data and P-T calculations suggest a low-medium pressure, granulite-facies stage at $6.2-8.5 \mathrm{Kbar}$ and $730-850{ }^{\circ} \mathrm{C}$ after a HP granulite-facies stage $\left(10-14 \mathrm{Kbar}\right.$ and $\left.720-830{ }^{\circ} \mathrm{C}\right)$ and a possible eclogite-facies stage (see above).

Field and microscopic observation support a common migmatization and anatexis for gneisses. Quartzofeldspathic leucosomes occur as thin layers in the gneisses. The proportion of thin leucosomes varies greatly from outcrop to outcrop and the leucosomes range in thickness from millimeters to decimeters ( $\mathrm{Yu}$ et al., 2015). The leucosomes are generally aligned subparallel to the foliation defined by oriented biotite and sillimanite. Microscopic evidence includes: (1) highly cuspate, elongated feldspar grains along quartz-quartz and quartz-feldspar boundaries, (2) cuspate wedge-shaped pockets of K-feldspar + quartz + plagioclase \pm muscovite along the boundaries of quartz and/or plagioclase, and (3) felsic veinlets of K-feldspar + quartz \pm plagioclase \pm muscovite along grain boundaries (Yu et al., 2015).

$\mathrm{U}-\mathrm{Pb}$ dating of zircons, combining with trace element analyses and mineral inclusions in zircon, reveals two Early Paleozoic age groups for migmatitic paragneisses: ca. 444-460 Ma represents the age of (U)HP metamorphism, whereas ca. 425-433 Ma reflects the time of low-medium pressure granulite-facies metamorphic overprint and associated anatexis (Zhang J. et al., 2008; Yu et al., 2014, 2015).

Granitic magmatism (ca. $428 \mathrm{Ma}$ ) is synchronous with low-medium $\mathrm{P}$ granulite facies metamorphism in the Luliangshan and Xitieshan areas (Meng et al., 2005; Meng and Zhang, 2008; Zhang J. et al., 2008). The Luliangshan granitic pluton occupies an area of $\sim 60 \mathrm{~km}^{2}$. Field observation shows an intrusive contact relation with the surrounding gneiss. Geochemical data suggest that the Luliangshan granite has characteristics of calc-alkaline and peraluminous rocks with high initial ${ }^{87} \mathrm{Sr} /{ }^{86} \mathrm{Sr}$ ratios of 0.7108 and $\varepsilon \mathrm{Nd}_{\mathrm{t}}$ values of -5.5 to -4.6 , and was inferred to be derived from 
745 melting of metasedimentary rocks similar to country paragneisses (Meng and Zhang, 746 2008). SHRIMP U-Pb dating of zircons from the Luliangshan granite gave an age of $747428 \pm 8 \mathrm{Ma}$. The Xitieshan granite pluton is a long, SSE trending, $\sim 15 \mathrm{~km}^{2}$ intrusion. 748 Geochemical data suggest that the Xitieshan granite has major and trace element compositions similar to surrounding felsic gneiss, implying that it originated from a deeper partially molten source with a composition similar to the felsic gneiss of the Xitieshan unit. TIMS U-Pb dating of zircons gave an age of $428 \pm 1 \mathrm{Ma}$ (Meng et al., 2005), nearly coeval with low-medium pressure granulite-facies metamorphism of the host gneisses.

The data above show that regional-scale Barrovian metamorphism in the SAT-NQD has a close spatial and temporal relationship to granitoid emplacement. Coeval metamorphism and magmatism represent responses to an increased geothermal gradient caused by conductive heating during crustal thickening related to collision, or by thermal relaxation after (U)HP metamorphism related to continental subduction. The low-medium pressure Barrovian metamorphism is about 25-50 Ma later than the (U)HP metamorphism.

\section{Discussion: Linking metamorphism to orogenesis}

Orogenesis is a complex concept that refers not only to mountain building but also to the formation of continental crust and major orogenic structures (e.g. Ota and Kaneko, 2010). Regional metamorphic rocks, which occupy the orogenic core and hence are the most important element of an orogen, record information that may be used to determine the tectonothermal evolution of the crust with time in orogenic systems (e.g. Brown, 2006). Observation in modern active convergent plate margins and comparison with ancient analogues suggests two types of orogenic systems, i.e. oceanic subduction-related accretionary-type and continent-continent collision-type. The former, also called "Pacific-type" (Matsuda and Uyeda, 1971) or "Cordilleran 
type" (Coney et al., 1980), is characterized by the formation of subduction-accretion complexes with a HP/LT metamorphic belt involving blueschists and eclogites, and extensive calc-alkaline magmatism that contributes significantly to the volume of continental crust. It forms by ongoing plate convergence in the absence of continental collision. Typical examples include the Paleozoic Central Asia Orogen, and the Mesozoic-Cenozoic Circum-Pacific Orogen (Coney, 1992; Sengör and Natal'in, 1996). In contrast, orogenesis in a collision-type orogenic system is characterized by the formation of a regional HP-UHP metamorphic belt related to continental subduction, but contributes very little to continental growth, because it involves no more than the reworking of pre-existing continental material. Typical examples are the Cenozoic Alpine-Himalayan orogen, and Mesozoic Dabie-Sulu orogen in eastern China. These two orogenic types, however, do not represent two end members of one spectrum, as the former is destined to change into the latter with time.

Distinct orogenic processes and mechanisms determine the differences of metamorphic pattern between the two types of orogenic systems. In an accretionary orogenic system, juvenile materials are produced mainly by the formation of an accretionary wedge and calc-alkaline magmatic arc, which are related to the subduction of oceanic lithosphere. It is oceanic subduction that results in the formation of HP/LT metamorphic belts consisting mainly of blueschist and LT eclogite. Contemporaneously, devolatilization of subducted, hydrated oceanic crust promotes the generation of calc-alkaline arc melts and LP/HT metamorphism in island arc zone, forming classic paired metamorphic belts, which are the hallmark of accretionary orogeny (Miyashiro, 1961; Ernst, 2005, 2010; Brown, 2007, 2008, 2009, 2010). In a collisional orogenic system, the consumption of ocean lithosphere causes subduction of a continental plate beneath another continental plate to mantle depth, resulting in the UHP metamorphism of continental crust. Underthrusting and collision between two continent blocks can also lead to crustal thickening and shortening, and HP granulites may form in the thickened orogenic lower crust (e.g. eastern Himalaya, Liu and Zhong, 1997). Moreover, in collisional orogenic systems, another important characteristic is widespread Barrovian type regional metamorphism, which may mask 
an earlier (U)HP metamorphic history (e.g. in Himalayan and Caledonian orogens, see Liou et al., 2004; Walsh and Hacker, 2004 and references therein). In collisional orogenic systems, different types of metamorphism (e.g. UHP metamorphism \& HP granulite metamorphism) may occur contemporaneously in different thermal environments (Konopasek and Schuilmann, 2005; Zhang J. et al., 2009c, 2014), suggesting another type of "paired metamorphic belt", i.e. UHP eclogite facies belt vs. HP granulite facies belt, which may be characteristic for collisional orogeny (Zhang J. et al., 2009c, see below). Brown (2009) also extends the concept of "paired metamorphic belts" more widely than accretionary orogens, outside the original usage of Mihashiyo (1961), to collisional orogens and incorporates all types of dual metamorphic belts.

The present data suggest a polymetamorphism for the Altun-Qilian-Kunlun (AQK) orogenic system of northern Tibet during the early Paleozoic (Fig. 16; Table 2). The polymetamorphism can be linked to early Paleozoic orogenesis. The NAT -NQL HP/LT metamorphism is related to accretionary orogenesis during early Paleozoic oceanic subduction. In particular, the lawsonite eclogite and carpholite-bearing metapelite suggest that subducted oceanic crust has transported abundant water into mantle (Zhang and Meng, 2006; Zhang J. et al., 2007b; Song et al., 2007; Wei and Song, 2008). The devolatilization of these sinking, hydrated oceanic materials promotes the generation of calc-alkaline arc melts in the NAT -NQL (Zhang J. et al., 1997; Xia et al., 2003; Wu et al., 2005), and produced an early-Paleozoic trench-arc-basin system (e.g. Xu et al., 1994; Xia et al., 2003), reflecting a northward subduction direction (convergence) of the Paleo-Qilian ocean (Prototethys). Moreover, along the northern margin of the Qilian block (southern margin of NQL), several Alaska-type, zoned mafic complexes and arc granites with an age of ca. 500 Ma have been recognized (Zhang Q. et al., 1997, Wu et al., 2009, Zhang J. et al., unpublished data), nearly coeval with the oldest eclogite age (489 Ma) in the NQL. The igneous rocks have geological and geochemical features that indicate an origin related to the southward subduction of the north Qilian ocean (Gehrels et al., 2003a, b; Xiao et al., 2009; Zhang J. et al., 2012). Our new data suggest the 
831 occurrence of ca. $500 \mathrm{Ma}$ LP/HT metamorphic rocks (Grt-Sil-Crd gneiss) associated 832 with arc magmatism in the northern margin of the Qilian block (at Qingshizhui and 833 Kekeli, Zhang J. et al., unpublished data), also reflecting southward subduction and a 834 possible paired metamorphic belt together with NQL HP/LT metamorphic rocks.

835 The SAT-NQD is characterized by the occurrence of UHP eclogites, garnet 836 peridotites and predominant felsic gneisses. Although some eclogites may be related 837 to the subduction of oceanic crust during the early Paleozoic (e.g. Song et al., 2006; 838 Zhang G. et al., 2008), petrological and geochronological data suggest that the 839 protolith of most eclogites was derived from middle Neoproterozoic (750-850 Ma) 840 mafic igneous rocks in a continental rifting setting, and most host gneiss protoliths 841 were derived from early Neoproterozoic granite and Neo-Meso-Proterozoic 842 sedimentary rocks (Zhang J. et al., 2005a, 2006, 2010; Liu et al., 2009, Song et al., 843 2010; Yu et al., 2013). All these continental rocks were subducted to mantle depth 844 during the early Paleozoic (500-420 Ma) (Zhang J. et al., 2005a, 2006, 2008, 2010; 845 Yang et al., 2001, 2002, 2005; Song et al., 2003, 2005, 2006; Zhang G., 2008, 2009a, 846 Mattinson et al., 2006b, 2009). This is similar to the scenarios in typical collisional 847 orogens worldwide (e.g. Alps, Himalaya and Dabie-Sulu). The occurrence of HP 848 granulite is another characteristic of the SAT-NQD. At Bashiwake of the SAT and 849 Aercituoshan of the NQD, HP granulites ages are similar (ca. 485-500Ma at 850 Bashiwake, ca. 418-449Ma at Aercituoshan) to that of the adjacent UHP eclogites, 851 but experienced a higher peak temperature and lower peak pressure conditions. This 852 suggests that UHP eclogite and HP granulite formed in different thermal 853 environments at same time, i.e. the UHP eclogite formed in the subducted 854 continental crust in a relatively lower geothermal gradient $\left(6-10^{\circ} \mathrm{C} / \mathrm{km}\right)$, and the HP 855 granulite formed at the base of thickened crust of the overriding plate in a relatively 856 higher geothermal gradient $\left(15-18^{\circ} \mathrm{C} / \mathrm{km}\right)$ (Zhang J. et al., 2009c, 2014) (Fig. 17). 857 As discussed above, penecontemporaneous metamorphic ages but different 858 geothermal gradients between HP granulites and related UHP eclogite define a 859 possible paired metamorphic belt generated in a subduction-collision setting 860 associated with the continent collisional orogeny during early Paleozoic (Zhang J. et 
861 al., 2009c; 2014; Yu et al., 2011, 2012, 2014), similar to the more common classic 862 paired metamorphic belt in oceanic subduction orogens (accretion orogens), in which 863 an inboard high dT/dP metamorphic belt is juxtaposed against an outboard low 864 dT/dP metamorphic belt along a tectonic contact (Miyashiro, 1961; Brown, 2009). 865 Therefore, this type of paired metamorphic belt may be a diagnostic characteristic of 866 collisional orogens, consistent with the interpretation that the SAT-NQD is a typical collisional orogenic belt.

868 Moreover, as described above, in the SAT-NQD, almost all high grade 869 metamorphic rocks experienced a Barrovian type overprint although it remains 870 unclear that whether or not all Barrovian type rocks have an earlier (U)HP 871 metamorphic history. The regional Barrovian type metamorphism and syn-kinematic 872 granitoids with ages ranging from 460-440 Ma in the SAT (Zhang J. et al., 2000, 873 2011; Cao et al., 2010; Kang et al., 2013; Zhang J. et al. unpublished data), which 874 are about 30-50 Ma later than the formation ages of UHP eclogites (ca. 480-500 $875 \mathrm{Ma}$ ). In the NQD, although polymetamorphism leads to some geochronologic 876 ambiguity, chronologic data combined with petrographic evidence indicates that 877 low-medium-P metamorphism and associated magmatism (400-428 Ma) are about 878 20-30 Ma later than the UHP metamorphic times (423-460 Ma). This scenario may 879 be analogous to the Cenozoic situation of the Himalayan orogen, where UHP 880 eclogites and adjacent gneisses were formed at mantle depths $>100 \mathrm{~km}$ at 46 to 55 881 Ma, whereas the widely distributed Barrovian amphibolite- to granulite-facies 882 metamorphism and associated magmatism occurred at 30 to $15 \mathrm{Ma}$ (Liou et al., 2004 883 and references therein).

884 The discussions above indicate that accretionary orogeny and collisional orogeny 885 developed in the North Altun-North Qilian and South Altun-North Qaidam regions, 886 which are separated by the Qilian-Central Altun microcontinental block. In North 887 Altun-North Qilian, the metamorphic pattern defined by HP/LT metamorphism and 888 possible LP/HT metamorphism is consistent with an accretionary orogenic system 889 related to oceanic subduction. In contrast, in North Qaidam-South Altun, the 890 metamorphic pattern characterized by UHP metamorphism, HP granulite and 
Barrovian type metamorphism is characteristic of a collisional orogenic system. This implies that there were two parallel early Paleozoic orogens of distinct types side by side; the NAT-NQL accretionary orogen and the SAT-NQD collisional orogen, and both had extensive dimensions with lengths of some $1000 \mathrm{~km}$. The age differences of HP/LT metamorphism between the NAT and NQL, and UHP, HP granulite and Barrovian metamorphism between the SAT and NQD may demonstrate diachronous accretion and collisional orogenesis. This is unsurprising for an orogen with a scale of more than $1000 \mathrm{~km}$. Moreover, although debate remains, HP/LT metamorphism in the NAT-NQL and UHP metamorphism in the SAT-NQD generally developed synchronously. Therefore, they probably resulted from two independent subduction systems (e.g. Yang J.S. et al., 2002, Zhang G. et al., 2013), rather than from a single oceanic subduction-continental collision process (e.g. Song et al., 2006, 2014a). The detailed discussion on the tectonic evolution of Altun-Qilian-North Qaidam is outside the scope of this paper.

The NKL eclogites in the East Kunlun Mountains have similar field relationships (enclosed in continental gneiss) and mineral assemblage to the NQD eclogites, although their $\mathrm{P}-\mathrm{T}$ condition has not been well constrained. The present chronological data show that the NKL eclogites have a similar or slightly younger metamorphic age compared to the NQD eclogites; the NQD and NKL are separated by the Qaidam basin covered by Cenozoic sediments. The occurrence of similar continental type eclogites on two sides of the Qaidam basin make it necessary to reconsider the nature of the Qaidam block (i.e. basement of Qaidam basin), which was previously considered as a cratonic block consisting of Precambrian metamorphic rocks coherent with high grade metamorphic rocks in the NKL (BGMQ, 1991). Further detailed investigation is needed to determine the relationship between the NQD UHP eclogites and the newly recognized NKL eclogites. 


\section{Acknowledgments}

919 This work was financially supported by the National Natural Science Foundation of 920 China (Grant nos. 41572180, 41072151 and 41272210), the Ministry of Land and 921 Resources of China (No. 201011034), the Geological Survey Project of China (No. 922 12120114078301), and the U.S. National Science Foundation (EAR1347433). The 923 paper was substantially improved by the constructive reviews of two journal reviewers. We also thank for Guest Editor Z.M.Zhang amd Chief Editor M.Santosh for their invitation for submission to this Special issue of Gondwana Research.

\section{References}

Aoki, K., Windey, B.F., Maruyama, S., Omori, S., 2014. Metamorphic P-T conditions and retrograde path of high-pressure Barrovian metamorphic zones near Cairn Leuchan, Caledonian orogen, Scotland. Geological Magazine 151, 559-571.

Berger, A., Schmid, S.T., Engi, M., Bousquet, R. and Wiederkehr, M., 2011. Mechanisms of mass and heat transport during Barrovian metamorphism: A discussion based on field evidence from the Central Alps (Switzerland/northern Italy). Tectonics 30, TC1007, doi: 10.1029/2009TC002622.

Brown, M., 2006. A duality of thermal regimes is the distinctive characteristic of plate tectonics since the Neoarchean. Geology 34, 961-964.

Brown, M., 2007. Metamorphic conditions in orogenic belts: A record of secular change. International Geology Review 49, 193-234.

Brown, M., 2008. Characteristic thermal regimes of plate tectonics and their metamorphic imprint throughout Earth history: when did Earth first adopt a plate tectonics mode of behavior? In: Condie, K., Pease, V. (Eds.), When Did Plate Tectonics Begin? Geological Society of America 
$943 \quad$ Special Paper, vol. 440, pp. 97-128.

944 Brown, M., 2009. From: Earth Accretionary Systems in Space and Time. In: Cawood, P. A. and 945 Kroner, A. (eds). The Geological Society, London, Special Publications 318, 37-74.

946 Brown, M., 2010. Paired metamorphic belts revisited. Gondwana Research 18, 46-59.

947 Bureau of Geology and Mineral Resources Qinghai Province (BGMQ), 1991. Regional geology of 948 Qinghai Province. Geological Publishing House, China, pp. 315- 318 (in Chinese with English 949 abstract).

950 Bureau of Geology and Mineral Resources of Xinjiang Uygur Autonomous Region (BGMX), 951 1993. Regional Geology of Xinjiang Uygur Autonomous Region. Geological Publishing House, 952 Bejing China, pp. 315-318 (in Chinese with English abstract).

953 Cao, Y.T., Liu, L., Wang, C., Yang, W.Q., Zhu, X.H., 2010. Geochemical, zircon U-Pb dating 954 and Hf isotope composition studies for Tatelekebulake granite in south Altyn Tagh. Acta Petrologica Sinica 26, 3259-3271.

956 Carswell, D.A., O'Brien, P.J., 1993. Thermobarometry and geotectonic significance of high 957 pressure granulites: examples from the Moldanubian Zone of the Bohemian Massif in Lower $958 \quad$ Austria. Journal of Petrology 34, 427-459.

959 Chang, C.F., Chen, N., Coward, M.P., Deng, W.M., Dewey, J.F., Gansser, A., Harris, B.W., Kidd, 960 W.S.F., Leeder, M.R., Li, H., Lin, J., Liu, C., Mei, H., Molnar, P., Pan, Y., Pearce, J.A., 961 Shackleton, R.M., Smith, A.B., Sun, Y., Ward, M., Watts, D.R., Xu, J., Xu, R., Yin, J., Zhang, 962 Y., 1986. Preliminary conclusions of the royal society and academia sinica 1985 geotraverse of 963 Tibet. Nature 323, 501-507.

964 Chen, D.L., Liu, L., Sun, Y., Liou, J.G., 2009. Geochemistry and zircon U-Pb dating and its 965 implications of the Yukahe HP/UHP terrane, the North Qaidam, NW China. Journal of Asian 966 Earth Sciences 35, 259-272.

967 Chen, N.S., Li, X.Y., Wang, X.Y., Chen, Q., Wang, Q.Y., Wan, Y.S., 2006. Zircon SHRIMP $968 \mathrm{U}-\mathrm{Pb}$ age of Neoproterozoic metagranite in the North Kunlun unit on the southern margin of 969 the Qaidam block in China. Geological Bulletin of China 25, 1311-1314 (in Chinese with $970 \quad$ English abstract).

971 Chen, N.S., Sun, M., Wang, Q.Y., Zhao, G.C., Chen, Q., Shu, G.M., 2007. EMP chemical ages of 972 monazites from Central Zone of the eastern Kunlun Orogen: records of 
multi-tectonometamorphic events. Chinese Science Bulletin 52, 2252-2263.

Chen, N.S., Liao F.X., Wang L., Santosh, M., Sun M., Wang, Q.Y., Mustafa, H.A., 2013. Late Paleoproterozoic multiple metamorphic events in the Quanji Massif: Links with Tarim and North China Cratons and implications for assembly of the Columbia supercontinent. Precambrian Research 228, 102- 116.

Chopin, C., 1984. Coesite and pure pyrope in high-grade blueschists of the western Alps: a first record and some consequences. Contributions to Mineralogy and Petrology 86, 107-118.

Christensen, B.D.J., 2011, Geochemistry, geothermobarometry and geochronology of high-pressure granulites and implications for the exhumation history of ultrahigh-pressure terranes: Dulan, Western China [MS thesis]: Central Washington University, 152 p.

Coleman, R.G., Wang, X., 1995. Overview of the geology and tectonics of UHPM. In R.G. Coleman and X. Wang, Eds., Ultrahigh Pressure Metamorphism, p. 1-32. Cambridge University Press, New York.

Coney, P., Jones, D.L., Monger, J.W.H., 1980. Cordilleran suspect terranes. Nature 288, 329-333.

Coney, P.J., 1992. The Lachlan belt of eastern Australia and circum-Pacific tectonic evolution. Tectonophysics 214, 1-25.

Dewey, J.F., Shackleton, R., Chang, C.F., Sun, Y., 1988. The tectonic evolution of the Tibetan Plateau. Philosophical Transactions of the Royal Society, London A327, 379-413.

Deway, J. F., Bird, J.M., 1970. Mountain belts and the new global tectonics. Journal of Geophysical Research 75, 2625-47.

Dilek, Y., Moores, E.M., 1999. A Tibetan model for the early tertiary western United States. Journal of the Geological Society, London 156, 929-941.

Gebauer, D., Schertl, H.P., Brix, M., Schreyer, W., 1997. 35 Ma old ultrahigh-pressure metamorphism and evidence for very rapid exhumation in the Dora-Maira massif, Western Alps. Lithos 41, 5-24.

Gehrels, G.E., Yin, A., Wang, X.F., 2003a. Detritalzircon geochronology of the northeastern Tibetan plateau. Geological Society of America Bulletin 115, 881-896.

Gehrels, G.E., Yin, A., Wang, X.F., 2003b. Magmatic history of the northeastern Tibetan Plateau. Journal of Geophysical Research 108, 2423. http://dx.doi.org/ 10.1029/2002JB001876.

Gehrels, G.E., Kapp, P., DeCelles, P., Pullen, A., Blakey, R., Weislogel, A. Ding, L., Guynn, J., 
Martin, A., McQuarrie, N., Yin, A., 2011. Detrital zircon geochronology of pre- Tertiary strata in the Tibetan- Himalayan orogen. Tectonics 30, TC5016, doi:10.1029/2011TC002868.

Godard, G., Mabit, J.L., 1998. Peraluminous sapphirine formed during retrogression of a kyanite bearing eclogite from Pays de Leon, Armorican Massif, France. Lithos 43, 15-29.

Gong, S.L., Chen, N.S., Wan, Q.Y., Kusky, T.M., Wang, L., Zhang, L., Ba, J., Liao, F.X., 2012. Early Paleoproterozoic Magmatism in the Quanji Massif, northeastern margin of the Qinghai-Tibet Plateau and its tectonic significance: LA-ICPMS U-Pb Zircon age and geochemistry constraints. Gondwana Research 21, 152-166.

England, P.C., Thompson, A.B., 1984. Pressure-temperature-time paths of regional metamorphism. I. Heat transfer during regions of thickened continental crust. Journal of Petrology 25, 894-928.

Ernst, W.G., 2005. Apline and Pacific styles of Phanerozoic mountain building: subduction-zone petrogenssis of continental crust. Terra Nova 17, 165-188.

Ernst, W.G., 2010. Subduction-zone metamorphism, calc-alkaline magmatism, and convergent-margin crustal evolution. Gondwana Research 18, 8-16.

He, D.F., Dong, Y.P., Liu, X.M., Yang, Z., Sun, S.S., Chen, B., Li, W., 2015. Tectono-thermal events in East Kunlun, Northern Tibetan Plateau: Evidence from zircon U-Pb geochronology, Gondwana Research, http://dx.doi.org/10.1016/j.gr.2015.08.002.

Huang, H., Niu, Y.L., Nowell, G., Zhao, Z.D., Yu, X.H., Mo, X.X., 2015. The nature and history of the Qilian Block in the context of the development of the Greater Tibetan Plateau. Gondwana Research 28, 209-224.

Jolivet, L., Faccenna, C., Goffé, B., Burov, E., Agard, P., 2003. Subduction tectonics and exhumation of high-pressure metamorphic rocks in the Mediterranean orogens. American Journal of Science 303, 353-409

Jahn, B.M., 2001. The third workshop of IGCP-420 (continental growth in the Phanerozoic: evidence from Central Asia). Episodes 24, 272-273.

Jahn, B.M., Windley, B., Natal'in, B., Dobretsov, N., 2004. Phanerozoic continental growth in Central Asia. Journal of Asian Earth Sciences 23, 599-603.

Keay, S., Lister, G., Buick, I., 2011. The timing of partial melting, Barrovian metamorphism and granite intusion in Naxos metamorphic core complex, Cyclades, Aegean Sea, Greece. 
Kang, L., Liu, L., Cao, Y.T., Wang, C., Yang, W.C., Liang, S., 2013. Geochemistry, zircon U-Pb age and its geological significance of the gneissic granite from the eastern segment of the Tatekebulake composite granite in the south Altyn Tagh. Acta Petrologica Sinica 29, 3039-3048.

Kang, L., Xiao, F.X., Gao, X.F., Xi, R.G., Yang, Z.C., 2015. Age, petrogenesis and tectonic implications of Early Devonian bimodal volcanic rocks in the South Altyn, NW China. Journal of Asian Earth Sciences 111, 733-750.

Ker, C.M., Yang, H.J., Zhang, J.X., Shau, Y.H., Chieh, C.J., Meng, F.C., Takazawa, E., You, C.F., 2015. Compositional and $\mathrm{Sr}-\mathrm{Nd}-\mathrm{Hf}$ isotopic variations of Baijingsi eclogites from the North Qilian orogen, China: Causes, protolith origins, and tectonic implications. Gondwana Research $28,721-734$

Konopasek, J, Schulmann, K., 2005. Contrasting Early Carboniferous field geotherms: evidence for accretion of a thickened orogenic root and subducted Saxothuringian crust (Central European Variscides). Journal of the Geological Society, London 162, 463-470.

Kotková, J., 2007. High-pressure granulites of the Bohemian Massif: recent advances and open questions. Journal of Geosciences 52, 45-71.

Li, H.K., Lu, S.N., Xiang, Z.Q., Zhou, H.Y., Guo, H., Song, B., Zheng, J.K., Gu, Y., 2006. SHRIMP U-Pb zircon age of the granulite from the Qingshuiquan area, Central Eastern Kunlun Suture Zone. Earth Science Frontiers 13, 311-321 (in Chinese with English abstract).

Li, Y. S., Zhang, J. X., Yu, S. Y., Li, S.Y., Gong, J.H., 2015. Origin of Early Paleozoic garnet peridotite and associated garnet pyroxenite in the south Altyn Tagh, NW China: Constraints from geochemistry, SHRIMP U-Pb zircon dating and Hf isotopes. Journal of Asian Earth Sciences 100, 60-77.

Liao, F.X., Zhang, L., Chen, N.S., Sun, M., Santosh, M., Wang, Q.Y., Mustafa, H. A., 2016. Geochronology and geochemistry of meta-mafic dykes in the QuanjiMassif, NW China: Paleoproterozoic evolution of the Tarim Cratonand implications for the assembly of the Columbia supercontinent. Precambrian Research 249, 33-56.

Lin, Y.H., Zhang, L.F., Ji, J.Q., Song, S.G., 2010. 40Ar/39Ar age of Jiugequan lawsonite blueschists in northern Qilian Mountains and its petrologic significance. Chinese Science 
1079

1080

Bulletin 55, 2021-2027.

Liou, J.G., Wang, X.M., Coleman, R.G., Zhang, Z.M., Maruyama, S., 1989. Blueschists in major suture zones China. Tectonics 8, 609-619.

Liou, J. G., Tsujimori, T., Zhang, R. Y., Katayama, I., Maruyam, S. 2004. Global UHP metamorphism and continental subduction/collision: the Himalayan model. International Geology Review 46, 1-27.

Liu, L., Che, Z., Luo, J., Wang, Y., Gao, Z., 1996. Recognition and implication of eclogite in the western Altun Mountains, Xinjiang. Chinese Science Bulletin 41, 1485-1488 (in Chinese).

Liu. L., Sun, Y., Xiao. P.X., Che, Z.C., Luo, J.H., Chen, D.L., Wang, Y., Zhang, A.D., Chen, L., 2002. Discovery of ultrahighpressure magnesite-bearing garnet lherzolite (>3.8 GPa) in the Altyn Tagh, Northwest China. Chinese Science Bulletin 47, 881-886.

Liu, L., Wang, C., Cao, Y.T., Chen, D.L.,,2012. Geochronology of multi-stage metamorphic events: Constraints on episodic zircon growth from the UHP eclogite in the South Altyn, NW China. Lithos 136-139, 10-26.

Liu, L., Wang, C., Chen, D.L., Zhang, A.D., Liou, J.G., 2009. Petrology and geochronology of HP-UHP rocks from the South Altyn, northwestern China. Journal of Asian Earth Sciences 35, 232-244.

Liu, X.C., Jahn, B.M., Liu, D.Y., Dong, S.W., Li, S.Z., 2004. SHRIMP U-Pb zircon dating of a metagabbro and eclogites from western Dabieshan (Hong'an block), China, and its tectonic implications. Tectonophysics 394, 171-192.

Liu, Y.C., Li, S.G., Xu, S.T., 2007. Zircon SHRIMP U-Pb dating for gneisses in northern Dabie high T/P metamorphic zone, central China: Implications for decoupling within subducted continental crust. Lithos 96, 170-185.

Liu, F.L., Gerdes, A., Xue, H.M., 2009. Differential subduction and exhumation of crustal slices in the Sulu HP-UHP metamorphic terrane: Insights from mineral inclusions, trace elements, $\mathrm{U}-\mathrm{Pb}$ and $\mathrm{Lu}-\mathrm{Hf}$ isotope analyses of zircon in orthogneiss. Journal of Metamorphic Geology 27, $805-825$.

Liu, X.C., Jahn, B.M., Cui, J.J., Li S.Z., Wu, Y.B., Li, X.H., 2010. Triassic retrograded eclogites and Cretaceous gneissic granites in the Tongbai Complex, central China: Implications for the architecture of the HP/UHP Tongbai-Dabie-Sulu collision zone. Lithos, 119, 211-237. 
Liu, X.C., Jahn, B.M., Li, S.Z., 2013. Diachroneity of continental subduction and exhumation: constraints from the Permian-Triassic HP metamorphic terrane in the Tongbai orogen, central China. Chinese Science Bulletin 58, 4397-4404.

Liu, Y., Zhong, D., 1997. Petrology of high-pressure granulites from the eastern Himalayan syntaxis. Journal of Metamorphic Geology 15, 451-466.

Liu, Y. J., Neubauer, F., Genser, J., 2006. 40Ar/39Ar ages of blueschist facies politic schists from Qingshuigou in the Northern Qilian Mountain, western China. Island Arc 15, 187-198.

Lu, S.N., Yu, H.F., Li, H.K., Guo, K.Y., Wang, H.C., Jin, W., Zhang, C.L., Liu, Y.S., 2006. Research on Precambrian Major Problems in Chinese. Geological Publishing House, Beijing, pp. 1-197 (in Chinese).

Lu, S.N., Li, H.K., Zhang, C.L., Niu, G.H., 2008. Geological and geochronological evidence for the Precambrian evolution of the Tarim craton and surrounding continental fragments. Precambrian Research 160, 94-107.

Lv, Z., Zhang, L., Du, J. Bucher, K., 2008. Coesite inclusions in garnet from eclogitic rocks in western Tianshan, northwest China: Convincing proof of UHP metamorphism. American Mineralogist, 93, 1845-1850

Maruyama, S., Masago, H., Katayama, I., Iwase, Y., Toriumi, M., Omori, S., Aoki, K., 2010. A new perspective on metamorphism and metamorphic belts. Gondwana Research 18, 106-137.

Matsuda, T., Isozaki, Y., 1991. Well-documented travel history of Mesozoic pelagic cherts in Japan: from remote ocean to subduction zone. Tectonics 10, 475-499.

Matte, P., Tapponnier, P., Arnaud, N., Bourjot, L., Avouac, J.P., Vidal, P., Liu, Q., Pan, Y., Wang, Y., 1996. Tectonics of Western Tibet, between the Tarim and the Indus. Earth and Planetary Science Letters 142, 311-330.

Mattinson, C.G., Wooden, J.L., Liou, J.G., Bird, D.K., Wu, C.L., 2006a Age and Duration of Eclogite-facies Metamorphism, North Qaidam HP/UHP Terrane, Western China. American Journal of Science 306, 683-711

Mattinson, C.G., Wooden, J.L., Liou, J.G., Bird, D.K., Wu, C.L., 2006b, Geochronology and tectonic significance of Middle Proterozoic granitic orthogneiss,North Qaidam HP/UHP terrane, Western China. Mineralogy and Petrology 88, 227-241.

Mattinson, C.G., Menold, C.A., Zhang, J.X, Bird, D.K., 2007. High and ultrahigh-pressure 
metamorphism in the North Qaidam and South Altyn terranes, Western China. International Geology Review 49, 969-995.

Meng, F.C., Zhang, J.X., Yang, J.S., 2005. Tectono-thermal event of post-HP/UHP metamorphism in Xitieshan area of the North Qaidam Mountains, western China: isotopic and geochemical evidence of granite and gneiss. Acta Petrologica Sinica 21, 45-56 (In Chinese with English abstract).

Meng, F.C., Zhang, J.X., Cui, M.H., 2013. Discovery of Early Paleozoic eclogite from the East Kunlun, Western China and its tectonic significance. Gondwana Research 23, 825-836.

Metcalfe, I., 2013. Gondwana dispersion and Asian accretion: Tectonic and palaeogeographic evolution of eastern Tethys. Journal of Asian Earth Sciences 66, 1-33.

Miller, C., Mundil, R., Thöni, M., 2005. Refining the time of eclogite metamorphism: A geochemical, petrological, $\mathrm{Sm}-\mathrm{Nd}$ and $\mathrm{U}-\mathrm{Pb}$ case study from the Pohorje Mountains, Slovenia (Eastern Alps). Contributions to Mineralogy and Petrology 150, 70-84.

Miyashiro, A., 1961. Evolution of metamorphic belts. Journal of Petrology 2, 277-311.

O'Brien, P.J., 2008. Challenges in high-pressure granulite metamorphism in the era of pseudosections: reaction textures, compositional zoning and tectonic interpretation with examples from the Bohemian Massif. Journal of Metamorphic Geology 26, 235-251.

O'Brien P.J., Rötzler J., 2003. High-pressure granulites: formation, recovery of peak conditions and implications for tectonics. Journal of Metamorphic Geology 21, 3-20.

Ota, T., Kaneko, Y., 2010. Blueschists, eclogites, and subduction zone tectonics: Insights from a review of Late Miocene blueschists and eclogites, and related young high-pressure metamorphic rocks. Gondwana Research 18, 167-188.

Pan, G.T., Wang, L.Q., Li, R.S., Yuan, S.H., Ji, W.H., Yin, F.G., Zhang, W.P., Wang, B.D., 2012. Tectonic evolution of the Qinghai-Tibet Plateau. Journal of Asian Earth Sciences 53, 3-14.

Proyer, A., 2003. The preservation of high-pressure rocks during exhumation: metagranites and metapelites. Lithos 70, 183-194.

Qi, S.S., Song, S.G., Shi, L.C., Cai, H.J., Hu, S.C., 2014. Discovery and its geological significance of early Paleozoic eclogite in Xiarihamu-Suhaitu area, western part of the east Kunlun. Acta Petrologica Sinica, 30, 3345-3356.

Reinecke, T., 1991. Very-high-pressure metamorphism and uplift of coesite-bearing 

metasediments from the Zermatt-Saas zone, Western Alps. European Journal of Mineralogy 3, $7-17$.

Rotzler, J., Romer, R.L., 2001. P-T-t evolution of ultrahigh temperature granulite from the Saxon Granulite Massif, Germany, part I: petrology. Journal of Petrology 42, 1995-2013.

Rubatto, D., Gebauer, D., Compagnoni, R., 1999. Dating of eclogite-facies zircons: The age of Alps metamorphism in the Sesia-Lanzo Zone (Western Alps). Earth and Planetary Science Letters $167,141-158$

Sengor, A.M.C., 1987. East Asia tectonic collage. Nature, 318, 16-17.

Sengor, A.M.C., Natal'in, B.A., Burtman, U.S., 1993. Evolution of the Altaid tectonic collage and Paleozoic crustal growth in Eurasia. Nature 364, 209-304.

Sengor, A.M.C., Natal'in, B., 1996. Turkic-type orogeny and its role in the making of the continental crust. Annual Reviews of Earth and Planetary Sciences 24, 263-337.

Smith, D.C., 1984. Coesite in clinopyroxene in the Caledonides and its implications for geodynamics. Nature 310, 641-644.

Song, S.G., Yang, J.S, Xu, Z.Q, Liou, J.G, Shi, R.D., 2003. Metamorphic evolution of the coesite-bearing ultrahigh-pressure terrane in the north Qaidam, northern Tibet, NW China. Journal of metamorphic Geology 21, 631-644.

Song, S.G., Zhang, L.F., Niu, Y.L., 2004. Zircon U-Pb SHRIMP ages of eclogites from the North Qilian Mountain in NW China and their tectonic implication. Chinese Science Bulletin 49, 848-852.

Song, S.G., Zhang, L.F., Niu, Y.L. Su, L, Jian, P., Liu, D., 2005. Geochronology of diamond-bearing zircons from garnet peridotite in the North Qaidam UHPM belt, Northern Tibetan Plateau: A record of complex histories from oceanic lithosphere subduction to continental collision. Earth and Planetary Science Letters 234, 99-118.

Song, S.G., Zhang, L.F., Niu, Y.L. Li, S., Song, B., Liu, D.Y., 2006. Evolution from oceanic subduction to continental collision: A case study of the Northern Tibetan Plateau inferred from geochemical and geochronological data. Journal of Petrology 47, 435-455

Song, S.G., Zhang, L.F., Niu, Y.L. Wei, C.J., Liou, J.G., Shu, G.M., 2007. Eclogite and carpholite-bearing metasedimentary rocks in the North Qilian suture zone, NW China: implications for Early Palaeozoic cold oceanic subduction and water transport into mantle. 

Journal of Metamorphic Geology 25, 547-563.

Song, S.G., Su, L., Li, X.H., Zhang, G.B., Niu, Y.L., Zhang, L.F., 2010. Tracing the $850 \mathrm{Ma}$ continental flood basalts from a piece of subducted continental crust in the North Qaidam UHPM belt, NW China. Precambrian Research 183, 805-816.

Song, S.G., Niu, Y.L., Su, L.,Xia X.H., 2013. Tectonics of the North Qilian orogen, NW China, Gondwana Research 23, 1378-1401.

Song, S.G., Niu, Y.L., Su, L., Zhang, C., Zhang, L.F., 2014a. Continental orogenesis from ocean subduction, continent collision/subduction, to orogen collapse, and orogen recycling: The example of the North Qaidam UHPM belt, NW China. Earth-Science Reviews 129, 59-84

Song, S.G., Niu, Y.L., Su, L., Wei, C.J., Zhang, L.F., 2014b. Adakitic (tonalitic-trondhjemitic) magmas resulting from eclogite decompression and dehydration melting during exhumation in response to continental collision. Geochimica et Cosmochimica Acta 130, 42-62

Spurlin, M.S., Yin, A., Horton, B.K., Zhou, J., Wang, J., 2005. Structural evolution of the Yushu-Nangqian region and its relationship to syncollisional igneous activity, east-central Tibet. Geological Society of America Bulletin 117, 1293-1317.

Stamfli, G.M., Hochard, C., Vérard, C., Wilhem, C., von-Raumer, J., 2013. The formation of Pangea. Tectonophysics 593, 1-19.

Tapponnier, P., Xu, Z., Roger, F., Meyer, B., Arnaud, N., Wittlinger, G., Yang, J., 2001. Oblique stepwise rise and growth of the Tibet Plateau. Science 294, 1671-1677.

Teyssier C. and Whitney D.L., 2002. Gneiss dome and Orogen. Geology 30, 1139-1142.

von Raumer, J.F., Stampfl, G.M., 2008. The birth of the Rheic Ocean - Early Palaeozoic subsidence patterns and subsequent tectonic plate scenarios. Tectonophysics 461, 9-20

Tung, K.A., Yang, H.J., Yang, H.Y., Liu, D.Y., Zhang, J.X., Wan, Y.S., Tseng, C.Y., 2007. SHRIMP U-Pb geochronology of the zircons from the Precambrian basement of the Qilian Block and its geological significances. Chinese Science Bulletin 52, 2687-2701.

Tung, K.A., Yang, H.Y., Liu, D.Y., Zhang, J.X., Yang, H.J., Shau, Y.H., Tseng, C.Y., 2012. The amphibolite-facies metamorphosed mafic rocks from the Maxianshan area, Qilian block, NW China: a record of early Neoproterozoic arc magmatism. Journal of Asian Earth Sciences 46, $177-189$.

Tung, K.A., Yang, H.Y., Liu, D.Y., Zhang, J.X., Yang, H.J., Shau, Y.H., Tseng, C.Y., 2012. The 

Neoproterozoic granitoids from the Qilian block, NW China: Evidence for a link between the Qilian and South China block. Precambrian Research 235, 163- 189

Walsh, E.O., Hacker, B.R., 2004. The fate of subducted continental margins: Two-stage exhumation of the high pressure to ultrahigh-pressure western Gneiss Region, Norway. Journal of Metamorphic Geology 22, 671-687

Wan, Y.S., Xu, Z.Q., Yan, J.S., Zhang, J.X., 2001. Ages and compositions of the Precambrian high-grade basement of the Qilian Terrane and its adjacent areas. Acta Geologica Sinica 75, 375-384.

Wan, Y.S., Zhang, J.X., Yang, J.S., Xu, Z.Q., 2006. Geochemistry of high-grade metamorphic rocks of the North Qaidam mountains and their geological significance. Journal of Asian Earth Sciences 28, 174-184.

Wang, C., Liu, L., Chen, D.L., Cao, Y.T., 2011. Petrology, geochemistry, geochronology and metamorphic evolution of garnet peridotites from South Altyn UHP terrane, NW China: Records related to crustal slab subduction and exhumation history. In: Dobrzhinetskaya, L., Cuthbert, S., Faryad, W., Wallis, S. (Eds.), UHPM: 25 years after discovery of coesite and diamond. Elsevier, pp. 541-577.

Wang, C., Liu, L., Yang,W.Q., Zhu, X.H., Cao, Y.T., Kang, L., Chen, S.F., Li, R.S., He, S.P., 2013. Provenance and ages of the Altyn Complex in Altyn Tagh: implications for the early Neoproterozoic evolution of northwestern China. Precambrian Research 230, 193-208

Wang, G.C., Wang, Q.H., Jian, P., Zhu, Y.H., 2004. Zircon SHRIMP ages of Precambrian metamorphic basement rocks and their tectonic significance in the eastern Kunlun Mountains, Qinghai Province, China. Earth Science Frontiers 11, 481-490 (in Chinese with English abstract).

Wang, G.C., Wei, Q.R., Jia, C.X., Zhang, K.X., Li, D.W., Zhu, Y.H., Xiang, S.Y., 2007. Some ideas of Precambrian geology in the East Kunlun, China. Geological Bulletin of China 26, 929-937 (in Chinese with English abstract).

Wang, M.J., Song, S.G., Niu, Y.L., Su, L., 2014. Post-collisional magmatism: Consequences of UHPM terrane exhumation and orogen collapse, N. Qaidam UHPM belt, NW China. Lithos 210-211, 181-198.

Wang, X.X., Wang, T., Castro, A., Hu, N.G., 2015. Gondwana Research 18, 8-16. Proterozoic 
rapakivi granites from the North Qaidam orogen, NW China:Implications for basement attribution. Gondwana Research 28, 1516-1529.

Wang, Y.S., Chen, J.N., 1987. Metamorphic Zone and Metamorphism in Qinghai Province and its Adjacent Areas. Geological Publishing House, Beijing, pp. 1-248 (in Chinese with English abstract).

Wei, C.J., Song, S.G., 2008. Chloritoid-glaucophane schist in the north Qilian orogen, NW China: phase equilibria and P-T path from garnet zonation. Journal of Metamorphic Geology 26, 301-316

Windley, B.F., Alexeiev, D., Xiao, W., Kröner, A., Badarch, G., 2007. Tectonic models for accretion of the Central Asian Orogenic belt. Journal of the Geological Society, London 164, $31-47$.

Winter, J. D. 2001. An Introduction to Igneous and Metamorphic Petrology, 697 pp., Prentice Hall, Upper Saddle River, N. J. Whitney, D.L., Teyssier, C., Fayon, A.K., Hamilton, M.A., Heizler, M., 2003. Tectonic controls on metamorphism, partial melting, and intrusion: timing and duration of regional metamorphism and magmatism in the Nigde Massif, Turkey. Tectonophysics 376, 37-60.

Whitney, D.L., Evans B.W., 2010. Abbreviations for names of rock-forming minerals. American Mineralogist 95, 185-187.

Wiederkehr, M., Bousquet, S.M., Schmid, A., 2008. From subduction to collision: Thermal overprint of HP/LT metasediments in the north-eastern Lepontine Dome (Swiss Alps) and consequences regarding the tectonometamorphic evolution of the Alpine orogenic wedge. Swiss Journal of Geosciences101, 127-155.

Wu, C.L., Gao, Y.H., Frost, R., Robinson, P.T., Wooden, J.L., Wu, S.P., Chen, Q.L., Lei, M., 2009. An Early Paleozoic double-subduction model for the North Qilian oceanic plate: evidence from zircon SHRIMP dating of granites. International Geology Review 53, 157-181.

Wu, H.Q., Feng, Y.M., Song, S.G., 1993. Metamorphic and deformation of blueschist belts and their tectonic implications, North Qilian Mountains, China. Journal of Metamorphic Geology 11, 523-536.

Xiao, X.C., Chen, G.M., Zhu, Z.Z., 1978. A preliminary study on the tectonics of ancient ophiolites in Qilian Mountains, Northwest China. Acta Geologica Sinica 52, 287-295. 
Xiao, W.J., Han, C.M., Yuan, C., Chen, H.L., Sun, M., Lin, S.F., Li, Z.L., Mao, Q.G., Zhang,J.E., Sun, S., Li, J.L., 2006. The unique Carboniferous-Permian tectonic metallogenic framework of northern Xinjiang (NW China): constraints for the tectonics of the southern Paleoasian Domain. Acta Petrologica Sinica 22, 1362-1376.

Xiao, W.J., Windley, B.F, Yong, Y., Yan, Z., Yuan, C., Liu, C.Z., Li, J.L., 2009. Early Paleozoic to Devonian multiple-accretionary model for the Qilian Shan, NW China. Journal of Asian Earth Sciences 35, 323-333.

Xia, L.Q., Xia, Z.C., Xu, X.Y., 2003. Magmageneisis in the Ordovician in back basins of the northern Qilian Mountains, China. Geological Society of America Bulletin 115, 1510-1522.

Xiong, Q., Zheng, J.P., Griffin,W.L., O'Reilly, S.Y., Zhao, J.H., 2011. Zircons in the Shenglikou ultrahigh-pressure garnet peridotite massif and its country rocks from the North Qaidam terrane (western China): Meso-Neoproterozoic crust-mantle coupling and early Paleozoic convergent plate-margin processes. Precambrian Research 187, 33-57.

Xiong, Q, Zheng, J.P., Griffin, W.L., O'Reilly, S.Y., Pearson, N.J., 2012.Decoupling of U-Pb and $\mathrm{Lu}-\mathrm{Hf}$ isotopes and trace elements in zircon from the UHP North Qaidam orogen, NE Tibet (China): Tracing the deep subduction of continental blocks. Lithos 155, 125-145.

Xu, W.C., Zhang, H.F., Liu, X.M., 2007. U-Pb zircon dating constraints on formation time of Qilian high-grade metamorphic rock and its tectonic implications. Chinese Science Bulletin 52, $531-538$.

Xu, Z.Q., Xu, H.F., Zhang, J.X., Li, H.B., Zhu, Z.Z., Qu, J.C., Chen, D.Z., Yang, K.C., 1994. The Zhoulang Nanshan Caledonian subduction complexes in the northern Qilian Mountains and its dynamics. Acta Geologica Sinica 68, 1-15.

Xu, Z.Q., Yang, J.S., Zhang, J.X., Jiang, M., Li, H.B., Cui, J.W., 1999. A comparison between the tectonic units on the two sides of the Altun sinistral strike-slip fault and the mechanism of lithospheric shearing. Acta Geol Sin 73, 193-205 (in Chinese with English abstract).

Xu, Z.Q., Yang, J.S., Wu, C.L., Li, H.B., Zhang, J.X., Qi, X.X., Song, S.G., Qiu, H. J., 2006. Timing and Mechanism of Formation and Exhumation of the Northern Qaidam Ultrahigh-Pressure Metamorphic Belt. Journal of Asian Earth Sciences 28, 160-173.

Yang, J.J., Deng, J.F., 1994. Garnet peridotite and eclogites in the northern Qaidam Mountains, Tibetan plateau: a first record on UHP Metamorphism and Tectonics, II.P Task Group III-6, 

Stanford, A-20.

Yang, J.J., Powell, R., 2008. Ultrahigh-pressure garnet peridotites from the devolatilization of sea-floor hydrated ultramafic rocks. Journal of metamorphic Geology 26, 695-716

Yang, J.S., Xu, Z.Q., Li, H.B., Wu, C.L., Cui, J.W., Zhang, J.X., Chen, W., 1998. Discovery of eclogite at northern margin of Qaidam basin, NW China. Chinese Science Bulletin 43, $1755-1760$.

Yang, J.S., Xu, Z.Q., Song, S.G., Zhang, J.X., Wu, C.L., Shi, R.D., Li, H.B., Brunel, M., 2001. Discovery of coesite in the north Qaidam early palaeozoic ultrahigh pressure (UHP) metamorphic belt, NW China. Sciences de la Terre et des Planetes 333, 719-724.

Yang, J.S., Xu, Z.Q, Zhang, J.X., Song, S.G., Wu, C.L., Shi, R.D., Li, H.B., Brunel, M., 2002. Early Palaeozoic North Qaidam UHP metamorphic belt on the north-eastern Tibetan plateau and a paired subduction model. Terra Nova 14, 397-404.

Yang, J.S., Liu, F.L., Wu, C.L., Wan, Y.S., Zhang, J.X., Shi, R.D., Chen, S.Y., 2003. Two ultra-high pressure metamorphic events recognized in the central orogenic belt of China: evidence from the U-Pb dating of coesite-bearing zircons. Acta Geologica Sinica 77, 463-477 (in Chinese with English abstract).

Yang, J.S., Liu, F., Wu, C., Xu, Z., Shi, R., Chen, S., Deloule, E., Wooden, J.L., 2005. Two ultrahigh-pressure metamorphic events recognized in the central orogenic belt of China: evidence from the $\mathrm{U}-\mathrm{Pb}$ dating of coesite-bearing zircons. International Geology Review 47, $327-343$.

Yang, J.S., Wu, C.L., Zhang, J.X., Shi, R.D., Meng, F.C., Wooden, J., Yang, H.Y., 2006. Protolith of eclogites in the North Qaidam and Altun UHP terrane, NW China: earlier oceanic crust? Journal of Asian Earth Sciences 28, 185-204.

Yin, A., Manning, C. E., Lovera, O., Menold, C. A., Chen, X. \& Gehrels, G. E., 2007. Early Paleozoic tectonic and thermomechanical evolution of ultrahigh-pressure (UHP) metamorphic rocks in the northern Tibetan Plateau, northwest China. International Geology Review 49, $681-716$.

Yu, S.Y., Zhang J.X., Del Real P.G., 2011. Petrology and P-T path of high-pressure granulite from the Dulan area, North Qaidam Mountains, northwestern China. Journal of Asian Earth Sciences 42, 641-660, 
Yu, S.Y., Zhang J.X., Del Real, P.G., 2012. Geochemistry and zircon U-Pb ages of adakitic rocks from the Dulan area of the North Qaidam UHP terrane, north Tibet: Constraints on the timing and nature of regional tectonothermal events associated with collisional orogeny. Gondwana Research 21, 167-179.

Yu, S.Y., Zhang J.X., Li H.K., Hou K.J., Mattinson C.G., Gong J.H., 2013. Geochemistry, zircon $\mathrm{U}-\mathrm{Pb}$ geochronology and $\mathrm{Lu}-\mathrm{Hf}$ isotopic composition of eclogites and their host gneisses in the Dulan area, North Qaidam UHP terrane: New evidence for deep continental subduction, Gondwana Research 23, 901-919.

Yu, S.Y., Zhang, J.X., Mattinson, C.G., Del Real, P.G., Li, Y.S., Gong, J.H., 2014. Paleozoic HP granulite-facies metamorphism and anatexis in the Dulan area of the North Qaidam UHP terrane, western China: constraints from petrology, zircon $\mathrm{U}-\mathrm{Pb}$ and amphibole $\mathrm{Ar}-\mathrm{Ar}$ geochronology. Lithos 198, 58-76.

Yu, S.Y., Zhang J.X., Sun D.Y., Pablo García del Real, Li Y. S., Zhao X.L., Hou K.J., 2015. Petrology, geochemistry, zircon $\mathrm{U}-\mathrm{Pb}$ dating and $\mathrm{Lu}-\mathrm{Hf}$ isotope of granitic leucosomes within felsic gneiss from the North Qaidam UHP terrane: Constraints on the timing and nature of partial melting. Lithos 218-219, 1-21.

Zhang, C., Zhang L.F., Roermund, H.V., Song, S.G., Zhang, G.B., 2011a. Petrology and SHRIMP $\mathrm{U}-\mathrm{Pb}$ dating of Xitieshan eclogite, North Qaidam UHP metamorphic belt, NW China. Journal of Asian Earth Sciences 42, 752-767.

Zhang, C., van Roermund, H., Zhang, L., Spiers, C., 2012. A polyphase metamorphic evolution for the Xitieshan paragneiss of the north Qaidam UHP metamorphic belt, western China: in-situ EMP monazite and U-Pb zircon SHRIMP dating. Lithos 136-139, 27-45.

Zhang, C., Bader, T., Zhang, L., van Roermund, H., 2015. The multi-stage tectonic evolution of the Xitieshan terrane, North Qaidamorogen,western China: From Grenville-age orogeny to early-Paleozoic ultrahigh pressure metamorphism, Gondwana Research http://dx.doi.org/10.1016/j.gr.2015.04.011.

Zhang, G.B., Song, S.G., Zhang, L.F., Niu, Y.L., 2008. The subducted oceanic crust within continental-type UHP metamorphic belt in the North Qaidam, NW China: evidence from petrology, geochemistry and geochronology. Lithos 104, 99-118.

Zhang, G.B., Zhang, L.F, Song, S.G., 2009a. UHP metamorphic evolution and SHRIMP 
geochronology of a meta-ophiolitic gabbro in the North Qaidam, NW China. Journal of Asian Earth Sciences 35, 310-322.

Zhang, G.B., Ellis, D.J., Christy, A.G., Zhang, L.F., Niu, Y.L., Song, S.G., 2009b. UHP metamorphic evolution of coesite-bearing eclogite from the Yuka terrane, North Qaidam UHPM belt, NW China. European Journal of Mineralogy 21, 1287-1300.

Zhang, G.B., Zhang, L.F., Christy, A.G., 2013. From oceanic subduction to continental collision: An overview of HP-UHP metamorphic rocks in the North Qaidam UHP belt, NW China. Journal of Asian Earth Sciences 63, 98-111.

Zhang, G.B., Zhang, L.F., Chrisity, A., Song S.G., Li, Q.L., 2014. Differential exhumation and cooling history of North Qaidam UHP metamorphic rocks, NW China: Constraints from zircon and rutile thermometry and $\mathrm{U}-\mathrm{Pb}$ geochronology. Lithos 205, 15-27.

Zhang, G.B., Niu, Y.L., Song, S.G., Zhang, L.F., Tian, Z.L., Christy, A.G., Han, L., 2015. Trace element behavior and $\mathrm{P}-\mathrm{T}-\mathrm{t}$ evolution during partial melting of exhumed eclogite in the North Qaidam UHPM belt (NW China): Implications for adakite genesis. Lithos 226, 65-80.

Zhang, J.X., Xu, Z.Q., Chen, W., Xu, H. F., 1997. A tentative discussion on the ages of the subduction-accretionary complex/volcanic arcs in the middle sector of North Qilian Mountains. Acta Petrologica et Mineralogica 16, 112-119 (in Chinese with English abstract).

Zhang, J.X., Xu, Z.Q., Xu, H.F., Li, H.B., 1998. Framework of North Qilian Caledonian Subduction-Accretionary wedge and its deformation dynamics. Scientia Geologica Sinica 33, 290-299 (in Chinese with English abstract).

Zhang, J.X., Zhang, Z.M., Xu, Z.Q., Yang, J.S., Cui, J.W., 2000. Discovery of khondalite series from the western segment of Altyn and their petrological and geochronological studies. Science in China (Series D) 43, 308-31.

Zhang, J.X., Zhang, Z.M., Xu, Z.Q., Yang, J.S., Cui, J.W., 2001a. Petrology and geochronology of eclogites from the western segment of the Altyn Tagh, northwestern China. Lithos 56, 189-208.

Zhang, J.X., Wan, Y.S., Xu, Z.Q., Yang, J.S., Cui, J.M., 2001b. Discovery of basic rock and its formation age in Delingha area, north Qaidam Mountains. Acta Petrologica Sinica 17, 453-458 (in Chinese with English abstract).

Zhang, J.X., Meng, F.C., Yang J.S., 2004. Eclogitic metapelites in the western segment of the north Qaidam Mountains: Evidence on "in situ" relationship between eclogite and its country 
rock. Science in China Ser. D Earth Sciences 47, 1102-1112.

Zhang, J.X., Yang, J.S., Mattinson, C.G., Xu, Z.Q., Meng, F.C., Shi, R.D., 2005a. Two contrasting eclogite cooling histories, North Qaidam HP/UHP terrane, western China: petrological and isotopic constraints. Lithos 84, 51-76.

Zhang, J.X., Meng, F.C., Yang, J.S. 2005b. A new HP/LT metamorphic terrane in the northern Altyn Tagh, western China. International Geology Review 47, 371-386.

Zhang, J.X., Mattinson, C.G., Meng, F.C., Wan, Y.S. 2005c. An early Paleozoic HP/HT granulite - garnet peridotite association in the south Altyn Tagh, NW China: $P-T$ history and $\mathrm{U}-\mathrm{Pb}$ geochronology. Journal of Metamorphic Geology 23, 491-510.

Zhang, J.X., Meng, F.C., 2006. Lawsonite-bearing eclogites in the north Qilian and north Altyn Tagh: evidence for cold subduction of oceanic crust. Chinese Science Bulletin, 51, 1238-1244.

Zhang, J.X., Meng, F.C., Yu, S.Y., Chen, W., Chen, S.Y., 2007a. Ar-Ar geochronology of blueschist and eclogite in the north Altyn Tagh HP/LT metamorphic belt and their regional tectonic implication. Geology in China 34, 558-564 (in Chinese with English abstract).

Zhang, J.X., Meng, F.C., Wan, Y.S., 2007b. A cold Early Paleozoic subduction zone in the North Qilian Mountains, NW China: petrological and U-Pb geochronological constraints. Journal of Metamorphic Geology 25, 285-304.

Zhang, J.X., Meng, F.C., Yu, S.Y., Qi, X.X., 2007c. Metamorphic history recorded in high pressure mafic granulites in Luliangshan, North Qaidam Mountains: Evidence from petrology. Earth Science Frontiers 14, 85-97.

Zhang, J.X., Mattinson, C.G., Meng, F.C., Wan, Y.S., Tung, K., 2008. Polyphase tectonothermal history recorded in granulitized gneisses from the North Qaidam HP/UHP metamorphic terrane, Western China: evidence from zircon U-Pb geochronology. Geological Society of America Bulletin 120, 732-749.

Zhang, J.X., Mattinson, C.G., Meng, F,C., Yang H,J., Wan, Y.S., 2009a. U-Pb geochronology of paragneisses and metabasite in the Xitieshan area, north Qaidam Mountains, western China: constraints on the exhumation of HP/UHP metamorphic rocks. Journal of Asian Earth Sciences 35, 245-258.

Zhang, J.X., Meng, F.C., Li, J.P., Mattinson, C.G., 2009b. Coesite in eclogite from the north Qaidam Mountains and its implication. Chinese Science Bulletin, 54, 1105-1110. 
Zhang, J.X., Yu, S.Y., Meng, F.C., Li, J.P., 2009c. Paried high-pressure granulite and eclogite in collision orogens and their geodynamic implications. Acta Petrologica Sinica 25, 2050-2066 (in Chinese with English abstract).

Zhang, J.X., Mattinson, C.G., Yu, S.Y., Li, J.P., Meng, F.C., 2010. U-Pb zircon dating of coesite-bearing eclogites from the southern Dulan area of the North Qadiam HP/UHP terrane, northwestern China: New constraints on ages of UHP metamorphism and protoliths, Journal of Metamorphic Geology 28: 955-978.

Zhang, J.X., Li, H.K., Meng, F.C., Xiang, Z.Q., Yu, S.R., Li, J.P., 2011. Polyphase tectonothermal events recorded in "metamorphic basement" from the Altyn Tagh, the southeastern margin of Tarim basin, Western China: constraint fromU-Pb zircon geochronology. Acta Petrologica Sinica 27, 23-46 (in Chinese with English abstract).

Zhang, J.X., Li, J.P., Yu, S.Y., Meng, F.C., Mattinson, C.G., Yang, H.J., Ker, C.M., 2012. Provenance of eclogitic metasediments in the north Qilian HP/LT metamorphic terrane, western China: geodynamic implications for early Paleozoic subduction-erosion. Tectonophysics 570-571, 78-101.

Zhang, J.X., Mattinson, C.G., Yu, S.Y., Li, Y.S., 2014. Combined rutile-zircon thermometry and U-Pb geochronology: new constraints on Early Paleozoic HP/UHT granulite in the south Altyn Tagh, north Tibet, China. Lithos 200-201, 241-257.

Zhang, Q., Sun, X.M., Zhou, D.J., Qian, Q., Chen, Y., Wang, Y.M., Jia, X.Q., Han, S., 1997. The characteristics of northern Qilian ophiolites, formation settings and their tectonic significance. Advance in Earth Science 12, 366-393 (in Chinese with English abstract).

Zhang, Z.M., Dong, X., Santosh, M., Zhao, G.C., 2014. Metamorphism and tectonic evolution of the Lhasa terrane, Central Tibet. Gondwana Research 25, 170-189. 


\section{Figure captions}

Fig. 1 Geological sketch map of the Altun-Qilian-Kunlun (AQK) orogenic system in the northern Tibet. References signed by number are listed in Table 2.

Fig. 2 (A) Simplified geological map showing major litho-tectonic units in the north Altun (NAT) (modified after Zhang et al., 2005a). (B) Local structure map of HP/LT metamorphic slab.

Fig. 3 Field pictures showing relationship between eclogite, blueschist and metasedimentary rock in the NAT. Ecl=eclogite, BS=blueschist, QS=quartz mica schist, $\mathrm{CaS}=$ calcareous schist.

Fig. 4 Microtextures of the NAT HP/LT metamorphic rocks. (a) Garnet porphyroblast in eclogite contains oriented inclusions of omphacite, extending to matrix defined well-developed foliations (BSE image); (b) Garnet porphyroblast in blueschist is surrounded oriented glaucophane and barroisite. Epidote porphyroblasts cross-cut the foliation defined mainly by glaucophane (BSE image); (c) Garnet porphyroblast in mica schist is surrounded by oriented phengite and quartz, and phengite is replaced locally by chlorite (plane polarized light, PPL); (d) Oriented chloritoid defines a foliation in Cld-bearing mica schist (PPL).

Fig. 5 Simplified geological map showing major litho-tectonic units in the north Qilian Mountains (modified after Zhang et al., 2007b)

Fig. 6 Field pictures showing relationship between eclogites, blueschists and metasedimentary rocks in the NQL. (a) Block of eclogitic rocks (Ecl) in mica schist (MS); (b and c) eclogite (Ecl) interlayered with blueschist (BS); (d) small eclogite pod (Ecl) within mica schist (MS).

Fig. 7 Microtextures of the NQL HP/LT metamorphic rocks (PPL). (a) Sub-idioblastic 
garnet is surrounded by oriented omphacite, phengite and zoisite (eclogite); (b) Idioblastic garnet is surrounded by omphacite and glaucophane (eclogitic metabasite); (c) Sub-idioblastic garnet is surrounded by oriented glaucophane (blueschist); (d) Oriented omphacite and glaucophane define a foliation, and omphacite and glaucophane have straight boundaries (Omp-bearing micaschists); (e) Chloritoid and garnet porphyroblasts are surrounded by oriented glaucophane, phengite and quartz (chloritoid-bearing mica schist); (f) Oriented piemontite defines a foliation (metachert).

Fig. 8 P-T path for the eclogites, garnet peridotites and HP granulites in different UHP metamorphic units along the NQD-SAT. Reference sources: 1-Zhang J et al. (2005a) and Zhang G et al. (2009a); 2-Song et al.(2003), Zhang G. et al. (2009b) and Zhang J. (2010); 3-Zhang J et al. (2005) and Zhang C. et al. (2011); 4-Yang and Powell (2008); 5-Song et al. (2005); 6-Song et al. (2003) and Yu et al. (2011); 7-Liu et al. (2002); 8-Zhang et al. (2005b); 9-Zhang et al. (2001) and Liu et al. (2012). The petrogenetic P-T grid is modified from Liou et al. (1998). Metamorphic-facies abbreviations: $\mathrm{AM}=$ amphibolite; $\mathrm{Amp}-\mathrm{EC}=$ amphibolite-eclogite; $\mathrm{BS}=$ blueschist; $\mathrm{EA}=$ epidote amphibolite; $\mathrm{EC}=$ eclogite $; \mathrm{Ep}-\mathrm{EC}=$ epidote-eclogite; $\mathrm{GR}=$ granulite; GS = greenschist $;$ HGR = high pressure granulite Lw-EC $=$ lawsonite-eclogite.

Fig. 9 Microtextures of HP granulite at Luliangshan, NQD. (a) Garnet porphyroblast is surrounded by amphibole and symplectite of clinopyroxene + plagioclase (PPL); (b) Clinopyroxene + plagioclase symplectite shows a pseudomorph after earlier omphacite (?) (crossed polarized light, CPL); (c) Orthopyroxene + amphibole + plagioclase corona occurs between garnet and orthopyroxene + plagioclase symplectite (PPL); (d) Omphacite occurs as inclusion in Garnet porphyroblast (BSE image).

Fig. 10 Field picture and photomicrographs of HP granulite at Aercituoshan of the south Dulan area, NQD. (a) Migmatite consists of mafic granulite (melanosome) and felsic granulite (leucosome); (b) and (c) Garnet + clinopyroxene + kyanite + 
plagioclase assemblage in HP mafic granulite (b: PPL; c: CPL); (d) Oriented kyanite, feldspar and quartz define the foliation in HP felsic granulite (leucosome) (CPL).

Fig. 11 Field pictures and photomicrographs of HP granulite at Bashiwake, SAT. (a) and (b): Mafic granulites occur as lenses within felsic granulites; (c) Garnet + kyanite + perthite (former ternary feldspar) + quartz assemblage in felsic granulite (CPL); (d) Garnet + clinopyroxene + plagioclase + quartz + rutile assemblage in mafic granulite (PPL); (e) Spinel grows between kyanite and garnet in felsic granulite (PPL); (f) Sapphrine + plagioclase symplectite in mafic granulite (PPL).

Fig. 12 Geological map showing sample locations of low-medium pressure mafic granulite and migmatitic metapelites at the Tula area, SAT.

Fig.13 Field picture and photomicrographs showing the low-medium pressure granulite-facies assemblage and associated anatexis in the Tula area, SAT. (a) Field picture showing the migmatitic texture of metapelite; (b) Oriented sillimanite define the foliation in migmatitic metapelite (PPL); (c) and (d) Highly arcuate K-feldspar grains envelop the quartz grains, and veinlet-like K-feldspar intrude into garnet, reflecting pseudomorphs of former melts (c: PPL; d: CPL); (e) and (f) Orthopyroxene + clinopyroxene + amphibole + plagioclase assemblage in mafic granulite (e: PPL; f: $\mathrm{CPL}) ;(\mathrm{g})$ and $(\mathrm{h})$ Garnet + orthopyroxene + clinopyroxene +amphibole + plagioclase assemblage in mafic granulite (g: PPL; h: BSE image).

Fig. 14 Zircon $\mathrm{U}-\mathrm{Pb}$ concordia diagrams for mafic granulite and migmatitic metapelite in the Tula area.

Fig. 15 Microtextures of migmatitic metapelites at Luliangshan and Xitieshan, NQD (PPL). (a) and (b) Garnet, sillimanite, biotite, feldspar and quartz assemblage in Luliangshan paragneisses. (b) Kyanite (or pseudomorph) is rimmed by sillimanite; (c) garnet and kyanite porphyroblasts in Xitieshan paragneiss. (d) garnet, sillimanite, 
1586 biotite, feldspar and quartz assemblage in Xitieshan paragneiss. Sillimanite and 1587 biotite define the foliation.

1588

1589 Fig. 16 Geological sketch map showing dating data of various early Paleozoic 1590 metamorphic rocks in the AQK orogenic system, northern Tibet. References signed by 1591 number are listed in Table 2.

1592

1593 Fig. 17 Model showing geodynamic setting of formation for HP granulites and 1594 associated eclogites. 


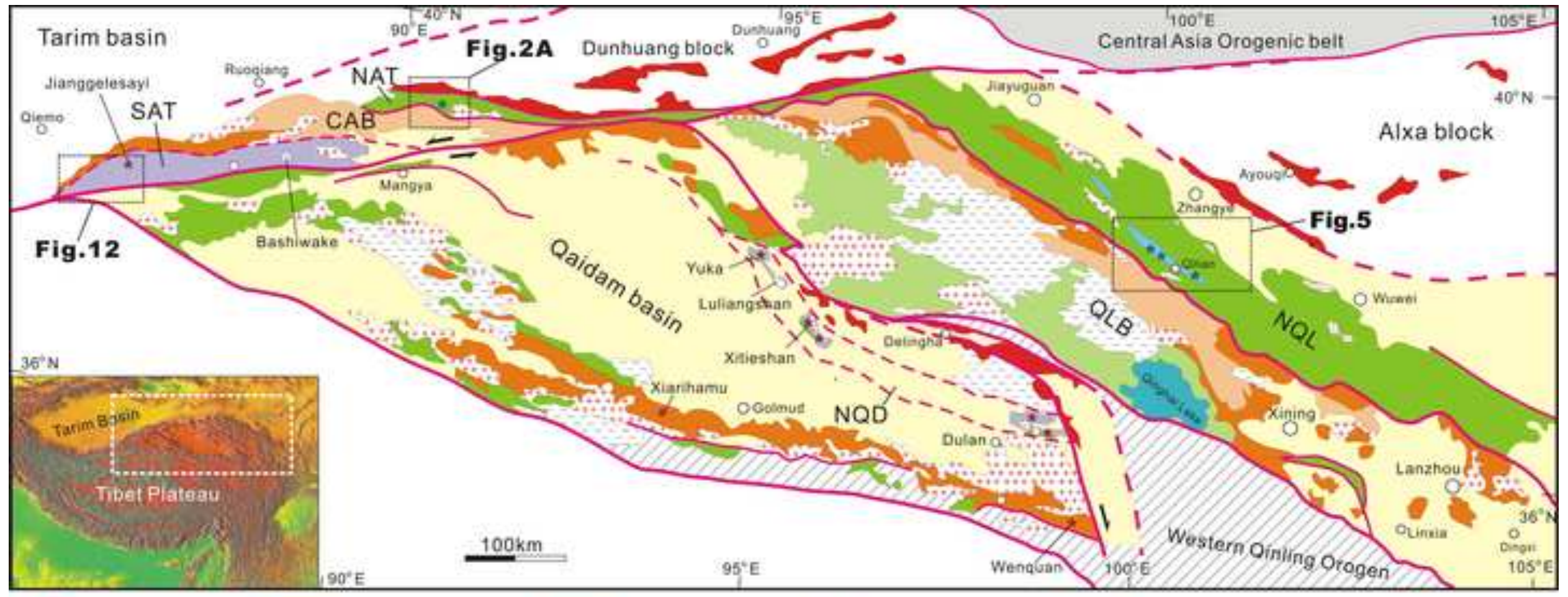

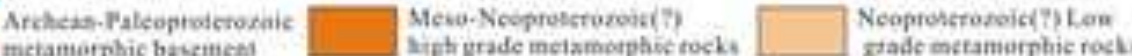

Farly Palcoxoic subduction-

Farly Paleonaic

Fase Palowoic-Mesoxoic

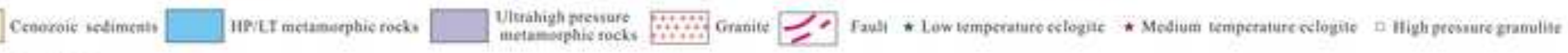
Gamea peridoua-

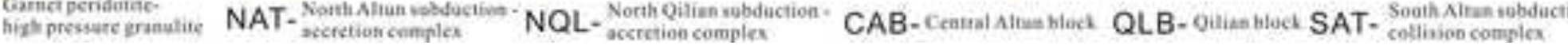
NQD. North Quidam subdection - 
Figure 2
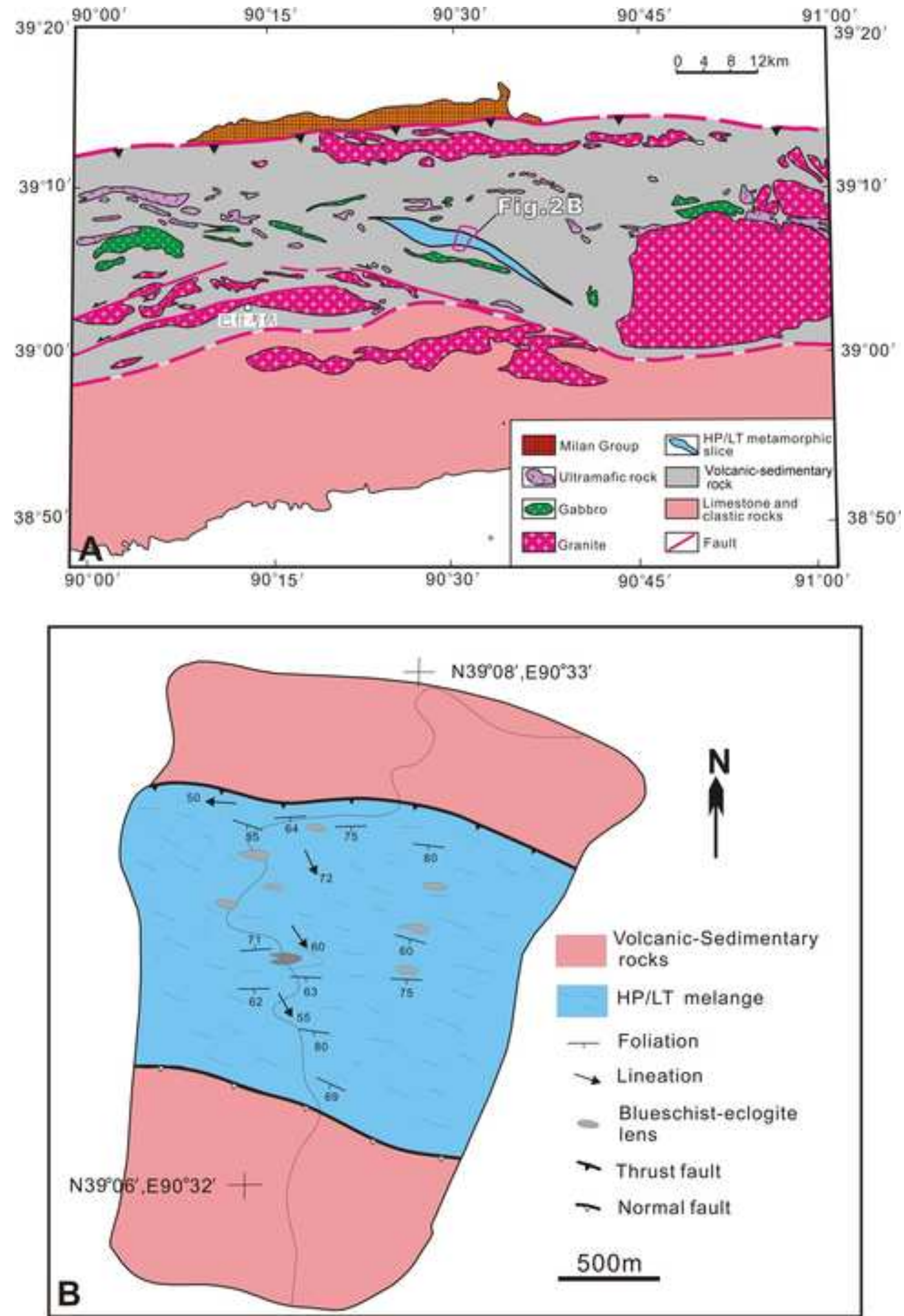

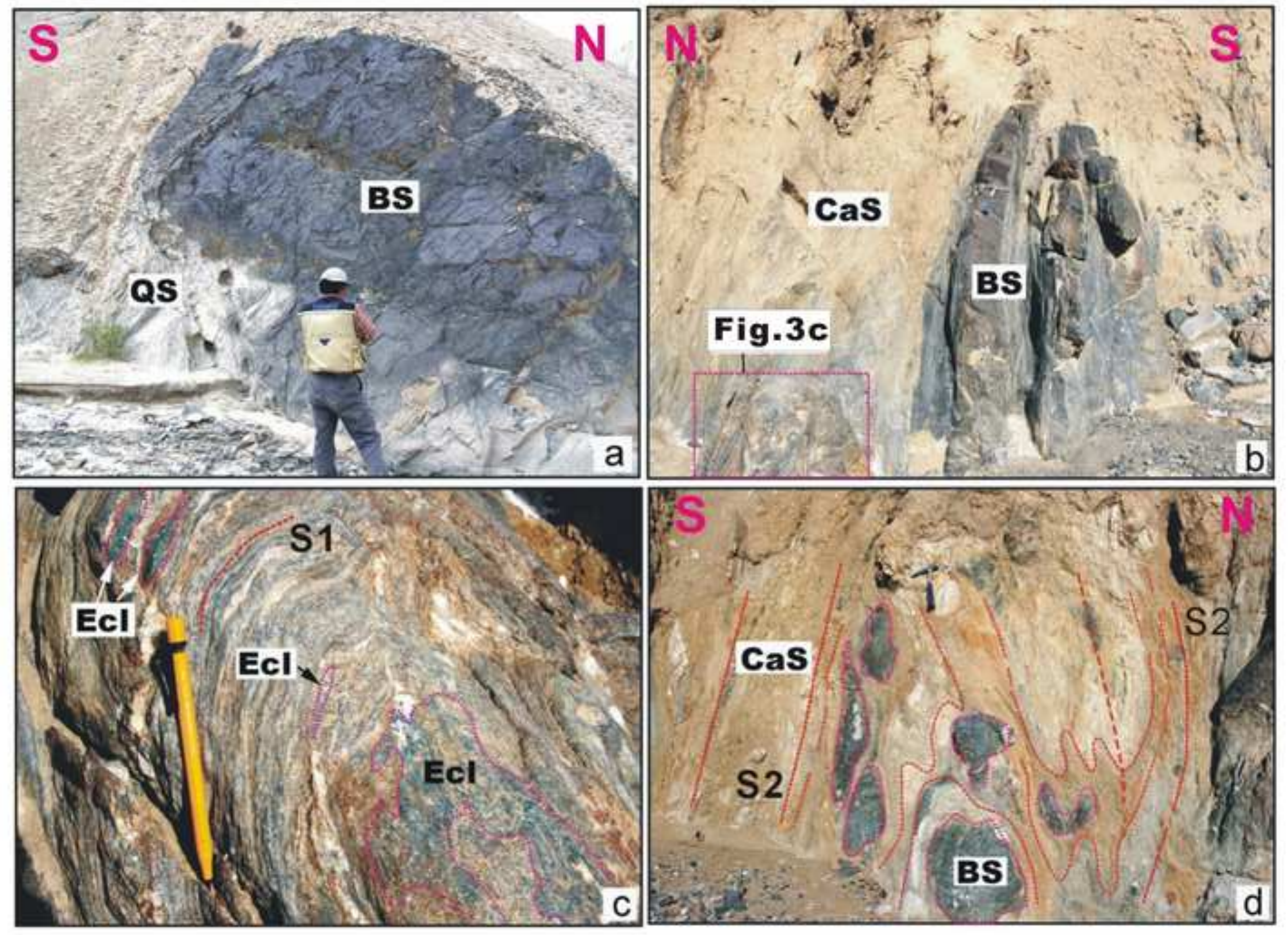

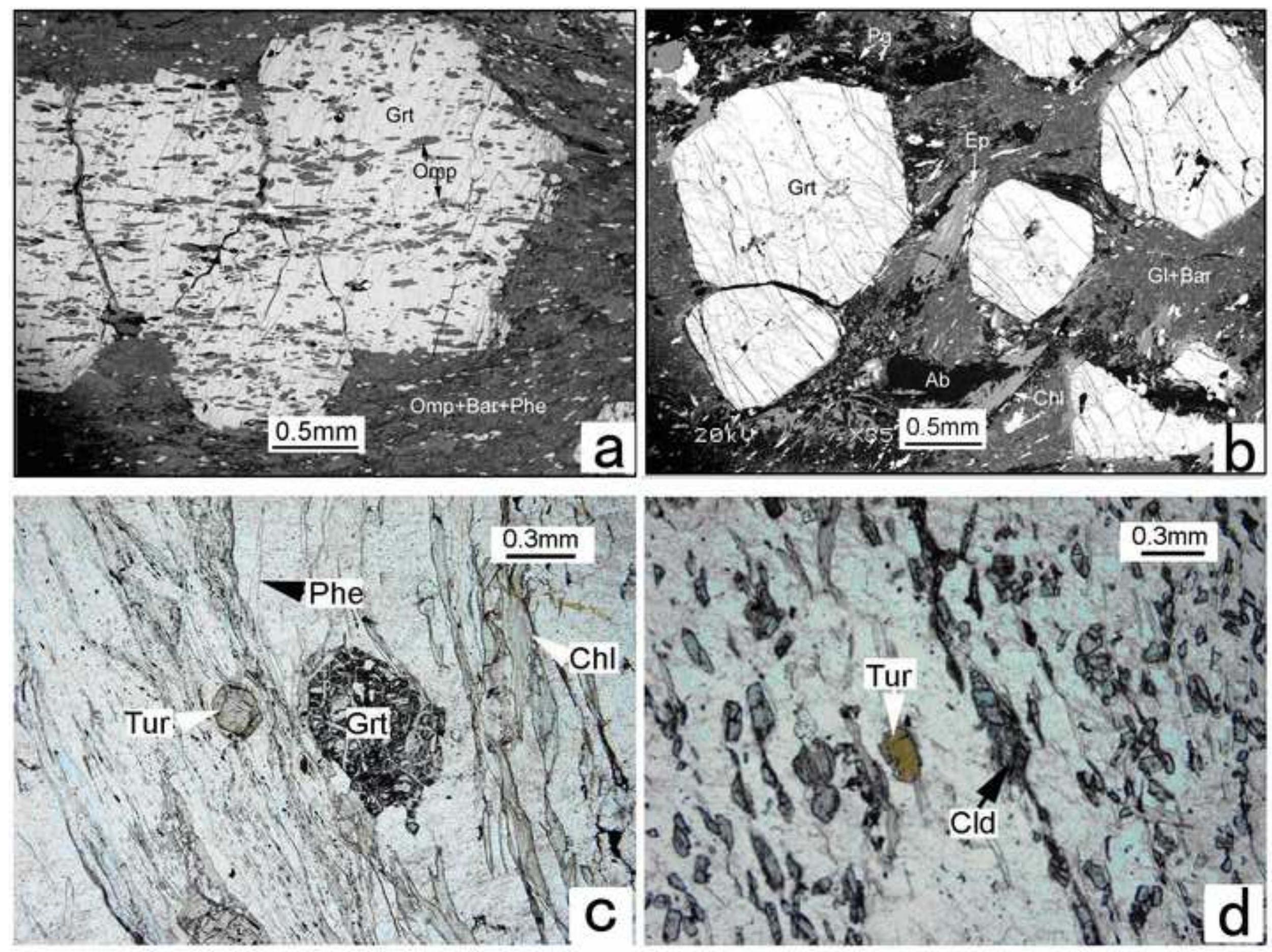


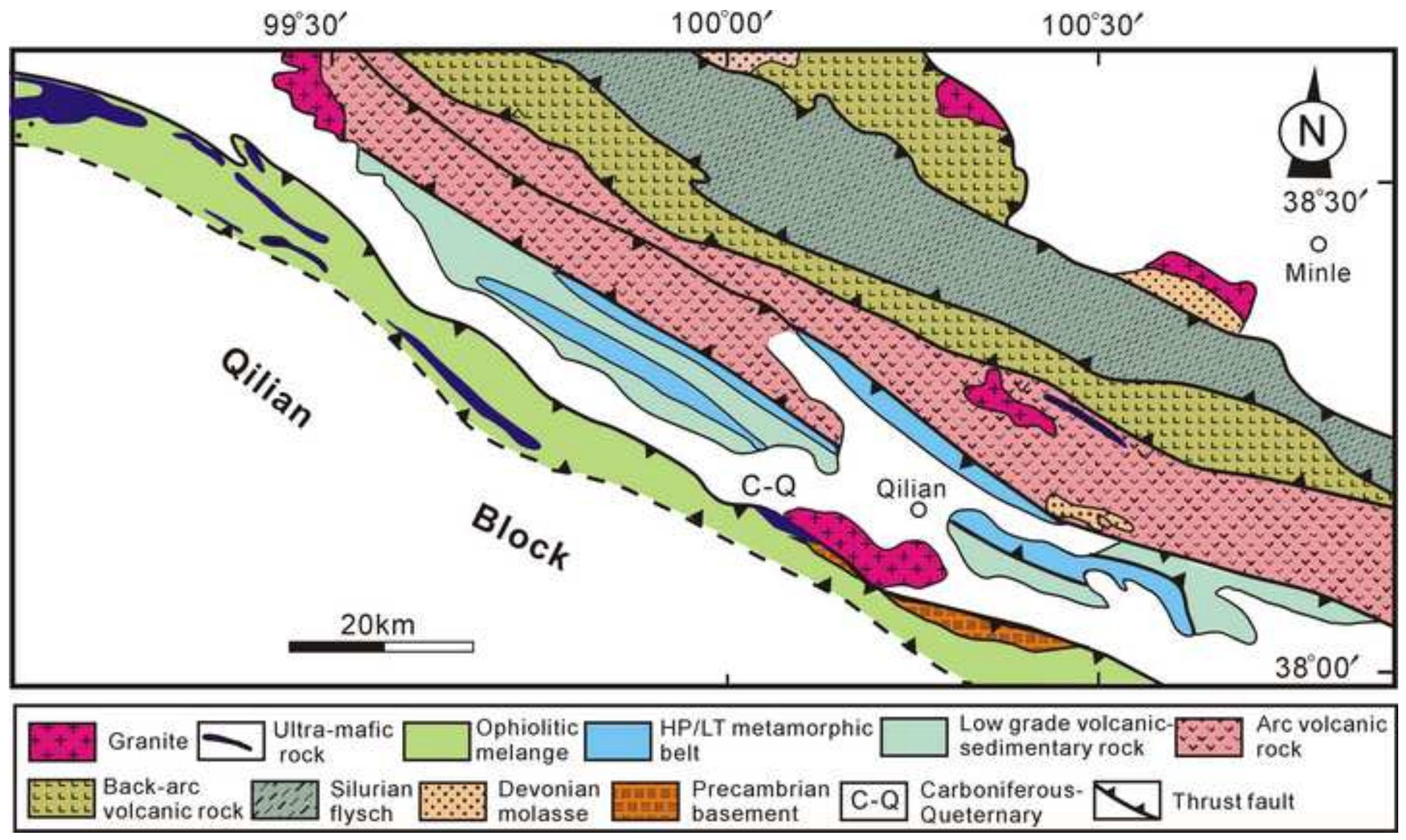



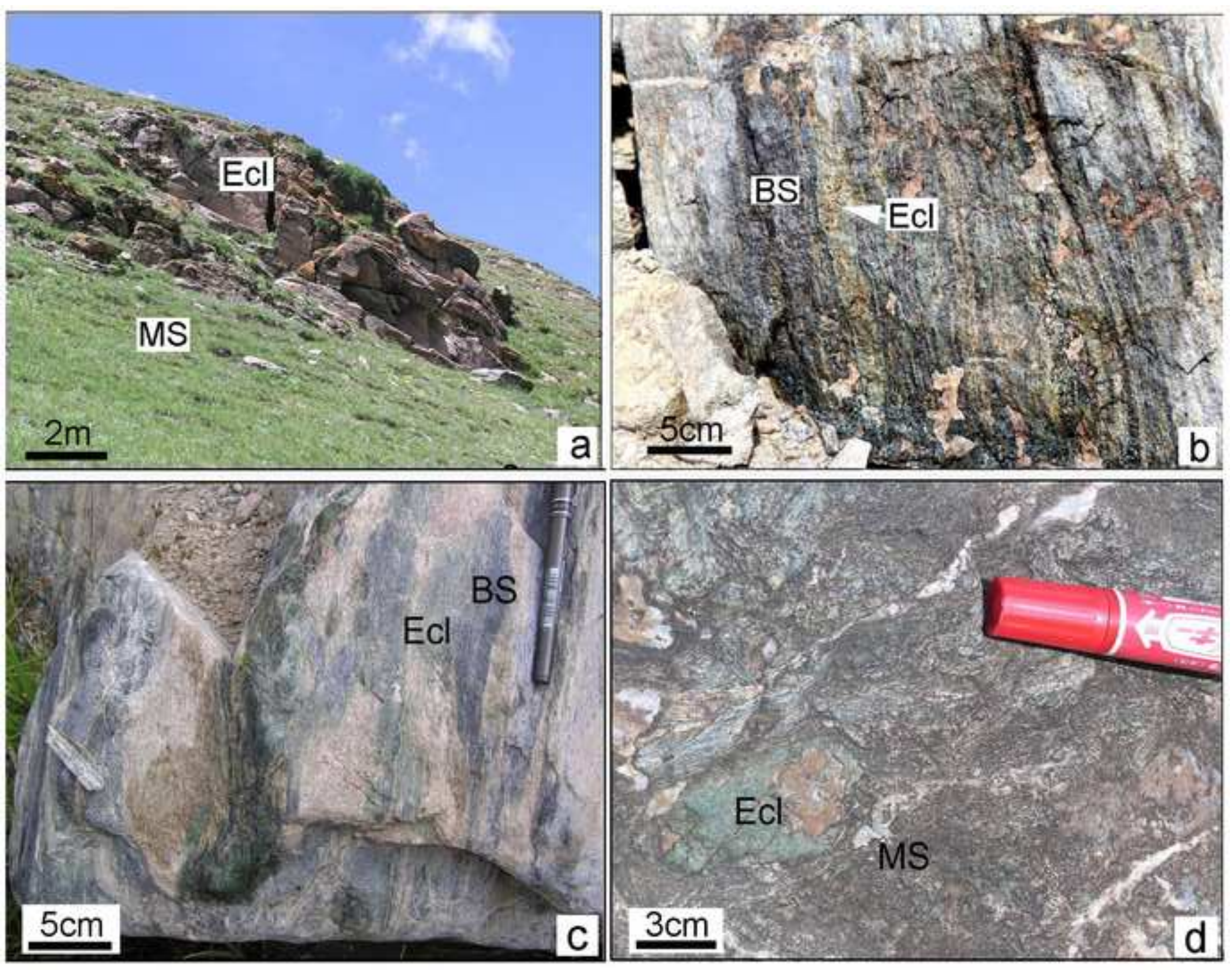

$\mathrm{ECl}$

MS

$3 \mathrm{~cm}$

2. $3 \log ^{2}$ 

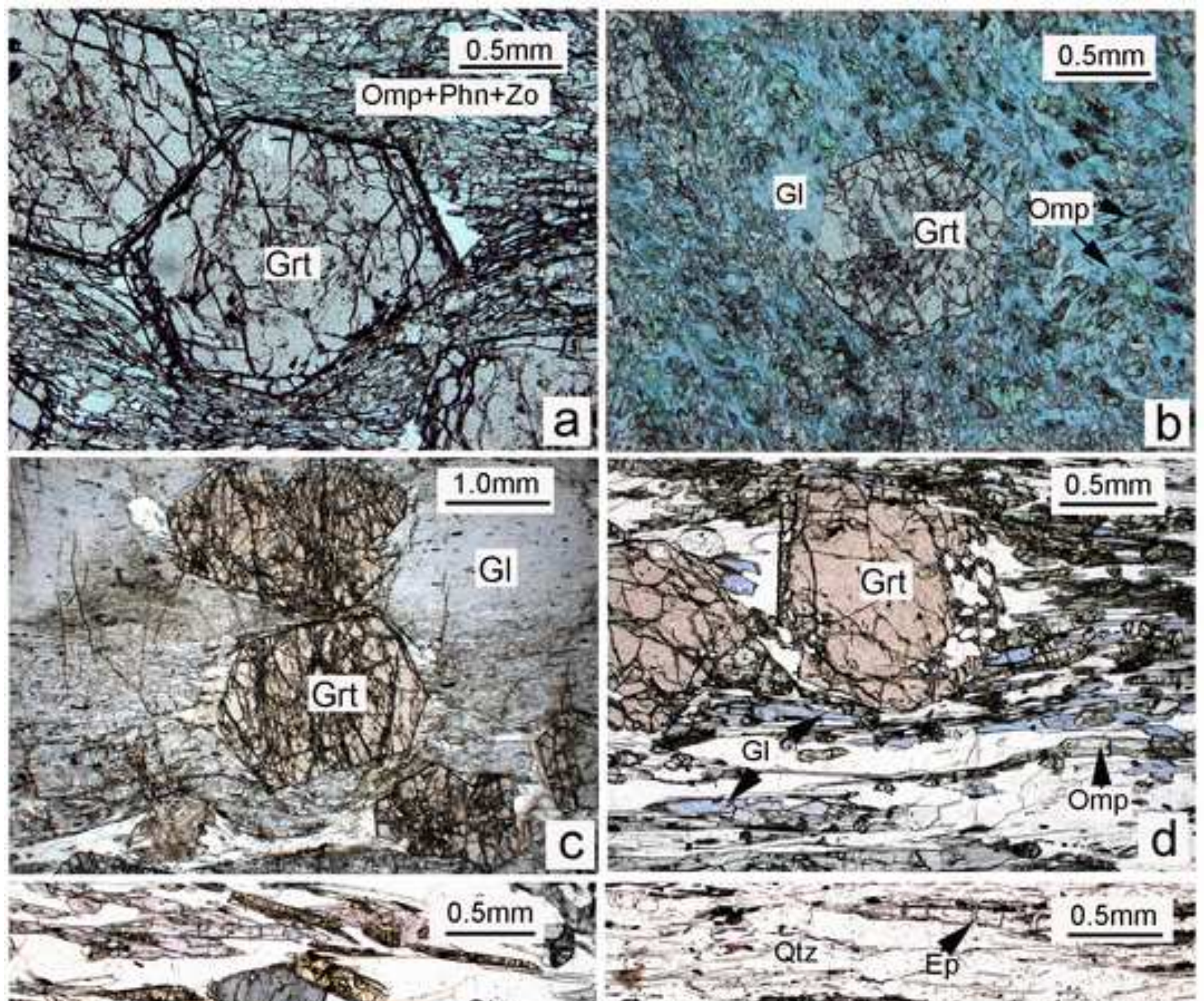

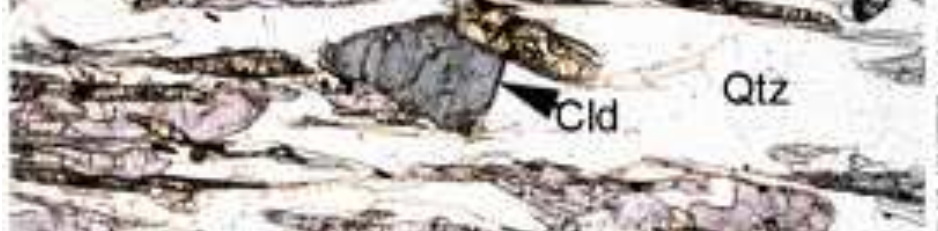
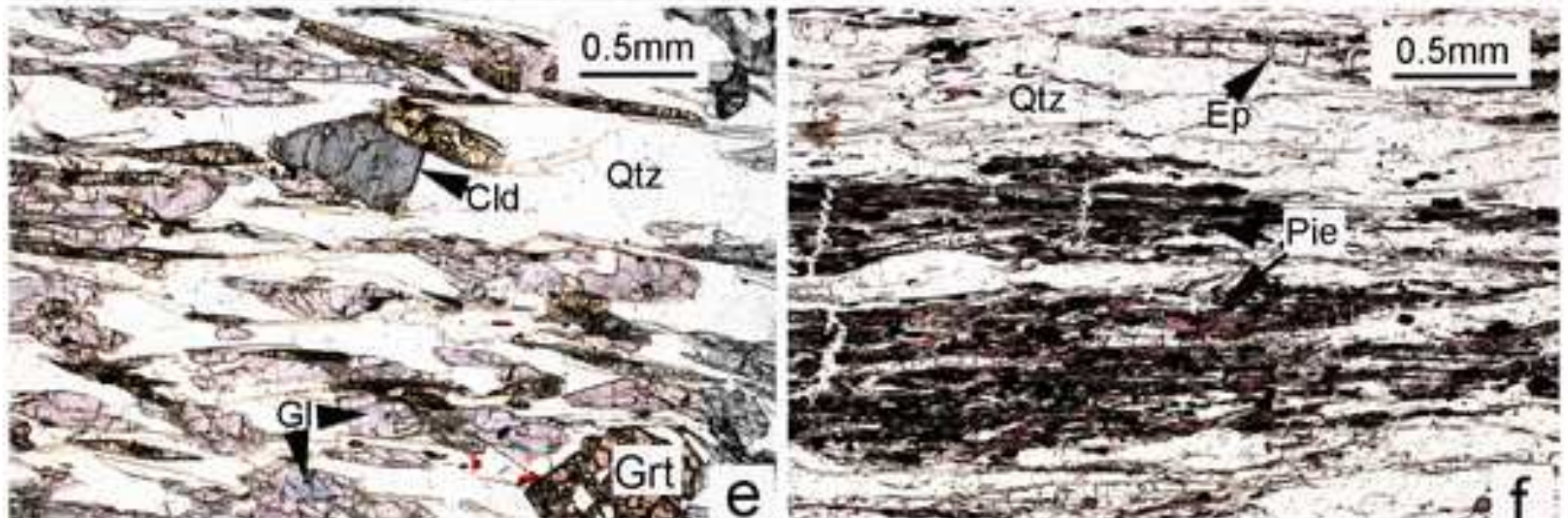
13 Qtz EP

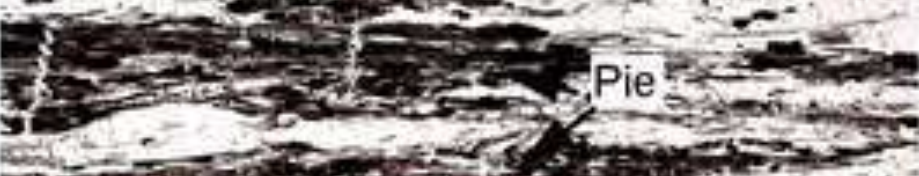
(1)

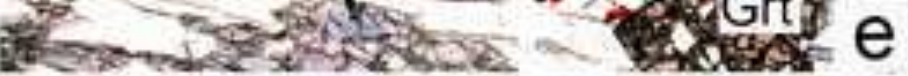




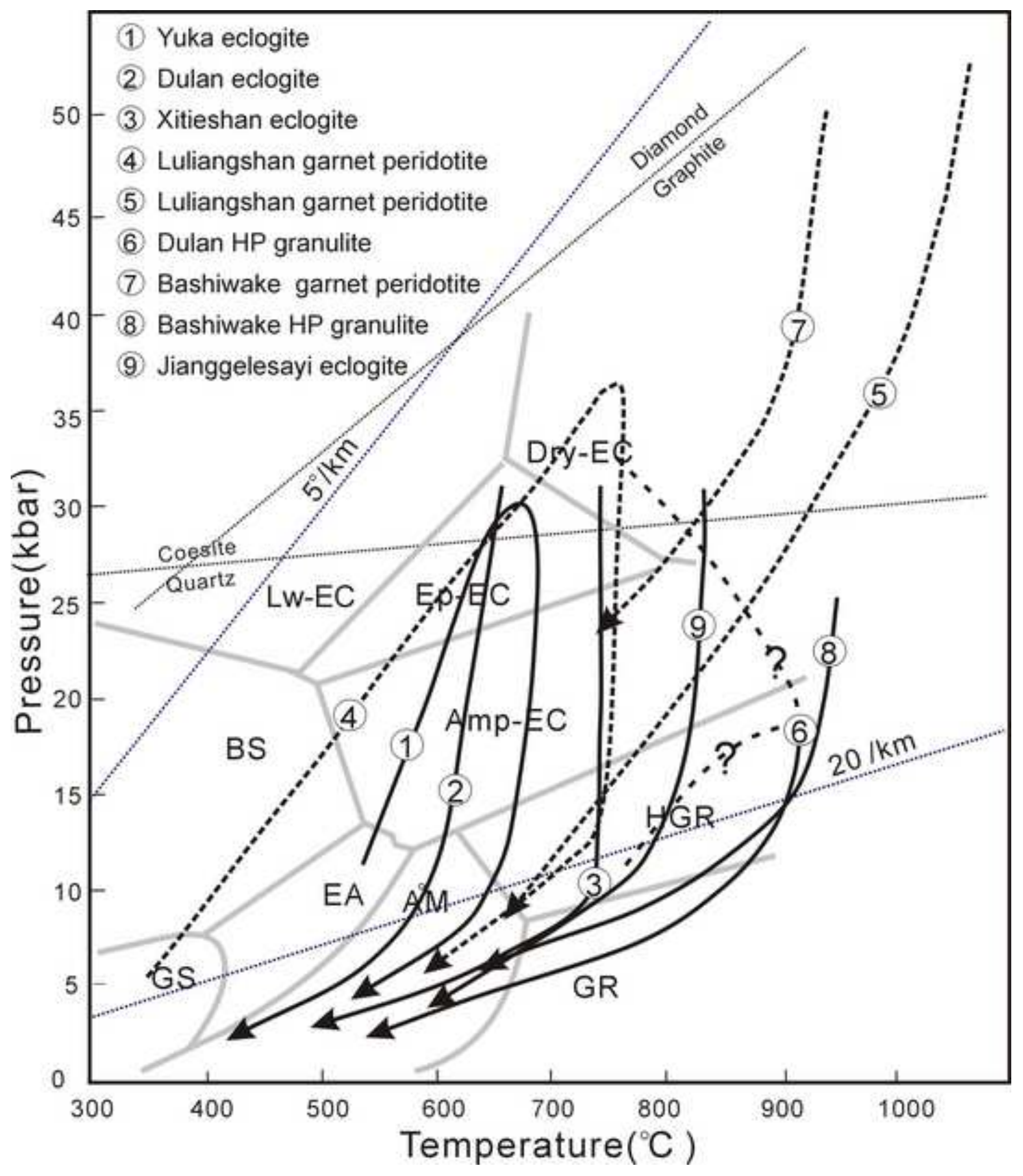



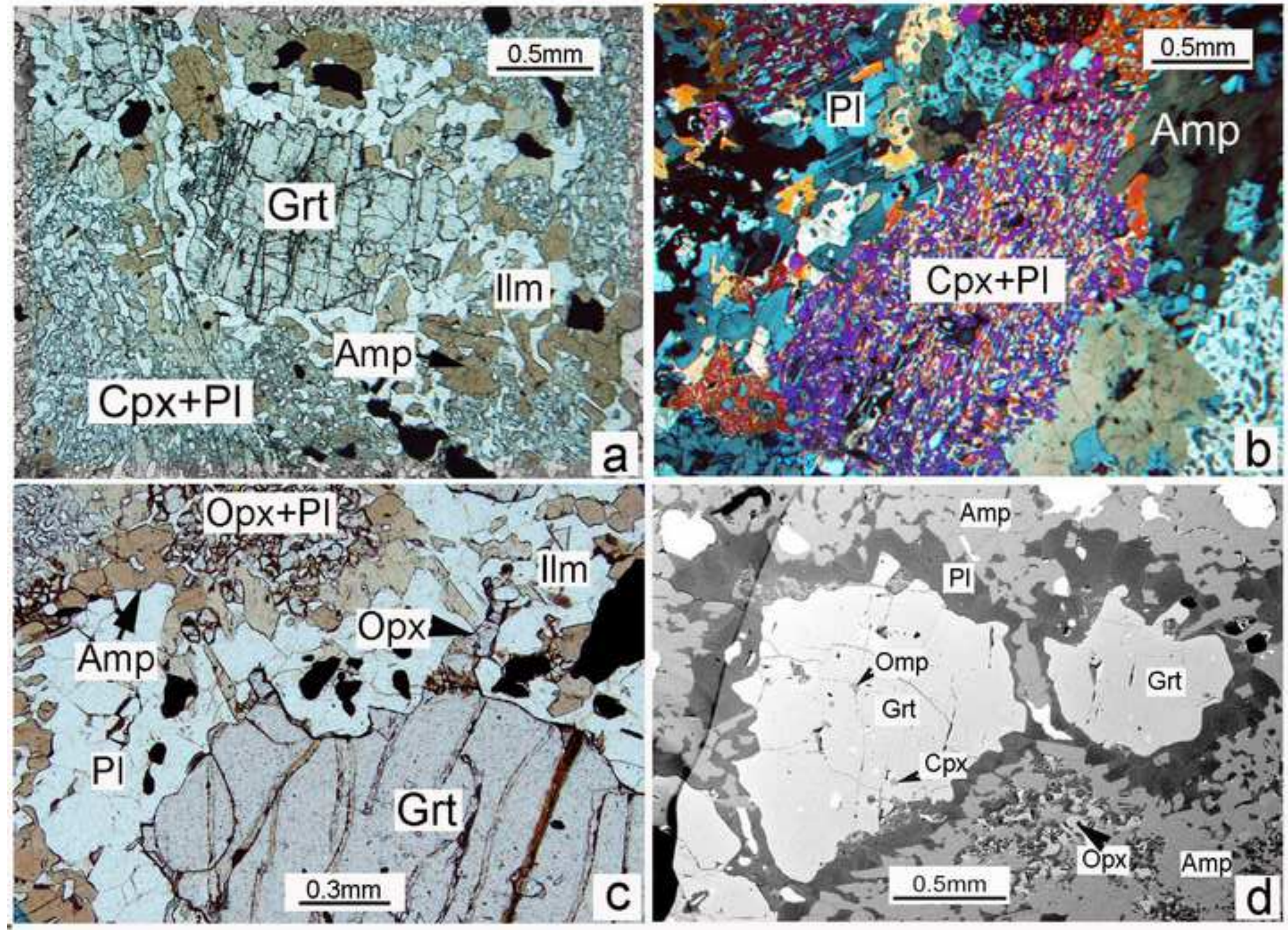

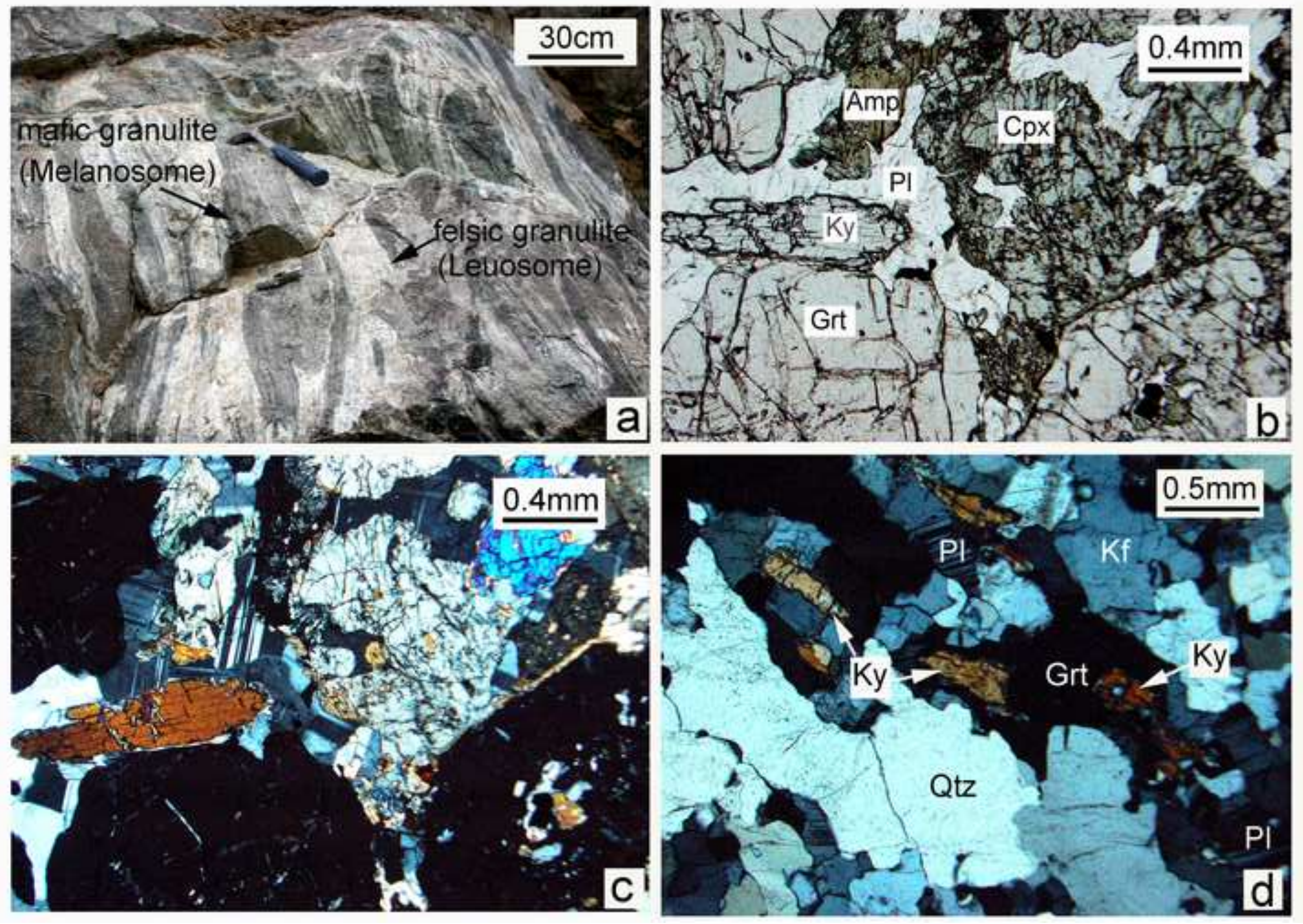

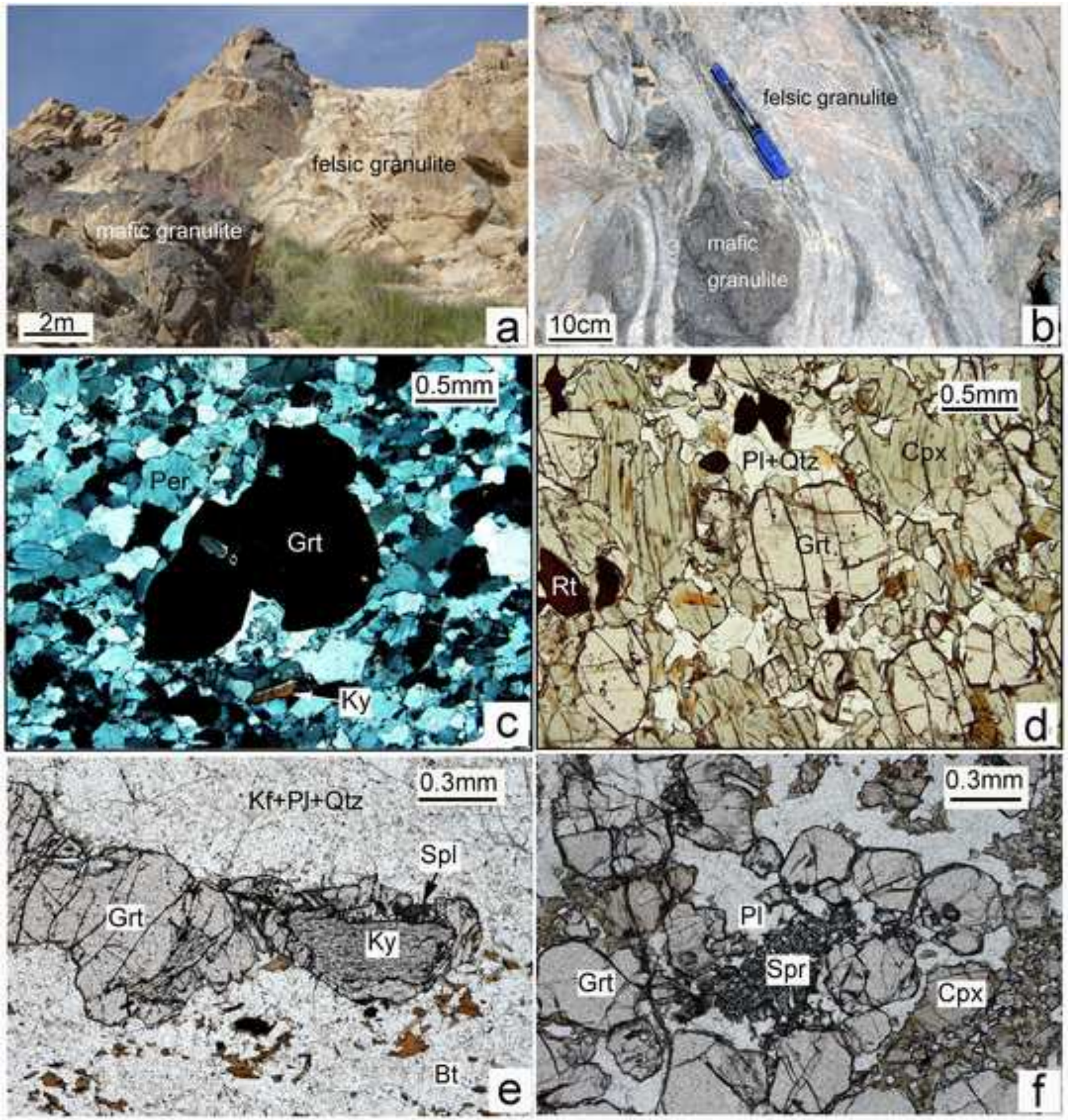


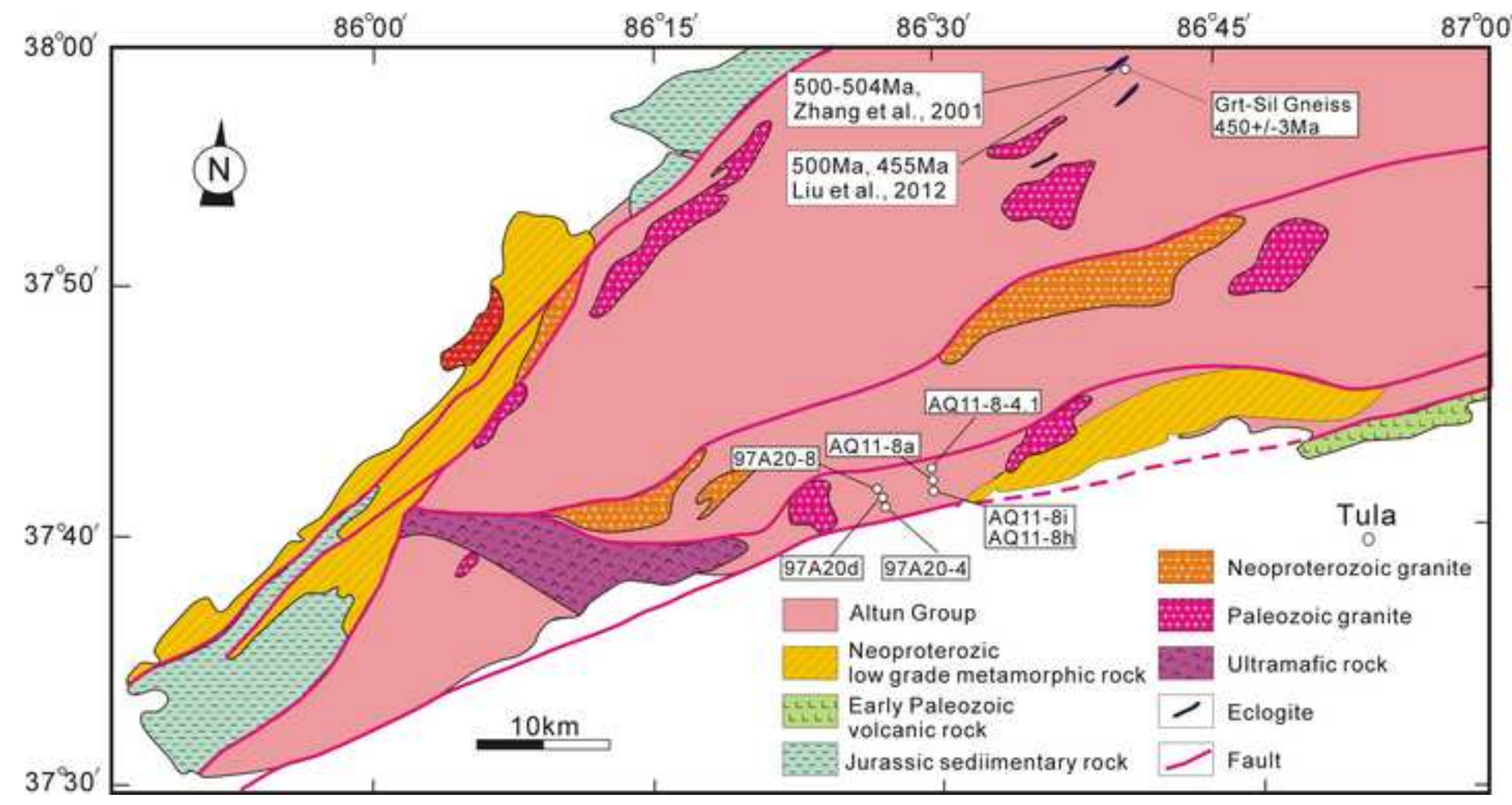



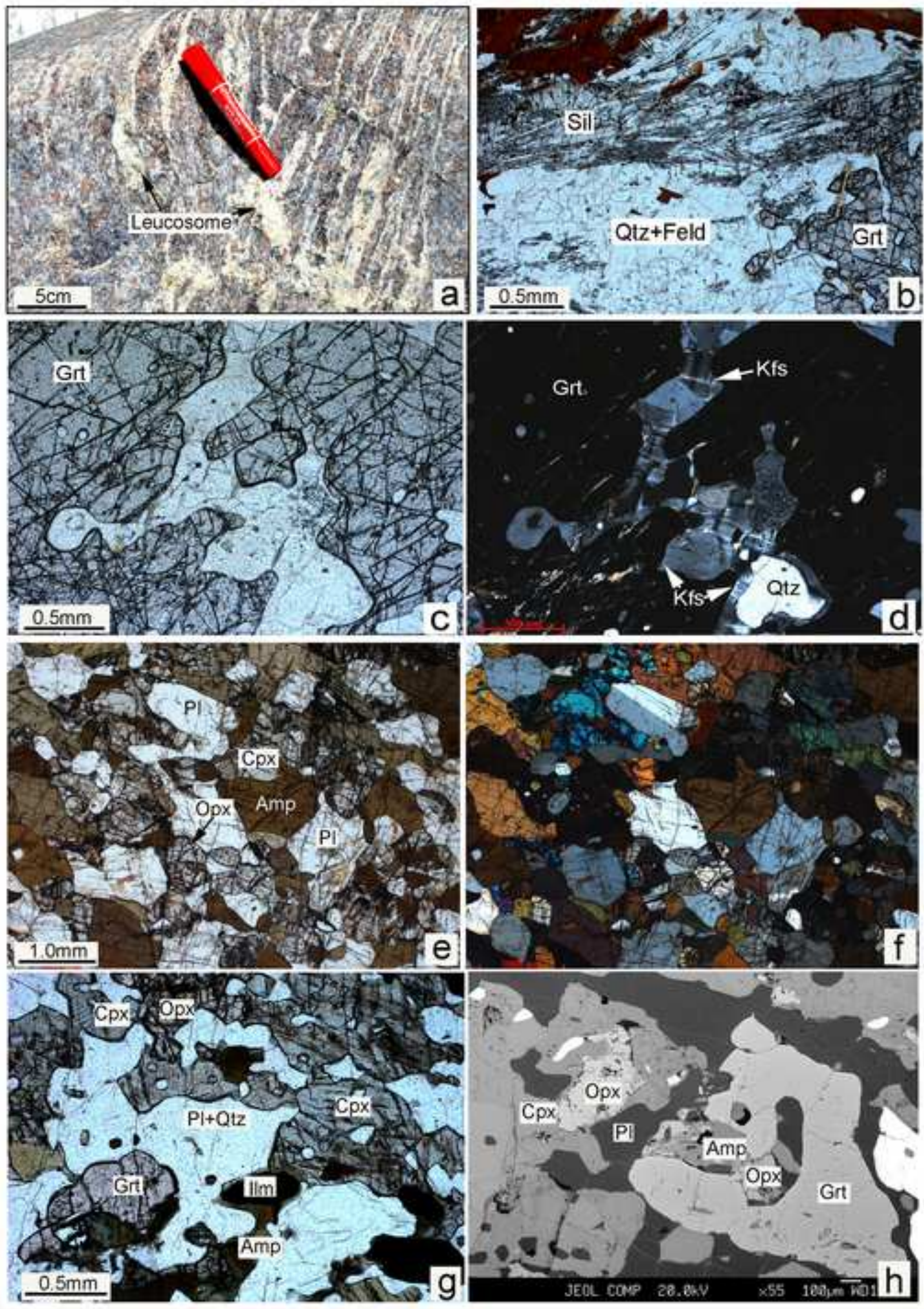

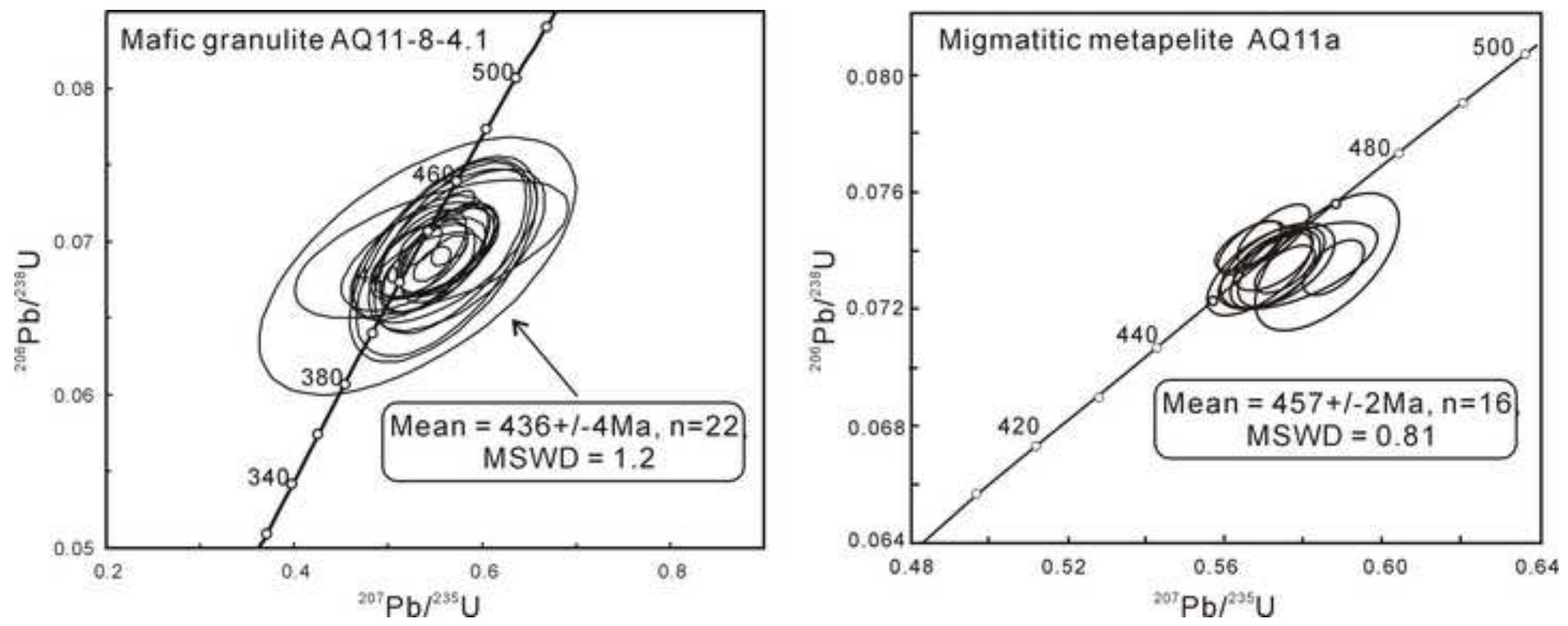


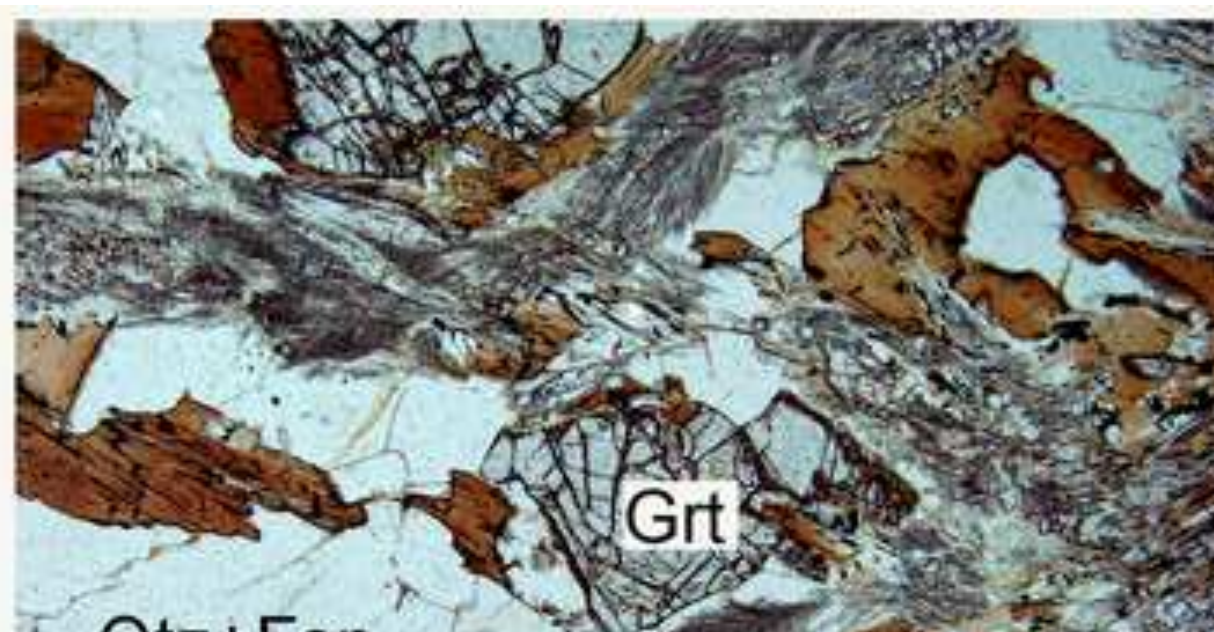

$\mathrm{Qtz}+\mathrm{Fsp}$ ist Sil a da

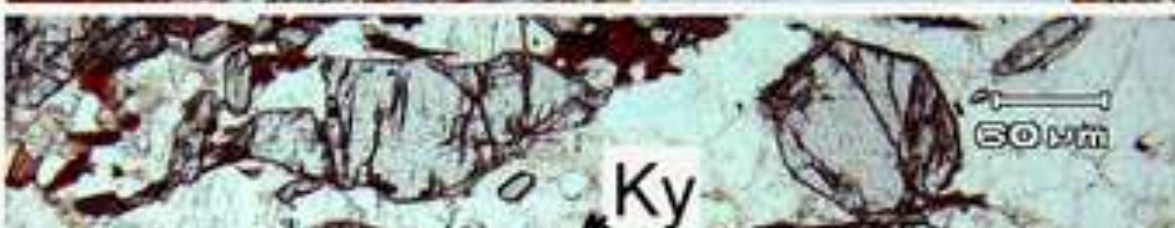

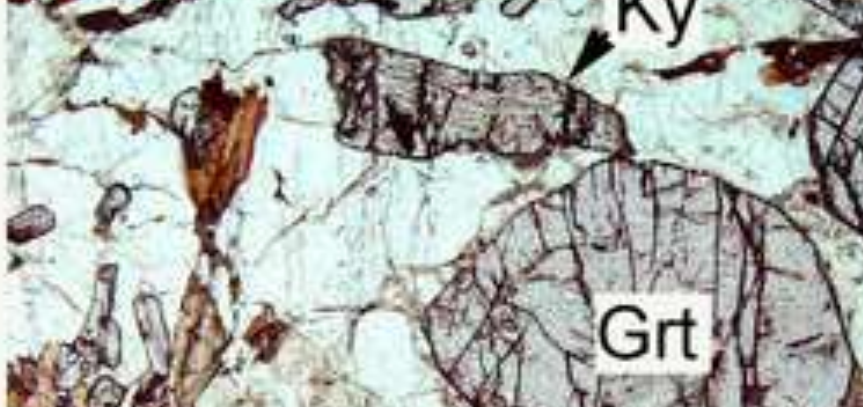

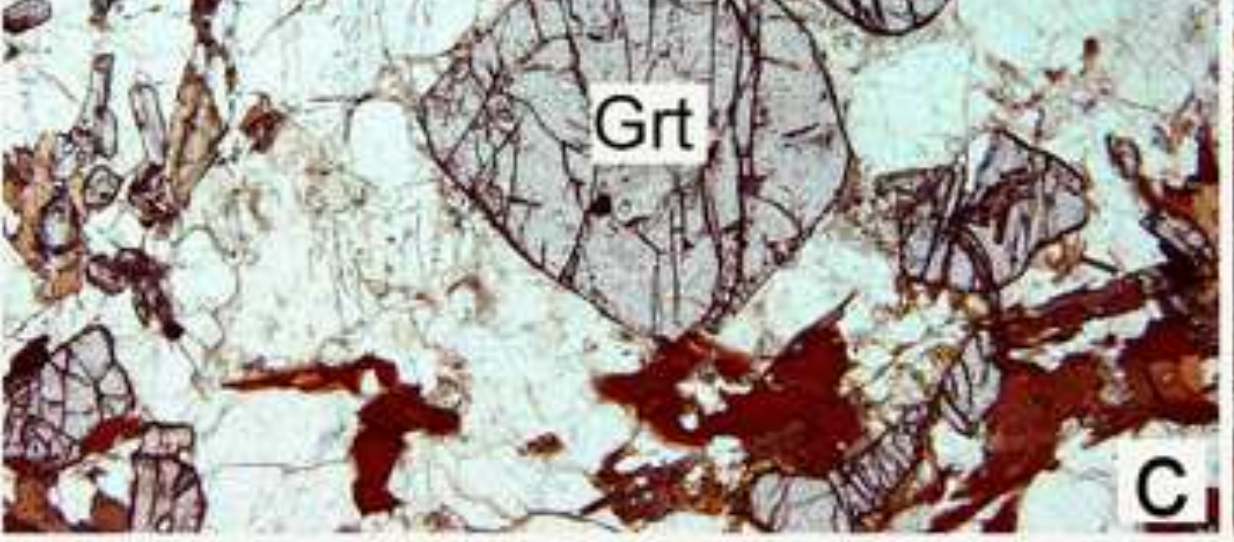

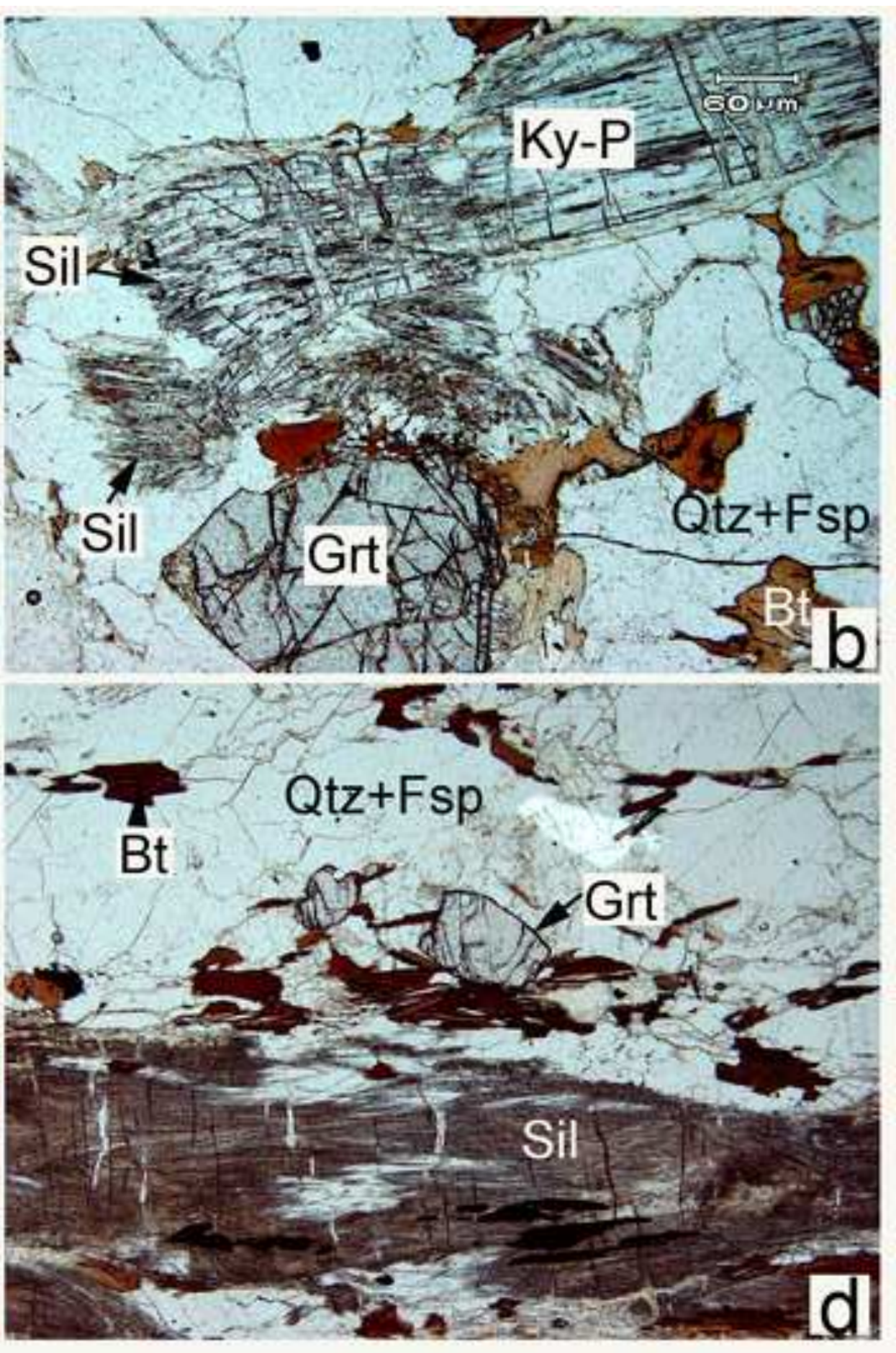




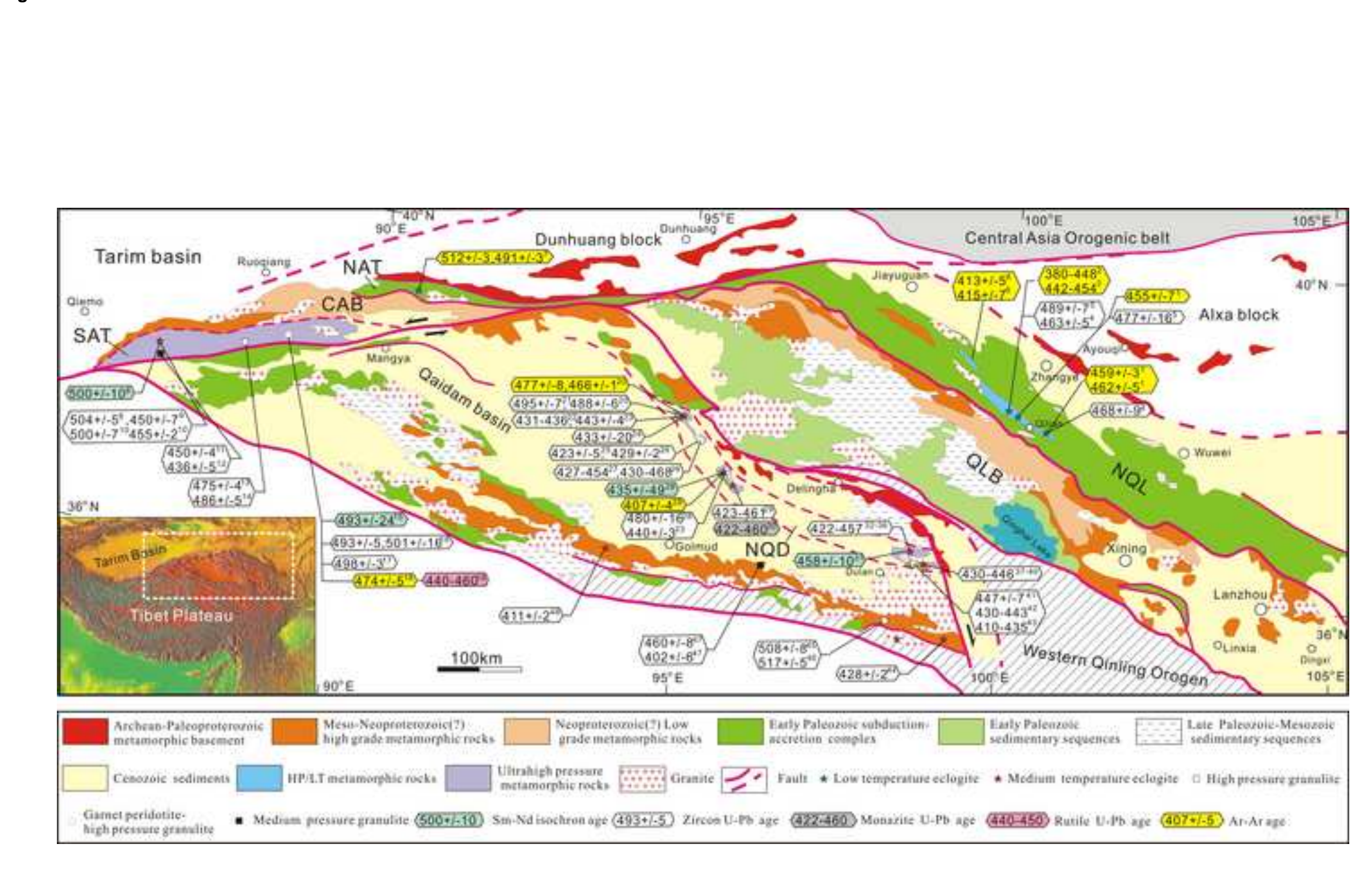

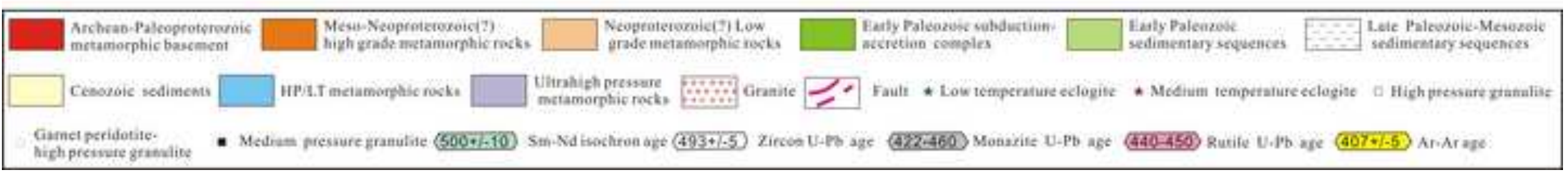




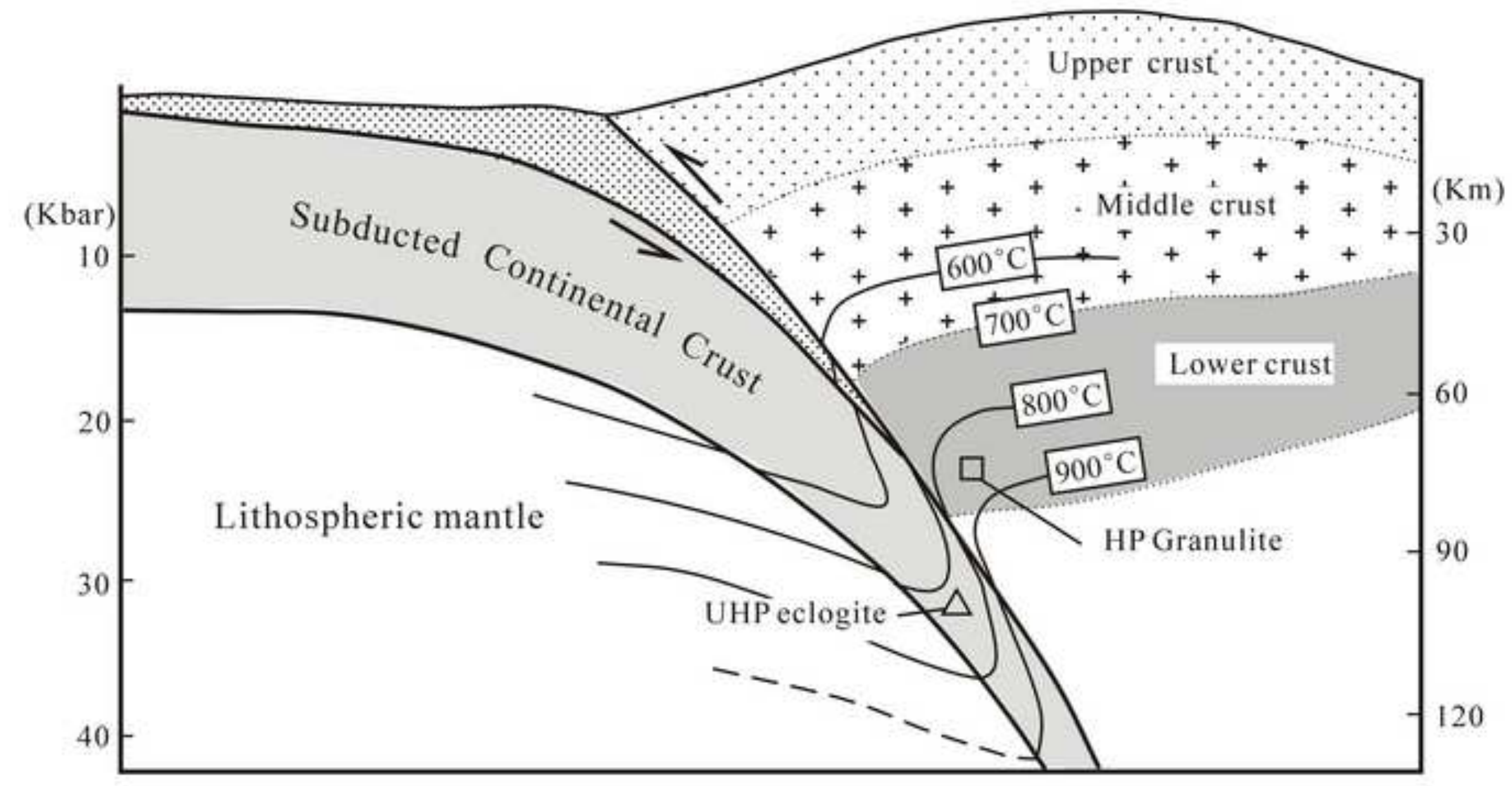


Table 1 Peak assemblage, $\mathrm{P}-\mathrm{T}$ estimates and $\mathrm{U}-\mathrm{Pb}$ dating data of mafic granulite and migmatitic metapelites

\begin{tabular}{|l|l|l|l|l|}
\hline Samples & Peak assemblages & Peak P-T conditions & U-Pb age & References \\
\hline 97A20-8 & Grt+Sil+Kf+Pl+Qtz & $723-806^{\circ} \mathrm{C}, 8 \mathrm{Kbar}$ & $448 \pm 7 \mathrm{Ma}$ & $\begin{array}{l}\text { Zhang J. et al., } \\
2011\end{array}$ \\
\hline 97A20-4 & Grt+Opx+Cpx \pm Amp-Pl-Qtz & $715-813^{\circ} \mathrm{C}, 8.6-10 \mathrm{Kbar}$ & $450 \pm 4 \mathrm{Ma}$ & $\begin{array}{l}\text { Zhang J. et al., } \\
2000\end{array}$ \\
\hline 97A20d & Grt+Sil+Kf $\pm \mathrm{Pl}+\mathrm{Bt}+\mathrm{Qtz}$ & & & $\begin{array}{l}\text { Zhang J. et al., } \\
\end{array}$ \\
& & & & 2000 \\
\hline AQ11-8-4.1 & Opx-Cpx-Pl-Qtz & & $436 \pm 4 \mathrm{Ma}$ & This study \\
\hline AQ11-8a & Grt+Sil+Kf+Pl+Bt+Qtz & $750-810^{\circ} \mathrm{C}, 6.5-8.0 \mathrm{Kbar}$ & $457 \pm 2 \mathrm{Ma}$ & This study \\
\hline AQ11-8h & Grt+Sil+Kf+Bt+Qtz & $760-805^{\circ} \mathrm{C}, 6.5-8.0 \mathrm{Kbar}$ & & This study \\
\hline AQ11-8i & Grt+Opx+Cpx $\pm \mathrm{Amp}+\mathrm{Pl}+\mathrm{Qtz}$ & $780-820^{\circ} \mathrm{C}, 7-8.1 \mathrm{Kbar}$ & & This study \\
\hline
\end{tabular}


Table 2 Dating data for Early Paleozoic metamorphism in the AQK orogenic system, Northern Tibet

\begin{tabular}{|c|c|c|c|c|c|c|}
\hline $\begin{array}{l}\text { Reference } \\
\text { No. }\end{array}$ & Sample locations & Rock type & Dating mineral and Method & Age & Explanation & References \\
\hline \multicolumn{7}{|c|}{ North Qilian } \\
\hline 1 & Baijingsi & blueschist & Phengite, $\mathrm{Ar}-\mathrm{Ar}$ & $\begin{array}{l}459 \pm 3 \mathrm{Ma} \\
462 \pm 3 \mathrm{Ma}\end{array}$ & Blueschist facies metamorphic age & Zhang J. et al., 1997 \\
\hline 1 & Wayaogou & blueschist & Glaucophane, $\mathrm{Ar}-\mathrm{Ar}$ & $455 \pm 7 \mathrm{Ma}$ & Blueschist facies metamorphic age & Zhang J. et al.,1997 \\
\hline 2 & Qingshuigou & blueschist & glaucophane/phengite, $\mathrm{Ar}-\mathrm{Ar}$ & $380-448 \mathrm{Ma}$ & $\begin{array}{l}\text { Blueschist facies metamorphic age or } \\
\text { cooling age }\end{array}$ & Liou et al., 1989 \\
\hline 3 & Qingshuigou & HP metasediment & Phengite, $\mathrm{Ar}-\mathrm{Ar}$ & $442-454$ & $\begin{array}{l}\text { Blueschist facies metamorphic age or } \\
\text { cooling age }\end{array}$ & Liu et al., 2006 \\
\hline 4 & Xiangzigou & eclogite & Zircon, U-Pb SHRIMP & $462 \pm 5 \mathrm{Ma}$ & Eclogite facies metamorphic age & Song et al., 2004 \\
\hline 4 & Baijingsi & eclogite & Zircon, U-Pb SHRIMP & $468 \pm 9 \mathrm{Ma}$ & Eclogite facies metamorphic age & Song et al., 2004 \\
\hline 5 & Wayaogou & eclogite & Zircon, U-Pb SHRIMP & $477 \pm 16 \mathrm{Ma}$ & Eclogite facies metamorphic age & Zhang J. et al., 2007b \\
\hline 5 & Xiangzigou & eclogite & Zircon, U-Pb SHRIMP & $489 \pm 7 \mathrm{Ma}$ & Eclogite facies metamorphic age & Zhang J. et al., 2007b \\
\hline \multirow[t]{2}{*}{6} & Jiugequan & $\begin{array}{l}\text { Lawsonite-bearing } \\
\text { blueschist }\end{array}$ & Glaucophane, $\mathrm{Ar}-\mathrm{Ar}$ & $413 \pm 5 \mathrm{Ma}$ & Blueschist facies metamorphic age & Lin et al., 2010 \\
\hline & Jiugequan & Epidote blueschist & Phengite, $\mathrm{Ar}-\mathrm{Ar}$ & $415 \pm 7 \mathrm{Ma}$ & Blueschist facies metamorphic age & Lin et al., 2010 \\
\hline \multicolumn{7}{|c|}{ North Altun } \\
\hline 7 & Hongliuquan & eclogite & Phengite, $\mathrm{Ar}-\mathrm{Ar}$ & $512 \pm 3 \mathrm{Ma}$ & Cooling age(?) & Zhang J. et al., 2007a \\
\hline 7 & Hongliuquan & blueschist & Paragonite, $\mathrm{Ar}-\mathrm{Ar}$ & $491 \pm 3 \mathrm{Ma}$ & Cooling age (?) & Zhang J. et al.,2007a \\
\hline \multicolumn{7}{|c|}{ South Altun } \\
\hline 8 & Jianggelesayi & eclogite & Zircon, U-Pb TIMS & $504 \pm 5 \mathrm{Ma}$ & UHP eclogite facies metamorphic age & Zhang J. et al., 2001a \\
\hline 8 & Jianggelesayi & eclogite & Sm-Nd Wr - Grt - Omp & $500 \pm 10 \mathrm{Ma}$ & UHP eclogite facies metamorphic age & Zhang J. et al., 2001a \\
\hline 9 & Jianggelesayi & $\begin{array}{l}\text { Paragneiss enclosing } \\
\text { eclogite }\end{array}$ & Zircon, U-Pb SHRIMP & $450 \pm 7 \mathrm{Ma}$ & Granulite facies overprinting age & $\begin{array}{c}\text { Zhang J. et al., } \\
\text { unpublished data }\end{array}$ \\
\hline 10 & Jianggelesayi & eclogite & Zircon, U-Pb LA-ICPMS & $500 \pm 7 \mathrm{Ma}$ & UHP eclogite metamorphic age & Liu et al., 2012 \\
\hline 10 & Jianggelesayi & eclogite & Zircon, U-Pb LA-ICPMS & $455 \pm 2 \mathrm{Ma}$ & Granulite facies overprinting age & Liu et al., 2012 \\
\hline 11 & Western Tula & $\begin{array}{l}\text { Grt-Opx-Cpx- } \\
\text { granulite }\end{array}$ & Zircon, U-Pb TIMS & $450 \pm 4 \mathrm{Ma}$ & MP granulite facies metamorphic age & Zhang J. et al., 2000 \\
\hline 12 & Western Tula & $\begin{array}{l}\text { Grt-Opx-Cpx-granul } \\
\text { ite }\end{array}$ & Zircon, U-Pb LA-ICPMS & $436 \pm 5 \mathrm{Ma}$ & MP granulite facies metamorphic age & This study \\
\hline
\end{tabular}




\begin{tabular}{|c|c|c|c|c|c|c|}
\hline 13 & Danshuiquan & Garnet pyroxenite & Zircon, U-Pb LA-ICPMS & $475 \pm 4 \mathrm{Ma}$ & HP granulite facies metamorphic age & Liu et al., 2009 \\
\hline 14 & Danshuiquan & Pelite granulite & Zircon, U-Pb LA-ICPMS & $486 \pm 5 \mathrm{Ma}$ & HP granulite facies metamorphic age & Cao et al., 2009 \\
\hline 15 & Bashiwake & Garnet pyroxenite & $\begin{array}{l}\text { Sm-Nd isochron } \\
(\mathrm{Wr}-\mathrm{Grt}-\mathrm{Cpx})\end{array}$ & $493 \pm 24 \mathrm{Ma}$ & HP granulite facies metamorphic age & Li et al., 2015 \\
\hline 16 & Bashiwake & HP felsic granulite & Zircon, U-Pb SHRIMP & $493 \pm 5 \mathrm{Ma}$ & HP granulite facies metamorphic age & Zhang J. et al., 2005c \\
\hline 16 & Bashiwake & Garnet peridotite & Zircon, U-Pb SHRIMP & $501 \pm 16 \mathrm{Ma}$ & HP granulite facies metamorphic age & Zhang J. et al., 2005c \\
\hline 17 & Bashiwake & Garnet peridotite & Zircon, U-Pb LA ICPMS & $498 \pm 3 \mathrm{Ma}$ & UHP metamorphic age & Wang et al., 2011 \\
\hline 18 & Bashiwake & HP mafic granulite & Amphibole, $\mathrm{Ar}-\mathrm{Ar}$ & $474 \pm 5 \mathrm{Ma}$ & Cooling age & $\begin{array}{l}\text { Zhang J. et al., } \\
\text { unpublished data }\end{array}$ \\
\hline 19 & Bashiwake & HP granulite & Rutile, U-Pb LA ICPMS & $440-460 \mathrm{Ma}$ & HP granulite overprinting age & Zhang J. et al., 2014 \\
\hline \multicolumn{7}{|c|}{ North Qaidam } \\
\hline 20 & Yuka & Eclogite & Ar-Ar (amphibole) & $478 \pm 8 \mathrm{Ma}$ & Cooling age (?) & Zhang J. et al., 2005a \\
\hline 20 & Yuka & Eclogite & $\operatorname{Ar}-\operatorname{Ar}($ phengite $)$ & $466 \pm 1 \mathrm{Ma}$ & Cooling age (?) & Zhang J. et al., 2005a \\
\hline 20 & Luofengpo & Eclogite & U-Pb TIMS (zircon) & $488 \pm 6 \mathrm{Ma}$ & Eclogite facies metamorphic age (?) & Zhang J et al., 2005a \\
\hline 21 & Yuka & Eclogite & U-Pb TIMS (zircon) & $495 \pm 7 \mathrm{Ma}$ & Eclogite facies metamorphic age (?) & Zhang J. et al., 2000 \\
\hline 22 & Yuka & Eclogite & LA ICPMS (zircon) & $\begin{array}{l}436 \pm 3 \mathrm{Ma} \\
431 \pm 4 \mathrm{Ma}\end{array}$ & Eclogite facies metamorphic age & Chen et al., 2009 \\
\hline 22 & Yuka & Paragneiss (schist) & LA ICPMS (zircon) & $\begin{array}{l}431 \pm 3 \mathrm{Ma} \\
432 \pm 19 \mathrm{Ma}\end{array}$ & Eclogite facies metamorphic age & Chen et al., 2009 \\
\hline 23 & Yuka & eclogite & LA ICPMS (zircon) & $443 \pm 4 \mathrm{Ma}$ & Eclogite facies metamorphic age & Xiong et al., 2012 \\
\hline 24 & Yuka & eclogite & SHRIMP(zircon) & $433 \pm 20 \mathrm{Ma}$ & Eclogite facies metamorphic age & Song et al., 2010 \\
\hline 25 & Lvliangshan Shenglikou & Garnet peridotite & U-Pb SHRIMP (zircon) & $423 \pm 5 \mathrm{Ma}$ & UHP metamorphic age & Song et al., 2005 \\
\hline 26 & Lvliangshan Shengyikou & Garnet peridotite & U-Pb ICPMS (zircon) & $429 \pm 2 \mathrm{Ma}$ & UHP metamorphic age & Xiong et al., 2011 \\
\hline 26 & Lvliangshan Shenglikou & Migmatitic gneiss & U-Pb ICPMS (zircon) & $468 \pm 4 \mathrm{Ma}$ & Prograde metamorphic age & Xiong et al., 2011 \\
\hline 26 & Lvliangshan Shenglihou & gneiss & U-Pb ICPMS (zircon) & $430 \pm 5 \mathrm{Ma}$ & UHP metamorphic age & Xiong et al., 2011 \\
\hline 27 & Lvliangshan Shenglikou & Felsic gneiss & U-Pb SHRIMP (zircon) & $454 \pm 6 \mathrm{Ma}$ & HP granulite facies metamorphic age & Zhang J. et al.,2008 \\
\hline 27 & Lvliangshan Shenglikou & Felsic gneiss & U-Pb SHRIMP (zircon) & $427 \pm 3 \mathrm{Ma}$ & $\begin{array}{l}\text { Medium pressure granulite facies } \\
\text { overprinting age }\end{array}$ & Zhang J. et al., 2008 \\
\hline 28 & Xitieshan & eclogite & Sm-Nd Wr-Grt-Omp & $435 \pm 49 \mathrm{Ma}$ & Cooling or late overprinting age & Zhang J. et al., 2005a \\
\hline 28 & Xitieshan & eclogite & U-Pb SHRIMP(zircon) & $480 \pm 16 \mathrm{Ma}$ & Eclogite facies metamorphic age & Zhang J. et al., 2005a \\
\hline 28 & Xitieshan & eclogite & $\mathrm{Ar}-\mathrm{Ar}$ (amphibole) & $409 \pm 1 \mathrm{Ma}$ & Cooling age & Zhang J. et al., 2005a \\
\hline 23 & Xitieshan & eclogite & LA ICPMS (zircon) & $440 \pm 3 \mathrm{Ma}$ & Eclogite facies metamorphic age & Xiong et al., 2012 \\
\hline
\end{tabular}




\begin{tabular}{|c|c|c|c|c|c|c|}
\hline 29 & Xitieshan & Paragneiss & U-Pb SHRIMP(zircon) & $451-461$ & HP granulite facies metamorphic age & Zhang J. et al., 2009a \\
\hline 29 & Xitieshan & Paragneiss & U-Pb SHRIMP(zircon) & $423-427$ & $\begin{array}{l}\text { Low-med pressure granulite facies } \\
\text { overprinting age }\end{array}$ & Zhang J. et al., 2009a \\
\hline 30 & Xitieshan & Paragneiss & U-Pb EMP(monazite) & $455-460$ & Prograde metamorphic age & Zhang C. et al., 2012 \\
\hline 30 & Xitieshan & Paragneiss & U-Pb EMP(monazite) & $422-425$ & Amphibole facies overprinting age & Zhang C. et al., 2012 \\
\hline 31 & North Dulan unit & eclogite & Sm-Nd Wr-Grt-Omp & $458 \pm 10 \mathrm{Ma}$ & Eclogite facies metamorphic age & Song et al., 2003 \\
\hline 32 & North Dulan unit & eclogite & U-Pb SHRIMP(zircon) & $457 \pm 7 \mathrm{Ma}$ & Eclogite facies metamorphic age & Song et al., 2006 \\
\hline 32 & North Dulan unit & eclogite & U-Pb SHRIMP(zircon) & $426 \pm 24 \mathrm{Ma}$ & Retrograde metamorphic age & Song et al., 2006 \\
\hline 33 & North Dulan unit & Coe-bearing gneiss & U-Pb SIMS (zircon) & $452 \pm 14 \mathrm{Ma}$ & UHP metamorphic age & Yang et al., 2005 \\
\hline 33 & North Dulan unit & Coe-bearing gneiss & U-Pb SIMS (zircon) & $419 \pm 14 \mathrm{Ma}$ & Retrograde metamorphic age & Yang et al., 2005 \\
\hline 34 & North Dulan unit & Coe-bearing gneiss & U-Pb SHRIMP (zircon) & $423 \pm 6 \mathrm{Ma}$ & UHP metamorphic age & Song et al., 2006 \\
\hline 34 & North Dulan unit & Coe-bearing gneiss & U-Pb SHRIMP (zircon) & $403 \pm 9 \mathrm{Ma}$ & Retrograde metamorphic age & Song et al., 2006 \\
\hline 35 & North Dulan unit & eclogite & U-Pb SHRIMP(zircon) & $422-449 \mathrm{Ma}$ & Eclogite facies metamorphic age & Mattinson et al., 2006 \\
\hline 36 & North Dulan unit & paragneiss & U-Pb SHRIMP(zircon) & $\begin{array}{l}426 \pm 4 \mathrm{Ma} \\
431 \pm 5 \mathrm{Ma}\end{array}$ & Eclogite facies metamorphic age & Mattinson et al., 2009 \\
\hline 37 & South Dulan unit & eclogite & U-Pb SHRIMP(zircon) & $445 \pm 7 \mathrm{Ma}$ & Eclogite facies metamorphic age & Zhang G. et al., 2008 \\
\hline 38 & South Dulan unit & Coe-bearing eclogite & U-Pb SHRIMP (zircon) & $440 \pm 6 \mathrm{Ma}$ & UHP metamorphic age & Zhang G. et al., 2009a \\
\hline 39 & South Dulan unit & Coe-bearing eclogite & U-Pb SHRIMP (zircon) & 430-446Ма & UHP metamorphic age & Zhang J. et al., 2010 \\
\hline 40 & South Dulan unit & Coe-bearing eclogite & U-Pb SHRIMP (zircon) & $440 \pm 6 \mathrm{Ma}$ & UHP metamorphic age & Yu et al., 2013 \\
\hline 40 & South Dulan unit & Gneiss & U-Pb ICPMS (zircon) & 438-439Ma & Eclogite facies metamorphic age & Yu et al., 2013 \\
\hline 41 & South Dulan unit & HP mafic granulite & U-Pb ICPMS (zircon) & $447 \pm 7 \mathrm{Ma}$ & HP granulite facies metamorphic age & Yu et al., 2010 \\
\hline 42 & South Dulan unit & HP granulite & $\begin{array}{l}\mathrm{U}-\mathrm{Pb} \\
\text { (zircon) }\end{array}$ & 430-443Ма & HP granulite facies metamorphic age & Yu et al., 2014 \\
\hline 43 & South Dulan unit & HP mafic granulite & U-Pb SHRIMP (zircon) & $411-435$ & HP granulite facies metamorphic age & Song et al., 2014 \\
\hline \multicolumn{7}{|c|}{ North Kunlun } \\
\hline 44 & Wenquan & eclogite & U-Pb SHRIMP (zircon) & $428 \pm 2 \mathrm{Ma}$ & Eclogite facies metamorphic age & Meng et al., 2013 \\
\hline 45 & Qingshuiquan & Mafic granulite & U-Pb SHRIMP (zircon) & $508 \pm 8 \mathrm{Ma}$ & Granulite facies metamorphic age & Li et al., 2007 \\
\hline 46 & Qingshuiquan & Mafic granulite & U-Pb SHRIMP (zircon) & $517 \pm 5 \mathrm{Ma}$ & Granulite facies metamorphic age & Chen et al.,2003 \\
\hline 47 & Nuomuhong & Mafic granulite & U-Pb SHRIMP (zircon) & $460 \pm 8 \mathrm{Ma}$ & Granulite facies metamorphic age & Zhang J. et al.,2003 \\
\hline 47 & Nuomuhong & Migmatitic gneiss & U-Pb SHRIMP (zircon) & $402 \pm 6 \mathrm{Ma}$ & Anatectic age & Zhang J. et al., 2003 \\
\hline 48 & Xiarihamu & Retrograde eclogite & U-Pb LA-ICPMS (zircon) & $411 \pm 2 \mathrm{Ma}$ & Eclogite facies metamorphic age(?) & Qi et al., 2014 \\
\hline
\end{tabular}

